\title{
Christian Pastors and Alleged Child Witches in Kinshasa, DRC
}

\author{
Robert J. Priest ${ }^{1}$, Abel Ngolo ${ }^{2}$ and Timothy Stabell ${ }^{3}$
}

\begin{abstract}
Against earlier predictions, witch accusations are proliferating and flourishing in many modern, urban, and Christian environments. And they are taking new forms. One dramatic change involves who is accused, with children now often the prime suspects when misfortunes occur. Another dramatic change relates to who is consulted when witch suspicions are present. Rather than non-Christian diviners or traditional healers, many now consult Christian pastors and prophets for help in identifying witches and dealing with them. Based on a survey of 713 pastoral leaders in Kinshasa from all major church traditions, and on supplemental qualitative research, this report 1) explores the profile of accused children, 2) identifies what these children are accused of, 3) identifies what sorts of evidence are used to establish the guilt of the accused child, and 4) considers the consequences to the child of being labeled a witch. Furthermore, this report explores what it is that church leaders believe, teach, and practice in relationship to child-witch allegations-considering the role of church tradition and theological education on their patterns of understanding and engagement. Specifically, we identify and examine two broad paradigms widely present in Kinshasa churches-a "witch diagnosis and deliverance paradigm" and a "child protection paradigm." We consider some grassroots strategies of transformative engagement engaged in by l'Équipe Pastorale auprès des Enfants en Détresse [EPED] leaders, and end by inviting African theological and pastoral leaders into a conversation about the impact of theological understandings, congregational discourses, spiritual disciplines, and pastoral practices on the well-being and flourishing of vulnerable children.
\end{abstract}

\section{Chapter 1: Introduction to the Study ${ }^{4}$}

\subsection{Introduction}

In recent decades, human rights activists and organizations have expressed alarm at how frequently children in various regions of the world are accused of being dangerous witches and treated as such. In prior eras witch accusations customarily targeted older adults. Children sometimes appeared in these earlier accounts, but usually only as victims of witchcraft or as witnesses

\footnotetext{
'At the time of research Dr. Robert Priest was G. W. Aldeen Prof. of International Studies and Professor of Anthropology and Mission at Trinity Evangelical Divinity School. At the time of publication he is Professor of Anthropology at Taylor University.

"Révérend Abel Ngolo is the Secrétaire général-représentant legal of l'Équipe Pastorale auprès des Enfants en Détresse (EPED).

Rev. Dr. Timothy Stabell is a former missionary in the DRC (where he also grew up as the child of missionaries). He currently serves as a pastor and as an adjunct professor both at Shalom University of Bunia, DRC and also at Briercrest College and Seminary.

"We wish to express deep appreciation to the twenty individuals who carried out this survey research: Jean Alengo, Jacques Manzita, Néhémie Mukandama, John Kabunda, Abraham Fundasili, Médard Limboto, André Nshole, Sylvie Nkolomoni, Angèle Kimfuta, Rodin Mukwama, Simsas Siwakio, George Matungulu, Beya Bantu, Marcellin Omango, Kalubi Muneme, Roger Lambi, Jean Kimbeni, Valetin Ngiama, Faustin Tshiebue, Bienvenu Banani. Without their commitment, dedication and hard work on behalf of the street children of Kinshasa and on behalf of this research, this research would never have been completed. They are truly heroes in the fight to protect Kinshasa's children. We also wish to thank the 713 pastoral leaders who took time to answer each question of the survey. Funding for the research was received from the Carl F. H. Henry Center for Theological Understanding of Trinity Evangelical Divinity School and from Stop Child Witch Accusations. Dr. Robert Priest and Rev. Abel Ngolo served as the primary research directors.
} 
testifying against older adults. Children were infrequently the ones accused. $^{5}$

Against all expectations, modernity has not led to the demise of witch accusations and retaliatory practices, but to their resurgence and reformulation. Revised understandings of witchcraft that have recently emerged increasingly focus suspicions on children. ${ }^{6}$ This development has been observed in the Democratic Republic of the Congo, Angola, Benin, the Central African Republic, Gabon, Malawi, Nigeria, Sierra Leone, Tanzania, and in immigrant communities of Europe. Kinshasa is an influential epicenter ${ }^{7}$ of the new paradigm.

Furthermore, in a pre-Christian past, people characteristically brought their suspicions about witchcraft to the attention of traditional healers, diviners, and shamans, and depended on them to authoritatively interpret and address misfortunes understood as caused by witches. But scholars who study recent developments related to child witchcraft highlight rather the current trusted role of Christian pastors, prophets, apostles, intercessors, and other church leaders in authoritatively addressing witchcraft suspicions and accusations. ${ }^{8}$

And yet most scholars who have researched child witch accusations, at best focus only a small part of their research on the church leaders themselves. By contrast, this report, and the research on which it is based, focuses centrally on the experiences, understandings, and practices of church leaders in Kinshasa as they pertain to child-witch accusations.

\subsection{Witchcraft Accusations and Tragedies in Kinshasa}

Kinshasa, with a population of over eleven million", is the third-largest city in Africa (after Lagos and Cairo). A significant proportion of residents experience underemployment, poverty, ${ }^{10}$ family conflicts and

${ }^{5}$ Only rarely have anthropologists found traditional societies that regularly accused children of causing the misfortune of others through witchcraft (for such exceptional cases, see Brain 1970, Honigmann 1989, Santos-Granero 2002, 2004, and Yengo 2008). In discussions (May 3-26, 2017 Kinshasa) with elderly informants from different Congolese ethnic groups who were drawing on their memories of village childhoods from decades earlier, some denied that in their group (Luba, Ngombe) children were ever accused of witchcraft. Others reported, that while rare, children in their ethnic group (Bakongo, Kanioka, Kituba, Mongo, Songe, Tetela) were occasionally accused of witchcraft, usually under the logic that witchcraft had been transmitted to them from an older witch in their family. So while the idea that children could be witches is not completely unprecedented in the DRC, the current central focus in Kinshasa on children as prime suspects, is new.

${ }^{6}$ Adinkrah 2011; Ballet, Lallau \& Dumbi 2019; Barker 2016; Barry 1998; Bartholomew 2015; Bastian 2001; Biehl 2013; Cahn 2006; Chilimampunga and Thindwa 2012; Cimpric 2010; De Boeck 2004, 2005, 2006, 2009; De Boeck and Honwa 2005; De Boeck and Plissart 2003, 2004; D'Haeyer 2004; Foxcraft 2007; Geschiere 1980; Hanson and Ruggiero 2013; La Fontaine 2009, 2012; Madungu Tumwaka 2002; Mayneri 2017; Molina 2005; Nwadinobi 2008; Oien 2006; Onuzulike 2013; Pereira 2011; Phiri 2009; Pirot 2004; Pull 2009; Ranger 2007; Riedel 2012; Snow 2017; Stobart 2006, 2009; Tabu 2008; Tate and Stauss 2006; Tonda 2008; Van der Meer 2013; Yengo 2008. Interestingly there are parallels with witch accusations in European history. Towards the end of the European witch trials, during the late seventeenth and early eighteenth centuries, many European children were prosecuted as witches (Henningsen 1996; Roper 2000; Walinski-Kiehl 1996; Willumsen 2013). According to Levack (2006a, 154) "child witches figured prominently in the last great witch hunts in Sweden, Augsburg and Austria." Levack (154-155) believes the increased prosecution of children contributed to "a general doubt that those accused were guilty" and thus "played a significant role in the decline and end of witchcraft" in Europe.

"La Fontaine $(2009,121)$ reports that the Democratic Republic of the Congo was the "earliest recorded site" of the recent epidemic of child witch accusations, with diasporas from the DRC carrying child-witch beliefs, accusations, and patterns of response with them to Europe and elsewhere. De Boeck (2009, 132-133) says the "production of child witchcraft" spread from Kinshasa across "Congo and indeed Africa and beyond" on an "unprecedented scale." He identifies Congolese diasporas in Africa and Europe as transmitting the "production of child witchcraft" largely through their Pentecostal churches and networks. De Pereira $(2011,203-205)$ reports that Angola's explosion of child witch accusations emerged first among Bakongo immigrants from the DRC. And while Stobart (2006, 12) documents child-witch accusations in the UK among immigrants with diverse backgrounds (from Angola, Burundi, Ghana, Ivory Coast, Mauritius, Nigeria, Tanzania, as well as from the Carribean and S. Asia), the largest number (over a third) were from the DRC.

${ }^{8}$ Adinkrah 2011; Ballet, Lallau \& Dumbi 2019; Barker 2016; Blanes 2017; Bussien et. al. 2011; Cahn 2006; Chilimampunga and Thindwa 2012; Cimpric 2010; Cohan 2011; De Boeck 2004, 2009; Foxcraft 2009, 2014; Groce and McGeown 2013; Hanson \& Ruggiero 2013; La Fontaine 2009; Mayneri 2017; Molina 2005; Nwadinobi 2008; Pearson 2009; Pereira 2011; Pull 2009; Pype 2017; Riedel 2012; Schnoebelen 2009; Snow 2017; Stobart 2009; Tate and Stauss 2006; Tonda 2008; Yengo 2008.

Populations of 150 Largest Cities in the World. World Atlas. 17 January 2018. Retrieved 18 November 2019 [https://www.worldatlas.com/citypops.htm].

${ }^{10}$ Ballet, Lallau and Dumbi (2019) report on research by Tollens (2003) indicating that half of Kinshasa's population eats only one meal a day, with a quarter of the population eating less than one meal per day.

Priest, Ngolo, and Stabell, Christian Pastors and Alleged Child Witches 
breakups, medical crises, high levels of violence, and elevated emotional distress. Government infrastructure supports (electricity, water, education, sanitation, police protection, medical care, good roads) are weak. Fertility rates are high. Parents and other caretakers often struggle to adequately fulfill parental obligations to provide their children with food and education.

It is against this backdrop that thousands of children in Kinshasa are accused of having caused, through witchcraft, the misfortunes (poverty, infertility, sickness, and death) experienced by family members. Prior research ${ }^{11}$ suggests the following profile of children most likely to be accused of being malign witches.

- Children living in a home with multiple young dependents, with unemployed or underemployed caregivers, and with an absence of one or both biological parents. Especially likely to be accused were orphans living with extended relatives and children living with one parent and one stepparent in a reconstituted family. ${ }^{12}$

- Children with physical disabilities and other healthrelated attributes (epilepsy, scabies, red eyes, thinness, pot-bellied) or psychological disorders (withdrawn, depressed).

- Children with unusual behaviors (talking to self, averted gaze, nightmares, bedwetting, sleepwalking, sleep-talking) or disapproved characteristics (stubbornness, aggression, disobedience, laziness, theft).

The consequences of being labeled a witch are serious. In their own homes, accused children experience neglect and physical abuse. Often family members take them to one of the "more than 2,000 churches" in Kinshasa that practice "deliverance" for witchcraft (Tate and Stauss 2006, 3) and where the children are sometimes subjected to prolonged periods without food or water, combined with a variety of cleansing practices such as forced ingestion of purgatives, removal of body hair, or even being burned with fire. Furthermore, as feared witches, many children are driven from their homes to the street. Experts have estimated that perhaps $60 \%$ of Kinshasa's twenty thousand or more street children are on the street, in part, as a result of having been labeled witches. ${ }^{13}$ On the street, such children experience violence, poverty, and hunger as well as theft, exploitation, and physical or sexual abuse from a wide variety of actors, ranging from older street youth to police (Tate and Stauss 2006, 15-44).

\subsection{First-Hand Account: "It started with the death of our sister!"}

Perhaps the easiest way for readers to gain an initial sense of the dynamics of child witch accusations is to read a first-hand account. In the following narrative, ${ }^{14}$ one observes many of the most common elements in such cases: 1) people's effort to make sense of tragedy, 2) characteristic parental and family dynamics, and 3) the central role, and varying approaches, of church leaders in addressing witchcraft concerns.

\section{Sylvain Mbaki's Childhood Story}

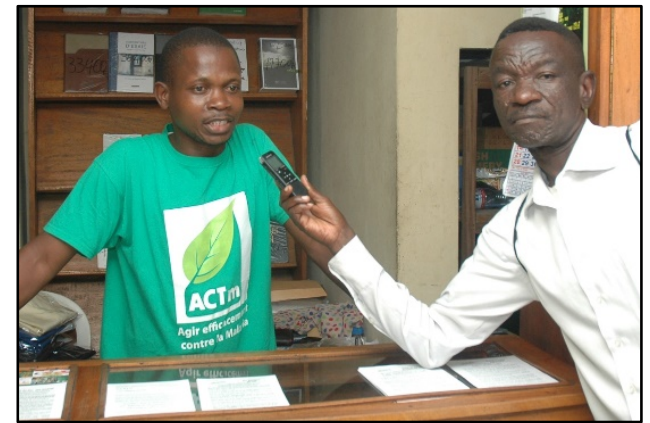

Sylvain Mbaki, a bookshop manager, tells his story

to Mr. André Nshole, EPED Coordinator of Project Evaluation and Follow-up.

It started with the death of our sister! We were a family of five children. My mom brought my brother and me linto the family], and my step-dad also had two children that he brought in. My father was deceased. So the death of our sister is what started it.

"See Ballet, Lallau, and Dumbi 2019, 132-133; Cimpric 2010, 16-17; Molina 2005; Pereira 2011, 188-190; Snow 2017, 5; Stobart 2006, 19-20).

${ }^{12}$ Ballet et al. $(2019,132)$ reported that in their sample of 31 accused children, $68 \%$ were in reconstituted families, and that children living with both their biological parents were less likely to be accused than those living with at least one non-biological parent. In Madungu Tumwaka's (2002) survey of 350 children accused of being witches, 80\% "were living in families where the head of household was not a biological parent” (cited in Ballet et al., 132). See also De Boeck 2009, 136).

${ }^{13}$ Schnoebelin 2009, 14-15. Estimates of Kinshasa's street children range from a low of twenty or twenty-five thousand (Pirot 2004; Ballet 2019, 126, Schnoebelin 2009, 14-15), to as high as fifty (De Boeck (2009, 130) or even a hundred thousand (Cahn 2006, 414).

"Recorded May 12, 2017 in Kinshasa. 
We had to find the cause of her death. She died December $25^{h}$, and her body was buried on the $30^{h}$. It was the holiday season, and in our culture, we need to eat during this time. But mom and dad said, "No, we need to find the reason!" So we started attending churches where they prophesy, to seek who was the cause of our sister's death.

I was in the choir in a Protestant church. But my dad went to a church of Molimo-where people prophesy. And since people in my church don't prophesy, my dad said we were hiding our witchcraft. He wanted the whole family to follow him. My mom said I should follow my dad to avoid problems. But I refused.

The economic life at home dropped. Eating became difficult, and out of all the family members, the only person who lost weight was me. So my stepdad started to think that was suspicious. "How come only you are losing weight?" One day he asked me: "When do you sleep? Do you dream? Do you see things." I replied: "I don't see anything. I sleep like everyone. I dream like everyone."

But he told me, "At the church where we pray the prophetess told the whole family that "there is a child in your house that is losing weight continuously. I invite you to bring him so that I can tell you what is wrong." So we went on Wednesday evening. But when the Prophetess saw me, she said, "The spirit doesn't work well during the Passion-the season when Christ suffered. So I can't prophesy now. Come back after Easter:"

My dad did not want to wait, so he brought me to another church on Saturday. They spread us out under the sun. There were a lot of children there, on our knees, and the "mamas" were prophesying over each one. We needed to wait for our turn. I was on my knees from 10 AM to 4 PM, under the sun. But the ceremony closed before our turn came. We went home. The next Saturday our family went very early hoping to be the first they would prophesy over. My family placed me in front because I was the suspect. But when they finally got to me, my dad had already left. So my mom explained to the prophesying mamas, "here is my child. He keeps losing weight. We want to know what is wrong with him." The prophetess said, "Take him first to the hospital. Maybe they will know what is wrong:" So when we got home, my mom explained that the prophetess said I should be taken to the hospital. My dad did not agree. He said, "Sometimes witches leave their witchcraft at the door of the church, so the prophetess doesn't see it. We need to go back again. I need to be there." So a third Saturday our whole family returned, very early. The prophetess told my mom "your child has been bewitched from when he was in the womb by his father's father." My mom screamed, "I don't believe it!" She argued, "I never met my father-in-law. He was already deceased. Maybe you mean it is my current husband's father!" But the prophetess denied that. So they argued. But my dad said, "Yes, this child is a witch." And when we went home, he told all his friends, "This child is a witch." When my friends asked if it was true, I replied: "I don't know." My dad began pressuring my mom to take me to "people of the spirits" to remove the witchcraft. But my mom did not want to. We stayed like that until the $2^{\text {d }}$ of July, the day I picked up my report card for 10th grade, a Wednesday I think. The problem exploded at home that night. My dad started blaming my mom, "Ever since it was prophesied that your child is a witch, you haven't done anything. You're always home. You leave him just as he is. Soon I will get angry, and decide on my own!"

So my dad found another church and told the whole household to attend so that our home would have deliverance. Life at home was very difficult. We were living off my mom selling foufou. My dad's job was not working out, so it was very hard. On Wednesday, without eating, while fasting, we went to that church. We found an unfinished church with a "Father" [pastorl and some kids. When we came in, they prayed for us, they sang; they prophesied. As I told you, my dad had two children, two daughters that he had before getting married to my mom. The prophets there said, "Mom and dad, both of your daughters here have been witches for a long time. Your oldest girl here is getting married soon, in the night, in the witch's world. Soon she will be married. So we need to cut their hair." So they cut off the hair of both girls. They covered them with white sheets and started to pray and prophesy, even hitting them, saying "Why don't you want to leave witchcraft? It's blocking your dad."

But since I was the one my dad suspected, he interrupted and said, "but look at this young man here. Look at him. We were told he is a witch." They replied, "No, we viewed him in the back area, and he was a little blurry. But we did a ceremony with water, and the blur went away." That is how we cleansed ourselves. They gave us each a bucket of salt and powder mixed in water to wash. They said this took off the "blur" they saw on me.

We were there for four days. The fifth day was to be the day of deliverance, so the whole household had to be present-while fasting. Dad went early with his daughters. We got there a little late with my mom. They gave us a potion [to drink/ and told us this would enable us to purge ourselves. I was suspicious and said, "How can I drink this kind of water?" So I refused. Mom also refused. The prophets said to my dad, "Don't look for solutions with your wife and her 
children because they are the ones causing your trouble. See how we are trying to deliver you, but they refuse to be cleansed." His daughters complained, "Why is mom refusing to take [the potionl? We are taking it." "Ah," Imom said], "You think this water will deliver us!?" The girls reported to their dad /what my mom said]. When we got home, dad was angry. There was a big fight, and dad kicked me out of our home.

I was going to travel to Kimbansek to see if I could stay with my great aunt and uncle. But a brother from my church said, "Don't leave. We need you in our choir. Stay." So I lived with this brother for two years, while I completed $7^{h}$ grade (premeire secondaire) and $8^{h}$ grade (deuxieme secondaire). I told people at my church the situation, and they supported me in prayer. They rejected the accusations against me. If it were only up to me, I would have accepted everything people told me. But when pastors told me, "They are false prophets!" this gave me the boldness to not believe everything I was told.

Mom loved me a lot. When dad kicked me out, there was no peace at home, so dad divorced her. But dad didn't have any money, and the children started to lose weight.

Eventually, he left for the village. My mom came to visit and learned what had happened. She took us all in, including my brothers and sisters from my dad's house, because my dad had become irresponsible. We moved to Mwana, in the south of the Congo. She put us all in school. I even went to study theology. My mom paid for it. Until January, when my mom died.

Later, I helped my father financially and took care of him in the hospital. He never asked for forgiveness, but his attitude toward me changed.

Witch suspicions and accusations in the above account, as in virtually all such Kinshasa accounts, begin with an effort to make sense of mysterious misfortunes. The Christmas day death of Sylvain Mbaki's sister and his family's perpetual economic misfortunes demanded an explanation, a "reason." But while cultures vary widely in their assumptions about how to explain misfortune, historically and globally the single most common causal ontology, according to anthropologist Richard Shweder, is an "interpersonal" causal ontology-an assumption that misfortunes are caused by other malignant people acting to cause harm through mysterious power. ${ }^{15}$ In short, interpersonal causal ontologies convert the "why" question into a "who" question. Thus Sylvain's family declared, "We need to find the reason! So we started attending churches where they prophecy to seek who was the cause of our sister's death.”

In the above account, we also find a reconstituted family with multiple dependents in which each child lived with one biological parent and one step-parent, with the non-biological parent being the principal accuser, the one seeking confirmation of the witchcraft charge against a step-child. Rather than asking nonChristian traditional diviners to authoritatively identify the witch, this family (as with many in Kinshasa today), sought help from Christian churches that offer ministries claiming the power to identify child-witches, and to cleanse them of witchcraft.

Finally, this account illustrates the central roles and varying approaches of churches in addressing witchcraft suspicions, all within the context of a competitive religious market. Some, such as members of Sylvain's Protestant church, defended him against witchcraft charges, encouraged him to disbelieve the charges, and took him in when his family expelled him. Other churches and their leaders offered specialized ministries involving special understandings and powers marketed to parents who suspect their children of being witches. And yet, even these churches, as the account makes clear, do not uniformly endorse parental suspicions. Thus one prophetess advised them to take their son to the hospital for a diagnosis of his problem. But the step-father was actively shopping for a church that would endorse his suspicions, either to cleanse his step-son of witchcraft or to endorse his justification for expelling the boy from home. In such a competitive religious market, churches whose leaders claim the knowledge and power needed for identifying and dealing with witches hold a special attraction for many.

\subsection{The Meaning of "Witch" (and "Witchcraft")}

While English speakers will sometimes assume that there is a single clear meaning in the term "witch" or "witchcraft," in fact, English speakers use these terms with discordant meanings. Just as the word "football" can be confusing in some conversations because Americans associate "football" with a completely different sport than everyone else does (Americans refer to what others call "football" as "soccer"), the word "witch" can likewise confuse when conversation partners have completely different referents in mind when they use the term. It is possible for two parties to use the same word, and to assume that effective communication is happening while failing to recognize that each party assumes different meanings. Thus it is

\footnotetext{
${ }^{15}$ Shweder (2003) provides a systematic summary of a variety of causal ontologies present in different cultures (ranging from interpersonal causal ontologies, to moral, biomedical, astrophysical, etc.) and ranking them by relative frequency.
} 
important to specify intended meanings.

In this report, the English term "witch" (or the French "sorcier/sorcière") is not intended to reflect the full range of contemporary American or European meanings, but instead to reflect core meanings long present in the vocabulary of Congolese languages. An American or European practitioner of the neopagan religion Wicca will call herself a "witch" or "sorcière," and may affirm a Wiccan ethic of "Do no harm." But such a neopagan, feminist, New Age religiosity is an entirely different sort of thing from what is being considered in this paper when children are labeled "sorcier/sorcière" or "witch." ${ }^{16}$ Across Congolese languages, one finds the idea that there is a named category of person that is malevolent and powerful, the mysterious cause of misfortune and death in those around them. That is, the essence of the identity is the notion of an evil person who harms others. Each language examined has a term for such a malign person (a "witch), a related term for their practice or power ("witchcraft"), and a third term, a verb, to describe their harmful act ("to bewitch"). In Lingala, for example, there is the ndoki (the witch), kindoki (witchcraft), and koloka (to bewitch). In Tshiluba the witch is muloji, witchcraft is buloji, and "to bewitch" is kuloa. For further examples from Congolese languages see footnote. ${ }^{17}$

Most contemporary Americans and Europeans have never had neighbors, relatives, or colleagues attribute their misfortune to other persons thought to have harmed them through witchcraft. Even when Americans and Europeans experience tragic mis- fortunes and setbacks, most have never had neighbors, relatives, or colleagues suggest to them that some nearby malignant person is to blame for the misfortune, caused through witchcraft. The result is that Americans and Europeans seldom use the term "witch" with the specificity implied by words like ndoki, uchawi, or mulöi. Indeed, they will often apply the words "witch" or "witchcraft" to phenomena that Congolese languages linguistically differentiate from these concepts.

Congolese societies historically had a variety of named professional diviners, healers, and other magico-religious practitioners who publicly announced their identities and their professional services-with the stated goal of assisting clients. These were linguistically distinct from what we, in this report, are translating as "witch." The Lingala nganga (traditional healer) is an altogether different identity from the Lingala ndoki (the witch). The Kisonge "witch" (ndoshi) is said to exercise the power of "witchcraft" (butshi) and acts "to bewitch" (kulowa) others. But the Kisonge shalubuku ("diviner") is a completely different identity from the ndoshi (witch). The shalubuku (diviner) exercises the power of lubuku ("divination"), not the power of butschi ("witchcraft"), and acts "to divine" (kubuku) needed information, not "to bewitch" (kulowa) anyone. In none of the Congolese languages examined, is the normal role, power, and activity of traditional diviners and healers described using the same indigenous terms translated here as "witch," "witchcraft," or "to bewitch." Rather, each Congolese language examined (see footnote) differentiated lexically the "witch" identity from the "traditional healer/shaman/diviner" identity.

${ }^{16}$ For a helpful comparison of terminology used in "first-world Neopaganism" with terminology common to Africa, see Hayes 1995.

${ }^{17}$ Words for Witch, Witchcraft, and "To Bewitch."

\begin{tabular}{llll}
\hline Language & witch & witchcraft & to bewitch \\
\hline Kikongo & ndoki & kindoki & kuloka \\
Kanioka & muloj & buloj & kulow \\
Kisonge & ndoshi & butshi & kulowa \\
Lingala & ndoki & kindoki & koloka \\
Lomongo & boloki & iloka & oloka \\
Ngbaka & wi tunumo & tunumo & danga \\
Ngombe & mwemba & demba & boako \\
Swahili & mulozi, mchawi & ulozi, uchawi & kuloga, kuchawi \\
Teke & moloo & ndoo & oloo \\
Tetela & doka & doka & tocha \\
Tshiluba & muloji & buloji & kuloa \\
\hline
\end{tabular}

${ }^{18}$ Distinction between Diviners/Shamans/Healers vs Witches in Congolese Languages

\begin{tabular}{lll}
\hline Language & Diviner, Shaman, Healer, Feticheur & Witch, Sorcier/Sorcière \\
\hline Kikongo (of Bas-Congo) & nganga-nkisi, umonanga-mambu, ngunza, n'sadisi & ndoki \\
Kanioka & nganga, nganga buk, lubuk & muloj \\
Kisonge & nganga, shalubuku & ndoshi \\
Kituba & nganga-kisi, nganga-ngombo & ndoki \\
Lingala & nganga-kisi, nganga & ndoki, ntshor \\
Lomongo & nkanga, akunda & boloki
\end{tabular}

Priest, Ngolo, and Stabell, Christian Pastors and Alleged Child Witches 
In this report, we follow anthropological convention in attempting to retain the above distinction in our wording. We translate the identities of traditional magico-religious professionals who publically offer their special powers to assist clients as "traditional healers," "shamans," or "diviners." But we reserve the English words "witch" and "witchcraft" for the identities of those thought to be the malign secret cause of misfortune in the lives of others, misfortunes ranging from poverty to bad luck, impotence, infertility, sickness, and death.

And yet it is not uncommon for English speakers to call shamans, traditional healers, and diviners "witch doctors" and to call their activities "witchcraft"-wording that anthropologists uniformly reject. That is, popular English-language usage of "witch" or "witchcraft" does not easily lend itself to precise translation of concepts from other languages. Thus when discussing the woman from Endor that King Saul consulted (I Samuel 28), English speakers will routinely refer to her as a "witch," and French speakers will refer to her as a "sorcière." But, to be anthropologically accurate, she is a diviner. In Kisonge terms, she is a shalubuku (a diviner), not a ndoshi (a witch). There is no biblical evidence that anyone attributed their misfortunes to this woman. Similarly, when the dictionary at the back of the TNIV Bible (published by Zondervan) defines "witchcraft" (p. 1167) as "the practice of predicting the future by interpreting omens, examining the livers of sacrificed animals, and contacting the dead-among other techniques" (1167), this is extremely confusing since all of these practices are the practices of diviners, shamans, and traditional healers, not of witches. And yet, this was how the English word "witchcraft" was defined by the American publishers of this Bible. A key point to bear in mind is that most Europeans and Americans have minimal, if any, first-hand exposure to witch-accusation discourses, and thus typically use words like "sorcier" or "witch" and "witchcraft" in imprecise and ambiguous ways that confuse and conflate two culturally distinct sorts of identity.

Another complication is that the term "witch" in popular English usage often refers only to females. And yet the majority of indigenous words for "witch" in Congolese languages, such as ndoki or mchawi, are applied to persons of either gender. Some anthropologists have responded translationally by using the word "wizard" anytime a male is in view, and "witch" any time a female is in view. But for us to follow this pattern would misleadingly imply there are two different indigenous categories, differentiated by gender. For most Congolese languages this is not the case. It is possible for either a man or a woman to be a ndoki. Thus this report follows a widespread anthropological convention of using the single term "witch" for both males and females. Our references to "child-witches" relate to boys and girls.

An additional complication relates to an old anthropological distinction. Some English-speaking anthropologists, following the lead of Edward EvansPritchard (1937), have suggested using two words in English to differentiate two possible categories of person thought to be the evil cause of harm in the lives of others. They suggested reserving the English term "witch" for the reputedly evil person (male or female) said to harm others through inborn psychic power, and the term "sorcerer" or "sorceress" for the reputedly evil person believed to harm others through a magical manipulation of objects and words using learned magical techniques. This distinction in English is an awkward one. The English suffix "-craft," added to "witch," makes "witch" an odd word to reserve for the person that has no "craft," only psychic power. And in English usage, "sorcerer," rather than being reserved purely for the person whose core identity involves causing harm magically, has sometimes confusingly been used, even by prominent anthropologists (e.g., Levi Strauss 1963), for the professional shaman who offers his services to help heal clients. ${ }^{19}$ Other leading anthropologists have critiqued the witch vs. sorcerer

\begin{tabular}{lll} 
Lugbara & odjou & oleu \\
Ngbaka & wi de so & wi doa, wi tunumo \\
Ngombe & nganga & mwemba \\
Sakata & muu-ni-ngee & ngee, ilue \\
Swahili & mfumu, mganga & mulozi, mchawi, muchawi \\
Teke & mfumu, nghaa & moloo, nga mfura \\
Tetela & wetshi & doka \\
Tshiluba & muena mbuku, muena manga & muloji \\
Tshokwe & mbuki, mukwatshisa, mukwayithumbo & mukwawanga \\
\hline
\end{tabular}

\footnotetext{
${ }^{19}$ Because some anthropologists confusingly apply the term sorcerer to what others would simply call shamans (public magico-religious professionals that assist clients with their needs), such anthropologists will sometimes add the modifier "assault"-as in "assault sorcerer" or "assault sorcery" (Whitehead and Wright 2004; Wright 2015) to differentiate the identity of malicious persons thought to mysteriously and secretly cause harm to others.
} 
typology as unhelpful (e.g., Turner 1964, Shweder 2003). This distinction is present within relatively few cultures and languages. Thus, this anthropological discussion occurs primarily in English-language writings, not French. ${ }^{20}$ Initial anthropological hypotheses about the supposed consequences of a culture affirming one ideology of occult power vs. another, were contestable (Turner 1964). And this typology failed to exhaust the possibilities. That is, it is possible to accuse another person of causing harm 1) through inborn psychic power, 2) through learned use of magic (not involving spirits), but also 3) through forms of empowerment by sentient spirits. And indeed, under the impact of Christianity, ideologies of purely psychic human powers, or impersonal power manipulated magically, increasingly give way to, or are incorporated into, new hybridities involving ideologies of demonic power-what Onyinah (2004) aptly refers to as "witchdemonologies." The underlying psycho-cultural pattern of witch-accusations continues, whereby misfortunes are attributed to malignant neighbors, relatives, or colleagues, but formal ideologies about the precise nature of their supposed secret powers are often ambiguous and change over time. In short, this older distinction between witches vs. sorcerers is only occasionally maintained in current anthropological writings because this distinction seldom seems relevant to observed patterns of vocabulary usage in the contemporary world. And this would seem particularly true in Kinshasa today.

In this report, while we will refer to various ideas about how witches exercise power, we will not make any specific concept of power foundational to our definition of "witch." Rather, any time one human being, male or female, is accused of being the malignant cause of harm to another based on some sort of occult power, and then identified as ndoki, ntshor, mchawi, muloji, oleu, or sorcier, we will translate this as "witch." And whatever actions or power they are said to exercise in accomplishing such harm, we will refer to as "witchcraft." We will not apply these words ("witch," "witchcraft," "bewitch") analytically to the normal identities and specified roles and activities of traditional healers, shamans, and diviners. Our usage is consistent with current anthropological practice, as well as with Congolese traditional linguistic distinctions.

A final complication is that under the influence of Christianity, many Congolese Christians today insist that these traditional Congolese linguistic distinctions mislead. Traditional diviners and healers only pretend to help others, while in fact working to cause harm. They are thus, the argument sometimes goes, actually witches (Wallo Mutsenga 2013). Later in this article, we will consider ways in which Christianity has been used to reconfigure older understandings of witchcraft. But even under such revised usage, the core charge when labeling someone a witch is that they cause harm to others.

When someone is accused of being one of these "witch" identities (ndoki, ndoshi, oleu, ngee, ntshor, mwemba, muloki, muloj, bulozi, murogi, akut, maye, umthakathi, mchawi, mfiti), the core offense of which they are accused is that they have caused, through evil occult power, someone else's misfortune, poverty, infertility, sickness, or death. An orphan accused of having caused his parents' death, to be clear, is accused of being a murderer. Thus, the central accusation whenever a witch label is applied to some person is that this person is the cause of misfortune, morbidity, or mortality in the lives of others. They are understood as destroyers of life and human flourishing. Such labels are consequential. Those labeled in this way are feared and often hated.

\subsection{The Critical Role of Pastors and Churches}

As Kinshasa residents struggle to make sense of the vicissitudes they experience, it is frequently to the teaching and preaching of church leaders that they turn. And Kinshasa pastors often encourage their listeners to interpret their misfortunes as caused by neighbors or family members that are secretly witches. Not infrequently church leaders remind their listeners that even the children living in their own homes might be witches that are to blame for family tragedies. ${ }^{21}$

Furthermore, other than schools, churches in Kinshasa probably work with more children than any other social institution. Not only are many children regularly brought to church with their families, but families also bring their children to church "intercessors," "prophets," and pastors for spiritual counsel and prayer, especially when suspicions of witchcraft are involved. In the past, people approached traditional diviners and healers (with identities listed in footnote 15 above) for help in identifying whether someone was a witch, and for help in counteracting witchcraft. Today many people prefer to approach church leaders for this same help. And many church

\footnotetext{
${ }^{20}$ The French word sorcier, despite its apparent similarity to the English word sorcerer, does not correspond to the narrower meaning of "sorcerer" used by English-speaking anthropologists.

${ }^{21}$ Evidence for this comes from our survey results to be explored later in this paper, but also in pastoral writings on the subject. For samples of the writings of local Kinshasa pastors that do this, see Wallo Mutsenga 2013; Kigalu Mangala 2008, 2013; or Kalonji Mbuyi 2003, 2007, 2010, 2014.
} 
leaders do claim the ability to know who is a witch and how to fix the problem. Indeed, churches today, for good or ill, arguably more than any other social institution, play a central role in influencing people's understandings and ideas about child-witches, and their responses to children perceived to be witches. ${ }^{22}$

\section{Child Witch Deliverance}

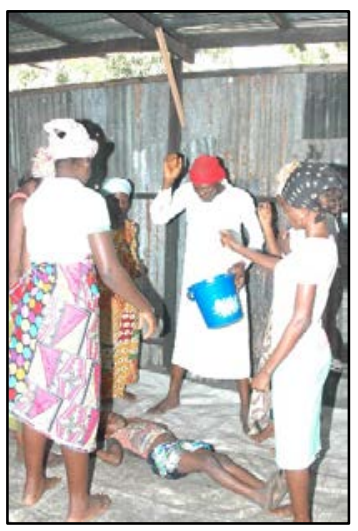

May 2017, Kinshasa. Photo by EPED.

While many scholars and human rights activists have stressed the negative effects of church involvement with witch accusations and treatment, others have suggested that churches are uniquely positioned to make a difference for good, when actively and rightly engaged on behalf of child protection and care. ${ }^{23}$ The following first-hand account ${ }^{24}$ by a Kinshasa pastor, Josué Mabélé, illustrates such an alternative pastoral role:

\section{Pastor Josué Mabélé's Story}

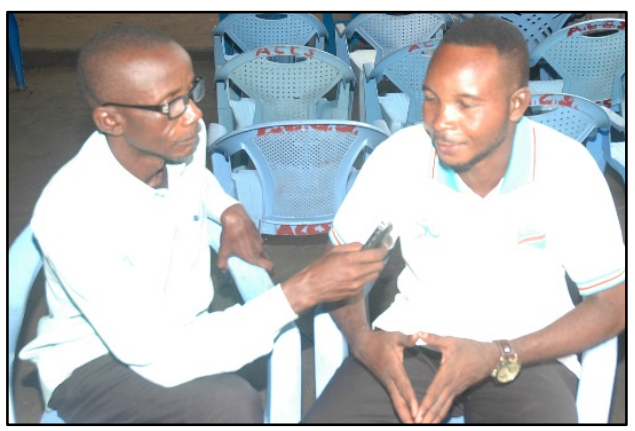

Pastor Josué Mabélé tells his account to Mr. Jean Alengo Jean of EPED

Christophe and Christian were cousins, 15 and 12 years old, whose families sent them to Kinshasa to further their education. ${ }^{25}$ Their host father was the biological father of Christophe and the uncle of Christian. Initially, he was pleased to receive them, and for a while, all went well. But this man's current wife was step-mother to these boys. The couple could not have kids, but the wife came into the marriage with a daughter from a prior relationship. Shortly after the boys came to live with them, the father began to experience economic hardships.

The stepmother then accused the boys of causing their problems through witchcraft. ${ }^{26}$ The two boys denied they were witches, but the mother influenced her husband (to suspect them of witchcraft). They mistreated them, deprived them of food, and moved their mattresses and clothes outside the house, forcing them to leave. The boys took refuge in an empty unfinished house.

One of my church members found out about their situation and took in the boys. He fed and cared for them. But then he approached me, explained the

\footnotetext{
${ }_{22}^{22}$ Ballet, Lallau and Dumbi 2019; Cimpric 2010; De Boeck 2004, 2005, 2006, 2009; De Boeck and Honwa 2005; De Boeck and Plissart 2003, 2004; La Fontaine 2009; Molina 2005; Pereira 2011; Riedel 2012; Snow 2017; Stobart 2006, 2009; Tate and Stauss 2006; Tonda 2008. According to at least some observers, the child-witch phenomenon is more prevalent in majority Christian communities than in Muslim ones. See Cimpric 2010, 15. Dr. Samuel Kunhiyop, the Nigerian leader of one of Africa's largest evangelical denomination's (ECWA), suggested (personal conversation, March 5, 2016, Nairobi) that in Nigeria those attending Christian churches are more likely to be accused of witchcraft by fellow-Christians than those attending a Muslim mosque are to be accused by fellow Muslims. If true, this is a pattern that needs to be better understood. More research comparing Christian and Muslim populations might be helpful to our understandings of relevant dynamics.
}

${ }^{23}$ See, for example, Aguilar Molina 2005; Pearson 2009; Pull 2009.

${ }^{24}$ Recorded May 6, 2017 in Kinshasa.

${ }^{25}$ From Mbandaka (in the province of Équateur) to live in Kinshasa (Mombele Square in Limete).

${ }^{26}$ She had earlier accused Christophe's older brother of witchcraft, leading to his ejection from the home, and had reportedly heard rumors that Christian had been accused of witchcraft by others. So here she accused both together. 
situation, and clarified that he was not able to afford to care adequately for them. He asked if I would take them into my home and care for them. I agreed and welcomed them into my home.

When we first took them into our home, they were very skinny. Their health was bad. People were saying, "See, witches usually have poor health." But when we took them in, and brought them into our church, and cared for them, they started to change right away. Before long, they were in good health and were developing normally.

Our goal was to reinsert them in their families. By the grace of God and his blessing, both boys have been reinserted in their families with peace restored and where they are comfortable. We keep in touch with them. Christophe is back with his biological father, and Christian is with his biological mother. They are attending school. Both are very smart kids, " $A$ " students, valedictorians. As we speak, Christophe is taking his SAT, and his younger brother is in $8^{\text {h }}$ grade. They are doing well.

Pastors exercise significant cognitive and moral authority in Kinshasa. And, as we shall see, how they exercise such authority in the context of child witch suspicions has significant potential either for good or ill.

\subsection{The Vision and Mission of EPED: The Organization Carrying Out This Research}

This research was carried out by the staff of EPED, l'Équipe Pastorale auprès des Enfants en Détresse, under the supervision of Révérend Abel Ngolo (Secrétaire général-représentant légal of EPED) in partnership with Robert J. Priest and Timothy Stabell, and with financial support from Trinity Evangelical Divinity School's "Henry Center" and from "Stop Child Witch Accusations." EPED is a national nongovernmental and non-profit organization based in Kinshasa, whose mission is to contribute to the protection, welfare, and safety of children with a view to preventing all forms of ill-treatment and abuse within families and in society at large. Its vision is for a Congolese society in which every child is loved, healthy, educated, safe, and free to realize all the potentialities that God has given them.

But while this vision and mission are largely shared by other sister organizations that focus on child welfare in Kinshasa (such as REEJER and CATSR), ${ }^{27}$ EPED is an explicitly faith-based organization that works closely with a network of pastors. Its staff is composed of pastors, as well as of nurses, social workers, and educators. And it retains a central focus on the role of pastors and churches in problems related to child-witch accusations, but also on pastors and churches as key to the promotion of healthy understandings and practices related to children, both in families and the church. That is, it aspires to bring change by impacting churches and church leaders.

EPED Worker Assisting Child

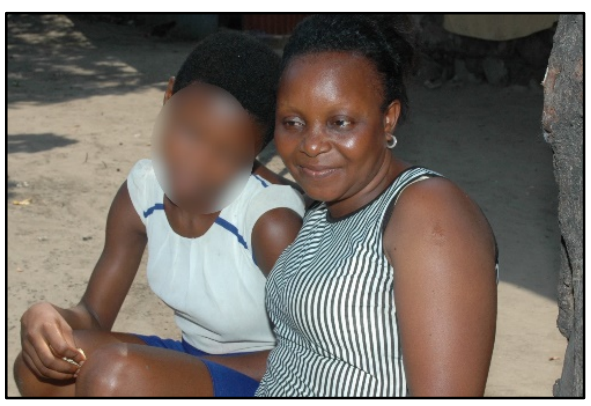

14-year-old Exaucée ${ }^{28}$, after eviction from her home as a witch, receives help from Mrs. Liliane Suaku, EPED social worker, with the goal of family reintegration.

In the following first-hand account, ${ }^{20}$ a pastor whose prior ministry was focused centrally on eliciting childwitch confessions describes how EPED influenced him, leading to a fundamental shift in his approach to children accused of being witches. That is, this extended case illustrates some of the church dynamics in Kinshasa that human rights activists have rightfully been alarmed over. But where secular human rights organizations have had limited success in persuading pastors to change their views, this account illustrates how the faith-based model of engagement carried out by EPED can bring deep transformations within the thinking and practice of Christian pastoral leaders.

\footnotetext{
${ }^{27}$ Réseau des Educateurs et Jeunes de la Rue (REEJER) and Comité d’Appui au Travail Social de Rue (CATSR).

${ }^{28}$ This name is a pseudonym.

${ }^{29}$ Recorded May 11, 2017 in Kinshasa.
} 


\section{Pastor Jean's Story}

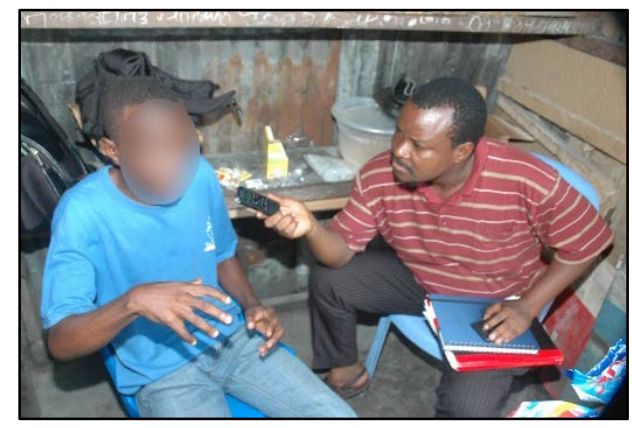

Pastor Jean ${ }^{30}$ tells his story to Pastor Faustin Tshiebue, Deputy Executive Director of EPED

My name is Pastor Jean. Since 2001, I have pastored a church in the municipality of Njili. But, before I tell you about my ministry-the ministry that EPED helped me understand was wrong-I will share my birth story since it influenced me.

My dad was married to my aunt, with whom he had a son. When my aunt was in the hospital, her sister (who was my mother) came from the village to help out. She was twelve years old. My dad got her pregnant. This created conflicts in the family and they tried to abort the baby. But it did not work out. Three months after I was born, they sent my mom back to her village. I learned I was illegitimate when I was six years old. I suffered under the weight of it, never knowing a mother's love. I was blamed for everything negative that happened. For example, I was blamed as a thief every time something would disappear in the house. They would buy clothes for my siblings, but not for me. So I became a professional thief. There were no secret hiding places from me. I knew about all the hiding places they used. It got to where I started stealing shoes in the neighborhood and selling them in the market. When the neighbors complained, my dad humiliated me by making me kneel in front of everyone, and my brothers nicknamed me "Jaskram." My dad took a knife, put it in the fire, and sliced my back. I cried and screamed. They took me to the hospital. There was a scandal, to the point where they arrested my dad and took him to court, asking me if they should incarcerate him. I said, "No, just let him go."

I have a scar right here, from the knuckles he hit me with when I was eight. The scar is still here. I have another scar here, from his whip. They were unbelievably insane whippings. Later I rebelled, and said to my dad, "Am I the one who slept with my mom, that I should deserve such suffering? Today, I am bearing your burden. I have scars all over me, on my legs, my head-you burnt my back, look at all these scars. I prefer today to live outside this house rather than living within the family. I left my parents' house when I was 14.

Much later, when I became a pastor, this childhood still had an impact on me. Even when I would receive children, I did not love them. Since I was working in the prefecture of Njili, many children were brought to me. I would look in their eyes, and if their eyes were light brown, I would say they were witches. When I saw kids with ringworm and scabs on their heads, I considered them witches. If a child had a strong smell, the same conclusion. If a child during prayer time was making gestures with their hands, that was another sign they were a witch. They would move their fingers as if on a phone call to another world. "Cabalistic pandemonium," I would tell the person assisting me, "you see, he's giving a call, he's a witch."

All of these things made me one of the most famous pastors. People started to consider my church as the church to discover child witches. They would bring children in large numbers, and I would pray for them until they were delivered. That became my small market, helping the parents of the children. Parents were bringing me money because every deliverance requires a special offering. Every work generates abundance. I had a job and it required remuneration. Pay was needed for the work to go forward. /This was alsol getting me into an acceptable social standing, financially speaking. What hurt me the most was seeing how many kids were left out in the street, because some would not confess.

But others were confessing-since I forced them to. Sometimes I would press on their eyes to force them to admit. Sometimes I would have them drink vegetable oil. I would have them fast lup tol seven days. If you don't admit before that time ends, I would force you to tell me, "what was 'your ride' Ito the other world]?" And the child would say, "I fly with this stick." Others would bring me their fufu spoon... I would burn these tools in daylight. It was making me famous. Others would tell me, "See this cut [on my body]. It's like my pocket. When I go out at night, I fill it with meat." I would tell their mother, "See, I just uncovered him." Others I would put through the process of deliverance, and after the third day, I would make them drink vegetable oil. Of course, if you fast and then drink vegetable oil, you will throw up. When they threw up, I would say, "See, he just threw up what we were looking for."

Sometimes I locked children in the church. I would tie them, and even chain them, to a pole.

\footnotetext{
${ }^{30}$ This name is a pseudonym.

Priest, Ngolo, and Stabell, Christian Pastors and Alleged Child Witches
} 
Others I would tie their feet so they would not leave. I wouldn't let them sleep at night, because if they can't sleep, then they can't go to work lin the witch world]. I told myself they were living every day to go to work around midnight to come back at $4 \mathrm{AM}$, so if I didn't let them sleep, they would be absent at work, until they were fired. That's the way it was. We had high benches without back support. If we were praying, I would have them sit on the bench. If they dozed off, they would fall. I would put them back on the bench, which was quite high. I put them on the bench so they wouldn't sleep. I wouldn't let them doze off. If they dozed off, that meant they had left. So if I kept them awake for 2 or 3 days, these absences would cause them to be fired and lose their [witch] jobs. That's the way I was doing it. It was a form of torture-physical and moral torture.

If a child did not admit [to being a witch], I would tell the parents to kick him out because he would be a danger to his family. "He will set you back." Even in the church, I was kicking them out. If you refuse to open your heart to me, I would kick you out of the church. If you refused deliverance, I would kick you out. Through these practices, a lot of children were kicked out. They were many. Others were beaten. I would beat them. Nobody had mercy on me /when I was a child]. I was born and grew up suffering. So that's why I beat them uncontrollably.

Something even worse happened when I married my wife. Six months after we were married, her seven-year-old son came to live with us. One day I told my wife, "this child is working with darkness." She started crying. We had a fight. Since lthe problem] was in my own house, it was something I couldn't address, so I took him to another pastor. That pastor told me, "this child is a high-level Ndika witch at a point of no return. He will never leave his witchcraft." These high levels, Ndika or Koba, were categories that I told parents to separate from. Because they could kill you, destroy your jobs, destroy your family, disintegrate the household. It's better to get rid of them. Leave them in the street because it's better to get rid of a rotten tomato than to have more rotten tomatoes because of /contamination from] the first one. That was my principle.

When that pastor informed me of the level of witchcraft of my adoptive son, which he wouldn't agree to let go of, I told my adoptive son, "you have two choices, abandon witchcraft, or else!" I started torturing the child. I tortured him, tortured him, and kicked him out. I said, "Let him return to the family of my wife's parents where he came from." When he returned, since that label was accompanying him, my family-in-law concluded that if the pastor who is considered the "doctor of deliverance" of child witches got rid of his child, that child must be of a very high level of witchcraft. "So how can we, that are not doctors, take care of him, and deliver him." They also kicked him out. He started to live at Saint Therese, collecting charcoal. He would pick it up and sell it. And my wife would be weeping at night thinking about her child being left out like that-until she went herself to bring her child back. But this coliving did not work out. This time, he ran away. When he ran away, he ended up in an orphanage in Bamdale County. From Bamdale, they would come to me to reason with me: "You are a pastor, you are a man of God . . " My heart was softened, but I still couldn't accept the idea of living with a child witch.

But glory to God, one day, I met Pastor Faustin. We started hanging out, and one day, he gave me a set of questions that hit me like a hammer because it regarded child witches. When he told me to answer in a written way, I answered. But I did not answer sincerely because it was something like piercing me with a spear. When I answered, I gave it back to them and thought, "Get out of my face with those things." But then Pastor Faustin invited me, "We have a conference of EPED concerning child witches that would interest you." He and his wife did this in a way that insisted I come. I went unwillingly. When I went, I heard the teachings and training. I was so moved that I cried. I cried very much, and said, "My God!"

When I went back home, I apologized to my wife. We had to find that child that became a child of the streets. We looked for him and brought him home. I asked my wife for forgiveness. Today my wife and I are living in a good way. We are living in peace with our child. I am supporting him. I do not think evil about him anymore. I do not have nightmares about him anymore. This is due to the influence of EPED and their teachings on me. I let go of the practices I was doing in the church. I praise God that today I am free.

My sharing openly with you is like paying back a debt of the wrongs I did. May God bless EPED by giving them means, financial means, because this is not easy work. Those children are complicated. To take a child off the street, to put him back into a family setting, to have him back in church, to put him back into a social setting requires a lot of means and effort. EPED has helped many children.

It helped my own family. My family is living in peace because of EPED. EPED has been a huge blessing. I am being honest. Knowing that God forgave me since it was out of ignorance that I was doing these things, I feel free before God. I have gotten to the place where I love kids. I am a protector of kids. Today if you want to hurt a child, I defend the child, even if the child is being labeled a childwitch. I am not pleased by it anymore, because it was 
something I did from anger, because of the way I was born. Today, if God blesses me, I want to be among the host families receiving abandoned and rejected kids. I want to support them and share their suffering and the suffering of their parents.

The above account illustrates both challenges that EPED is confronting and some of the hoped-for outcomes of its work. Thus, EPED was well-positioned and motivated to partner on this research, hoping to benefit from the research findings as it goes through its own internal review and planning process.

\subsection{Aims and Goals of This Study}

This research examines the ways in which Kinshasa pastors are engaging the child witch phenomenon. It is expected that research results will be of interest to scholars (such as anthropologists, world Christianity scholars, or theologians) and to a wide variety of more applied stakeholders (human rights activists, church leaders, NGOs) interested in the welfare of these children. And because African church leaders play trusted roles in helping others understand and engage witch allegations, we hope above all that this research provides a helpful foundation for engaging the community of African theological and pastoral leaders in a conversation about the impact of theological understandings, congregational discourses, spiritual disciplines, and pastoral practices on the well-being and flourishing of vulnerable children.

This research surveys pastors of Kinshasa on the subject of child witches, and addresses the following questions: What have pastors directly observed concerning child witch allegations? How many accused children have they had contact with, and of what age and gender? What is the profile of those most frequently identified as witches? How does this compare with witch accusations directed at adults? What harms are child witches accused of causing? What were the factors seen as evidence of guilt? What specific practices are carried out with such children in the context of church deliverance ministries? To what extent do church discourses (prayers and sermons) reference (and reinforce) the dangerous reality of child witches, and in what ways? What do pastors believe and teach about the alleged power and guilt of child witches said to have harmed others through witchcraft? To what extent do pastors benefit through a ministry of deliverance for child witches? To what extent do pastors and churches protect children from witch accusations? Are they aware of the Congolese law making it a crime to accuse a child of being a witch? With what implications? To what extent, and in what ways, do churches work to help children become reintegrated into the families that rejected them as witches? To what extent do churches provide medical care, educational support, or foster homes for such children? How do theological education and denominational or theological tradition impact the beliefs and practices of pastors and their churches as they relate to child witches?

\section{Chapter 2: Research Methodology}

\subsection{Research Design}

Prior research on child-witchcraft has been largely qualitative rather than quantitative. Such qualitative research has contributed to an understanding of beliefs, practices, experiences, and social processes related to child-witch accusations. But it is essential that quantitative research builds on the foundation of this prior qualitative research if we are more fully to explore the prevalence and distribution of the specific patterns identified in this prior research and to consider possible implications of the correlations observed.

Based on a review of prior publications, an initial questionnaire was designed by Robert Priest and fieldtested in Kinshasa with 52 pastors in August of 2014 at a conference co-sponsored by EPED and Stop Child Witch Accusations. The results were carefully analyzed, and the leadership team of Équipe Pastorale auprès des Enfants en Détresse (EPED), themselves social workers and pastors with years of first-hand experience working to care for Kinshasa's street children and under the leadership of Pastor Abel Ngolo, worked for several days together with Robert Priest and Timothy Stabell in revising the wording of survey questions and response options, and adding additional questions to the survey. The final 82-item survey addressed the research questions already described above under "Aims and Goals of the Study.”

\subsection{Research Population}

Our target population was the pastoral leaders of the many thousands of congregations in Kinshasa. ${ }^{31}$ This was intended to include anyone on the congregational staff with pastoral/ministerial roles, whether or not they

\footnotetext{
${ }^{31}$ While Revival church leaders informed Katrien Pype $(2012,36)$ of a 2005 census that identified 12,000 revival churches in Kinshasa, she was unable to actually "lay hands" on the census results. A more modest number is provided by Matangila $(2006,78)$, who counted over 3,000 revival churches in Kinshasa (cited in Pype 2012, 36). In any case, when adding in Catholic, Protestant, and African Independent churches, there are many thousands of congregations in Kinshasa.
} 
were fully ordained. Thus, many with the title or role of evangelist, prophet, or assistant pastor were included in our intended population, whether or not they were ordained. The survey was intended, however, to exclude staff with non-ministerial roles (such as secretaries), and to exclude categories of lay leaders (such as "intercessors") that in Kinshasa typically serve in non-remunerated roles.

These pastoral leaders operate mostly within four major and distinct church traditions.

2.2.1 Roman Catholicism has a long history in the DRC and operates 143 parishes in Kinshasa. While in its earlier history the Catholic Church in Kinshasa was not known for directly addressing witchcraft beliefs and realities, this has changed in recent decades. Under the impact of 1) the Catholic Charismatic renewal movement, 2) the adoption of new leader and non-leader roles influenced by those of the Revival Churches (such as the role of evangelist, intercessor, or even prophet), and 3) a focus on family ministries, local parishes of the Catholic Church in Kinshasa have come to be known for ministries that sometimes include a focus on the "deliverance" of so-called child witches.

2.2.2 Protestant missions and denominations also have a long history in Kinshasa, with 62 of these mission-initiated denominations legally incorporated under the umbrella of the Church of Christ in Congoin French, Église du Christ au Congo (ECC). In earlier years, these churches, perhaps under the influence of foreign missionaries, often took the position that witch suspicions or accusations were without merit. They were not known to have any regular practices related to engaging witchcraft suspicions or accusations. However, in recent decades these Protestant churches have been deeply influenced by the success of Revival Churches. That is, they have increasingly endorsed an understanding of the Holy Spirit as gifting church leaders with unusual powers and understandings. Many of these churches now also have the new recognized roles of prophets and intercessors-roles they learned from the Revival Churches. And it is now not uncommon for these churches to be involved in ministries focused on the deliverance of children alleged to be witches.

2.2.3 African Independent Churches began to emerge in the DRC, beginning in the $1920 \mathrm{~s}$ with Kimbanguism-formally "the Church of Christ on Earth by the prophet Simon Kimbangu.” As a Baptist, Simon Kimbangu reportedly performed miracles and claimed for himself special powers and knowledge from God. The older mission church establishment rejected him and called for his arrest, thus triggering the birth of a new breakaway movement-a movement grounded in a mix of Christianity and African traditional religion.
Kimbanguism is strongest in Bas-Kongo, but also has a significant presence in Kinshasa. Other African Independent Churches follow the leadership and divine instructions of Prophet Kimpa Vita or Prophet Ne Muanda Semi. These churches have regular practices involving the identification and deliverance of child witches, practices partly based on older African traditions.

2.2.4 The Revival Churches (Églises de Réveil) emerged in the 1970s largely out of the Protestant Churches, but also from Catholicism. Influences included the Catholic Charismatic Renewal Movement, the Assemblies of God (itself a Protestant [ECC] church), and other Protestant ministries focused on the Holy Spirit and the gifts of the Spirit. Unlike Protestant churches with denominational structures and identities, these churches are usually either independent congregations or small clusters of congregations associated with a single prominent leader. Some of the largest congregations in Kinshasa are from this tradition. Rather than stress Bible knowledge and formal theological education as the foundation of pastoral authority, these churches placed a high value on gifts of the Holy Spirit. They pioneered new ministry roles (intercessor, prophet, evangelist, apostle) each of which was believed to depend on the exercise of special spiritual power and knowledge. These churches focused their preaching on deliverance from sickness, poverty, and other misfortunes understood as related to demonic realities and to witchcraft. They pioneered approaches to the deliverance of child witches that sometimes subjected children to fasting, the ingestion of noxious substances, shaving of the head (under the idea that hair serves as an antenna of communication), burning, and so on.

While the Protestant Churches initially repudiated the Revival Churches, the unusual and highly visible success of Revival Churches has resulted in greater respect and influence, with Revival Church leaders increasingly likely to study in Protestant theological schools, and with Protestant Churches themselves increasingly adopting beliefs and practices of the Revival Churches. And, of course, a majority of Revival Church leaders have come out of Protestant backgrounds. Thus, the early marked divide between the Protestant and Revival Churches has significantly lessened.

\subsection{Sampling and Data Collection}

Our target population was pastoral leaders. But these pastors came from scores of denominations, small networks of churches, and independent congregations. Because we lacked any adequate sampling frame from which to draw a random sample, we 
employed a combination of purposive and stratified sampling.

Since population estimates were available for each of Kinshasa's 24 municipalities, this allowed us to carry out stratified sampling. A target of 1,000 respondents was set, and a demographically-weighted number of desired respondents from each municipality was determined. Under the supervision of Reverend Abel Ngolo, trained social workers and pastors were assigned different municipalities to carry out research, and given the target number of desired responses for each municipality. Researchers visited local churches street by street and invited pastors to fill out the survey. Follow up phone calls and visits were carried out to encourage survey completion and to collect the completed surveys. Pastors were contacted by phone, at church gatherings, and by personal visits to the church, and were asked to fill out the survey. Follow-up phone calls and visits were conducted to encourage survey completion and collection. Data collection was pursued over six months in 2015.

The following table provides the demographicallyweighted target for each municipality, the number of surveys collected in each municipality, and what percentage the completed surveys were of the planned total.

Table 2.3 Surveys Stratified by Municipality

\begin{tabular}{lccc}
\hline Municipality & $\begin{array}{c}\text { Demographically } \\
\text { Weighted Target }\end{array}$ & $\begin{array}{c}\text { Actual } \\
\text { Completed } \\
\text { Surveys }\end{array}$ & $\begin{array}{c}\text { Percent } \\
\text { of Initial } \\
\text { Target } \\
\text { Reached }\end{array}$ \\
\hline Bandalungwa & 37 & 18 & $49 \%$ \\
Barumbu & 24 & 15 & $63 \%$ \\
Bumbu & 42 & 44 & $105 \%$ \\
Gombe & 10 & 2 & $20 \%$ \\
Kalamu & 57 & 33 & $58 \%$ \\
Kasa-Vubu & 31 & 23 & $74 \%$ \\
Kimbanseke & 128 & 6 & $5 \%$ \\
Kinshasa & 27 & 10 & $37 \%$ \\
Kintambo & 18 & 14 & $78 \%$ \\
Kisenso & 44 & 27 & $61 \%$ \\
Lemba & 52 & 49 & $94 \%$ \\
Limete & 47 & 26 & $55 \%$ \\
Lingwala & 18 & 18 & $100 \%$ \\
Makala & 45 & 49 & $109 \%$ \\
Maluku & 18 & 1 & $6 \%$ \\
Masina & 62 & 25 & $40 \%$ \\
Matete & 35 & 25 & $71 \%$ \\
Mont Ngafula & 18 & 22 & $122 \%$ \\
N'DJili & 62 & 24 & $39 \%$ \\
N'Sele & 12 & 172 & $1433 \%$ \\
Ngaba & 25 & & $108 \%$ \\
& & &
\end{tabular}

\begin{tabular}{lrrr} 
Ngaliema & 106 & 13 & $12 \%$ \\
Ngiri-Ngiri & 33 & 27 & $82 \%$ \\
Selembao & 49 & 43 & $88 \%$ \\
\hline TOTAL & 1,000 & 713 & $71 \%$ \\
\hline
\end{tabular}

Overall, after several months of data collection, we achieved a sample size that was $71 \%$ of the original goal of 1,000. For 19 of the 24 municipalities, we achieved between $37 \%$ and $122 \%$ of the intended target number. We significantly oversampled in N'Sele and undersampled in Kimbanseke ${ }^{32}$ and Maluku (a distant rural municipality), but otherwise have sampled at reasonable rates for the other municipalities, given the research challenges faced.

Below we will discuss some of the unusual research challenges that made it difficult to get a fully satisfactory stratified sample. Two factors can be mentioned here. Different municipalities historically have had differing levels of police intervention related to church practices involving children alleged to be witches. And this seems to have impacted the comparative level of suspicion or openness encountered by researchers in each municipality. N'Sele, for example, is rather distant from the places where police interventions have been strong. And the known and respected local medical and educational ministries of EPED in N'Sele helped establish trust. This doubtless contributed to the unusually high numbers of respondents in N'Sele. Second, since each municipality had its own researcher or research team that varied in their relational ties and knowledge of their assigned municipality, and perhaps in their skills, training, and motivation, it should not surprise that research teams varied in the extent to which they achieved targeted goals.

In terms of church traditions, we had no precise numbers on how many Catholic, Protestant, African Independent, or Revival Church pastors exist in Kinshasa, although all four are present in high numbers. That is, we had no way to estimate the actual population of pastoral leaders in each community in order to establish weighted targets, as we did with municipalities. Thus, we simply worked hard to survey significant numbers of pastoral leaders in each of the four main traditions.

However, field researchers reported major differences between the willingness of pastoral leaders from the different traditions to respond to the survey. ${ }^{33}$ Revival church pastors, coming largely from independent churches and from traditions that value

\footnotetext{
${ }^{32}$ Kimbanseke, the Kinshasa municipality with the largest population, a municipality filled with churches, is our most serious case of undersampling. In this instance, during the months of data collection, reports from Kimbanseke's lead researcher had all been positive, suggesting that a significant number of surveys were being collected. But when final surveys were due, this researcher failed to appear. Inquiries revealed this researcher had left the region over a "family emergency." All subsequent contact efforts failed, and by this time it was too late to start over.
}

${ }^{33}$ Unfortunately, records on how many were approached, and either declined or accepted, were not kept. 
publicity and confident openness to outsiders responded at high rates. According to one of EPED's lead researchers, " $99 \%$ of the time" when he approached a Revival pastor, the pastor would agree to fill out the survey. He estimated that $70 \%$ of the time Protestant pastors agreed to fill out the survey. But he then described sequentially approaching 30 Kimbanguist churches and being denied at each, before finally getting a single Kimbanguist pastoral respondent. That is, the African Independent Churches were reportedly more suspicious and reserved, operating almost like secret societies, and markedly different from the Revival Churches in their openness. Our sample of pastoral leaders from these churches is relatively small $(\mathrm{N}=62)$.

Finally, the method of directly approaching pastoral leaders at local churches, which worked well for Revival and Protestant pastors, did not work well with Catholic pastoral leaders. Local research assistants found it difficult to get past parish gate-keepers and actually gain an audience with the highest (ordained clergy) local church leaders. And, when they did get access to such leaders, these leaders often indicated they would need to check with superiors before they could fill out the survey. Thus, each completed survey by formal clergy often required multiple trips to gain initial access, as well as multiple follow-up efforts to collect the completed survey. By contrast, Catholic parishes often had family-oriented ministries and Charismatic Renewal ministries influenced, in part, by Revival Church patterns. And these ministries often had nonordained pastoral leaders with titles not commonly associated with Catholicism-such as the title of Prophet. It appears that these leaders were easier for local researchers to gain access to for purposes of the survey. Thus, our sample of Catholic congregational leaders was relatively small $(\mathrm{N}=52)$, with only $25 \%$ of surveys completed by formally ordained Priests, and the remainder completed by non-ordained pastoral leaders.

A couple of observations need to be made about our data for these four traditions. First, both because this was not a random sample and because of differing response rates, our data cannot be used to estimate the relative populations of pastoral leaders that exist in each tradition. Second, our data is clearly strongest for Protestant and Revival Churches, both because of the larger sample size for each, and because they responded at relatively high rates. But the results for Roman Catholic and African Independent Church leaders are nonetheless of interest, and so we include them in our analysis while cautioning readers to recognize the limits of the data with respect to these two categories.

\subsection{Data Entry and Analysis}

The data from completed surveys were entered into SPSS for statistical analysis. Results were discussed at length with EPED staff, to enhance understandings of the likely meaning of responses.

\subsection{Research Challenges}

In addition to research challenges and limitations that have already been mentioned, the survey took many pastors a long time to fill out, and this may have contributed to the failure of some to complete the survey, especially those with less education. Despite assurances of anonymity, and explanations of the purpose of the research, some pastors declined to participate out of fear that the survey was intended to collect information on behalf of the government to allow the government to police churches. To be clear, our survey was asking about behavior (accusing children of being witches) that violates Congolese law. It is thus possible that pastors with the most to lose, that is those most active in child witch accusations might have declined to complete and submit the survey at higher rates than others. And the fact that this article's lead author (Robert Priest) did not speak French meant that every step of the process required extensive processes of conversation and translation-with a great deal of attention to the meaning of words. Rev. Ngolo and Dr. Stabell, by contrast, were fluent in French and through their own experience and research deeply knowledgeable about Congolese contextual realities related to our topic.

\subsection{Supplemental Qualitative Research}

Finally, as we commenced analysis, it became increasingly clear that supplemental qualitative research was needed to better understand the meaning of some of our quantitative survey results. Prior qualitative research by other scholars did not provide answers to some of our questions. Thus Robert Priest spent May of 2017 in Kinshasa and partnered with EPED pastoral staff in carrying out three additional qualitative research steps intended to enhance understandings of local meanings.

a) Our team interviewed several individuals that had been accused of being child-witches, and several others who had played pastoral roles in addressing child-witch accusations, about the nature of their experiences. These were recorded, with permission to use their stories, and with several of these accounts transcribed and translated into English ${ }^{34}$-including the above accounts by Sylvain Mbaki, Pastor Jean, and Pastor

\footnotetext{
${ }^{34}$ By assistants fluent in English, French, and Lingala. 
Josué Mabélé. In this report, we use the actual names of adult interviewees, with their permission, with the single exception of Pastor Jean, whose name is a pseudonym. Robert Priest discussed the content of each case with EPED staff.

b) EPED staff photographed some of their own research activities, including interviews conducted, and were granted permission to attend and photograph local church events involving deliverance of children thought to be witches. Photographs in this report have been selected and/or edited to conceal actual identities, with the exception of photographs of EPED leaders and pastors that explicitly agreed for their pictures to be included.

c) Third, EPED staff visited a variety of Christian bookshops and solicited input from others in finding manuscripts (published and unpublished) written by Kinshasa pastors on the topic of witchcraft. Several were identified as particularly influential, ${ }^{35}$ meriting careful content analysis, such as a pamphlet by Revival Church Pastor Malochie Wallo Mutsenga-pastor of one of the largest and most visible megachurches in Kinshasa. These were translated, in whole or in part, into English to facilitate analysis. ${ }^{36}$ Robert Priest and EPED staff discussed these writings together, and their meaning and significance.

d) Fourth, EPED staff visited Bible societies and Christian bookshops and purchased Bible translations in 15 Congolese languages spoken by Kinshasa residents. Arrangements were made for one or two older fluent speakers of each language (between the ages of fifty and eighty), speakers who had grown up in villages where this language was the mother tongue, to spend three or four hours one-on-one with Robert Priest and a professional interpreter. We focused on the vocabulary of witchcraft, divination, fetishism, and traditional healing. We explored the extent to which different identities were understood as gender-specific or not. We probed early memories of witch accusation episodes. We inquired how often, if ever, children were accused of witchcraft back in the rural or village settings they grew up in decades earlier. Finally, we examined Bible translations into each language, exploring whether and how indigenous words and concepts about witchcraft were featured in the translated Bibles in a variety of specific texts.

\section{Chapter 3: Presentation and Discussion of Findings}

\subsection{Profile of Pastors Surveyed and of Their Churches}

\subsubsection{Pastor' Sex, Age, Marital Status, and Number of Children}

A majority of respondents were male (83\%). Just over two-thirds were married $(68 \%)$, with male respondents more likely to be married $(72 \%)$ than female respondents (47\%). Age was highly correlated with marriage, with only $39 \%$ of those under 35 years old married, compared to a $91 \%$ marriage rate for those over 45. If we exclude Catholic respondents, the marriage rate for those over 45 rises to $95 \%$. Of respondents that were married, half reported having four or more children (for a mean of 4.4). The following table summarizes demographic information on age, sex, marital status, and number of children for respondents.

Table 3.1.1 Respondents by Age, Sex, Marital Status, and Number of Children

\begin{tabular}{llcc}
\hline & & Frequency & Percent \\
\hline Age & $18-24$ & 87 & $12.2 \%$ \\
& $25-34$ & 192 & $26.9 \%$ \\
& $35-44$ & 200 & $28.1 \%$ \\
& $45-54$ & 151 & $21.2 \%$ \\
& $55-64$ & 68 & $9.5 \%$ \\
& $65+$ & 15 & $2.1 \%$ \\
\hline Sex & Male & 590 & $82.7 \%$ \\
& Female & 123 & $17.3 \%$ \\
\hline Marital Status & Married & 484 & $67.9 \%$ \\
& Single & 209 & $29.3 \%$ \\
& Other & 20 & $2.8 \%$ \\
\hline \multirow{2}{*}{ Chimber of } & None & 138 & $19.4 \%$ \\
& $1-2$ & 192 & $26.9 \%$ \\
& $3-5$ & 218 & $30.6 \%$ \\
& $6+$ & 165 & $23.1 \%$ \\
\hline
\end{tabular}

\subsubsection{Ethnicity of Respondents}

There are more than two hundred ethnolinguistic groups in the Democratic Republic of the Congo. But in Kinshasa, most churches worship in French and Lingala. The primary exception seems to be the African Independent Churches that are often smaller, familybased, and ethnically homogeneous. These represent the primary settings in Kinshasa where one finds worship services in a variety of specific Congolese languages.

While most residents of Kinshasa carry out their

${ }^{35}$ Balibuno Zahinda Byamungu 2013; Kalonji Mbuyi 2003, 2007, 2010, 2014; Kigalu Mangala 2008, 2013; Wallo Mutsenga 2013.

\footnotetext{
${ }^{36}$ Each manuscript was scanned, converted to text (using Adobe Acrobat Pro), translated into English (using Systran -- a computer translation program), and with the translation double-checked and modified by assistants fluent in English and French. They were subsequently entered into the qualitative data analysis program NVivo for further analysis of themes and patterns.
} 
affairs using a combination of French and Lingala, Kinshasa residents nonetheless often identify with a specific tribal or ethnic heritage and retain close links to family and relatives back in their communities of origin as well as in Kinshasa. They exemplify varying levels of linguistic fluency in the relevant ancestral language and in knowledge of the witchcraft vocabulary and associated meanings and practices of their ancestral communities. The following table lists the most common tribal or ethnic identities claimed by survey respondents.

Table 3.1.2 Ethnicity/Tribe

\begin{tabular}{lcc}
\hline & Frequency & Percent \\
\hline Bangala & 12 & $1.7 \%$ \\
Kele & 7 & $1.0 \%$ \\
Kongo & 105 & $14.7 \%$ \\
Luba & 98 & $13.7 \%$ \\
Mbala & 30 & $4.2 \%$ \\
Mbundia & 25 & $3.6 \%$ \\
Mongo & 19 & $2.7 \%$ \\
Ngombe & 11 & $1.5 \%$ \\
Nyanga & 17 & $2.4 \%$ \\
Pende & 11 & $1.5 \%$ \\
Sakata & 24 & $3.4 \%$ \\
Sengele & 9 & $1.3 \%$ \\
Songe & 15 & $2.1 \%$ \\
Suku & 13 & $1.8 \%$ \\
Teke & 16 & $2.2 \%$ \\
Tetela & 18 & $2.5 \%$ \\
Yaka & 25 & $3.5 \%$ \\
Yansi & 33 & $4.6 \%$ \\
Yombe & 23 & $3.2 \%$ \\
Other & 123 & $17.3 \%$ \\
Undeclared & 78 & $10.9 \%$ \\
\hline
\end{tabular}

\subsubsection{Education of Respondents}

A majority of respondents (89\%) reported having completed secondary school (grades 7-12), with $62 \%$ reporting completion of a subsequent post-secondary degree. However, many reported education that was not formally theological. Nearly a third (29\%) reported that they had not taken any formal theological studies, with a third (33\%) having completed a four-year bachelor's degree in theology or above. The following provides the results.

Table 3.1.3 Education of Respondents

\begin{tabular}{ccc}
\hline Highest Level Completed & Frequency & Percent \\
\hline Primary (Grades 1-6) & 14 & $2.0 \%$ \\
Technical School & 62 & $8.7 \%$ \\
Secondary School (7-12) & 196 & $27.5 \%$ \\
Post-Secondary Level 1 & 307 & $43.1 \%$ \\
$\quad$ (3 yrs) - Niveau Graduat & & \\
Post-Secondary Level 2 & 129 & $18.1 \%$ \\
$\quad$ (2 yrs) Niveau License & & \\
Doctoral Studies or & 5 & $0.7 \%$ \\
$\quad$ Doctoral Degree & & \\
\hline Nature of Pastoral Training & Frequency & Percent \\
\hline Only Informal Training & 208 & $29.2 \%$ \\
$\quad$ While in Ministry & & \\
Bible Institute (2-3 years) & 236 & $33.1 \%$ \\
Theological Institute & 33 & $4.6 \%$ \\
$\quad$ (4 years with a diploma) & &
\end{tabular}

\begin{tabular}{lrr} 
Bachelors in Theology & 148 & $20.8 \%$ \\
Licence en théologie & 80 & $11.2 \%$ \\
Troisième cycle en théologie & 8 & $1.1 \%$ \\
\hline
\end{tabular}

Protestant respondents were higher overall on the educational level completed. But the most dramatic difference between traditions was not so much educational level, as the nature of formal pastoral training. Over $42 \%$ of Revival respondents indicated that they received their pastoral training only informally in the context of ministry, compared to only $15 \%$ reporting this for Protestant respondents, and $8 \%$ for Catholic ones. Protestant pastors were more likely to have completed formal theological programs beyond the Bible Institute level (58\%) than were Revival church pastors (19\%).

\subsubsection{Church Tradition of Respondents}

The following provides the breakdown of respondents in terms of church tradition, with the largest denominations or church associations listed under each, where relevant.

Table 3.1.4 Respondents by Church Tradition (and Denomination)

\begin{tabular}{|c|c|c|}
\hline Protestant & & 233 \\
\hline Communauté Baptiste & 58 & \\
\hline Communauté des Assemblée de Dieu & 40 & \\
\hline Communauté Evangélique au Congo & 12 & \\
\hline Communauté Presbytérienne & 10 & \\
\hline $\begin{array}{l}\text { Communauté des Eglises des Frères } \\
\text { Mennonites au Congo }\end{array}$ & 4 & \\
\hline Armée du Salut & 4 & \\
\hline Communauté Méthodiste & 3 & \\
\hline Revival & & 352 \\
\hline Assemblée Chrétienne de Kinshasa & 9 & \\
\hline $\begin{array}{l}\text { Centre Évangélique Gagner d'Ames } \\
\text { pour Christ }\end{array}$ & 7 & \\
\hline Nzambe Malamu & 6 & \\
\hline Cité Bethel & 5 & \\
\hline ERC & 5 & \\
\hline Pain de Vie & 3 & \\
\hline Roman Catholic & & 52 \\
\hline African Independent & & 62 \\
\hline $\begin{array}{l}\text { Église de Jésus-Christ sur la terre par son } \\
\text { Envoyé Spécial Simon Kimbangu }\end{array}$ & 8 & \\
\hline Église du Saint Esprit au Congo & 4 & \\
\hline Église Neo-Apostolique & 4 & \\
\hline BIMA & 3 & \\
\hline Église Prophétique & 3 & \\
\hline Mpeve ya Longo & 3 & \\
\hline Other/Not Sure & & 14 \\
\hline
\end{tabular}

While formal church identity was the principal way by which we identify the church tradition of respondents, in recognition of other influences that tend to cross-cut older church divides, we also asked respondents: "Does your church tend towards Pentecostal doctrine?" Three-quarters of respondents replied yes (74\%), ranging from a high of $88 \%$ for Revival church respondents to $73 \%$ of African Independent respondents, to $62 \%$ of Protestant 
respondents, and 38\% of Roman Catholic respondents.

\subsubsection{Size of Congregation Being Served}

Over a third of respondents (36\%) served in congregations with less than a hundred in weekly attendance. Another $39 \%$ served a congregation with more than 100 and less than 250 in weekly attendance, with a final $20 \%$ serving a congregation of more than 250 in weekly attendance.

Table 3.1.5 Size of Congregations Being Served

\begin{tabular}{ccc}
\hline $\begin{array}{l}\text { Average Sunday } \\
\text { Attendance }\end{array}$ & Frequency & Percent \\
\hline$<100$ & 256 & $35.9 \%$ \\
$102-250$ & 276 & $38.7 \%$ \\
$251-500$ & 102 & $14.3 \%$ \\
$501-1000$ & 43 & $6.0 \%$ \\
$1001+$ & 36 & $5.0 \%$ \\
\hline
\end{tabular}

Not surprisingly, given the Catholic parish structure limiting the number of Catholic congregations, Catholic respondents were more likely to serve in congregations with higher average levels of weekly attendance. Protestant respondents were less likely to serve in congregations of less than 100 (28\%) than were Revival church $(41 \%)$ or African Independent Church respondents (43\%). Otherwise, the size distributions were not notably different for the three non-Catholic traditions.

\subsubsection{Ministry Titles of Respondents}

Churches in Kinshasa have a wide variety of named roles and titles. Some of these roles (such as "intercessor") are considered lay and non-remunerated positions. Such positions are held by individuals that are not considered pastoral staff. Our intended focus was on those considered to serve in pastoral roles. This nonetheless covered a wide range including, on one end of the continuum, evangelists, prophets, and nonordained pastors, and on the other end, ordained pastors, including Doctors or Teachers of the Church, Apostles, Bishops, and Arch-Bishops.

While Catholic Churches historically had a range of religious leader titles reflecting status hierarchies (Priest, Monsignor, Bishop, Archbishop, Pope), the Protestant Churches that came to the DRC initially had a single religious category of Pastor. The leaders of Protestant denominations or church associations often had secular titles such as Moderator, General Secretary, or President. The African Independent Churches adopted elevated titles such as Prophet for their most esteemed leaders. And the Revival Churches stressed a variety of leader titles, such as Prophet, Pastor, Evangelist, Apostle, and Doctors or Teachers of the Church.

In recent years one can observe a great deal of borrowing between traditions. Thus, other churches borrow from Catholicism. For example, the leader of the ECC Protestant Church association currently is addressed by the title Monsignor, a practice that in an earlier era would have been anathematized in Protestant circles. Similarly, some Revival Church pastors wear clerical gowns and pectoral crosses similar to those used in Catholic Churches and occasionally employ titles such as Bishop or Archbishop. On the other hand, the success of Revival Churches has meant that other churches increasingly adopt their practices (related to such things as fasting, intercession, prayer, prophecy, music and other worship practices) and their church roles and titles (Prophet, Evangelist, Apostle) at local congregational levels. At local ministry levels, even the Catholic Church now has "Prophets." The following shows the leader titles that respondents reported using in their ministry.

Table 3.1.6 Ministry Titles of Respondents

\begin{tabular}{lcc}
\hline Ministry Titles & Frequency & Percent \\
\hline Evangelist & 136 & $19.1 \%$ \\
Prophet & 178 & $25.0 \%$ \\
Pastor (Non-ordained) & 174 & $24.4 \%$ \\
Reverend (Ordained) & 185 & $25.9 \%$ \\
Apostle & 24 & $3.4 \%$ \\
Bishop or Archbishop & 16 & $2.2 \%$ \\
\hline TOTAL & 713 & $100 \%$ \\
\hline
\end{tabular}

Fifty percent of respondents self-identified as Pastor or Reverend, $19 \%$ as Evangelist, $3.4 \%$ as Apostle, and a full $25 \%$ as Prophet. In most churches, Prophets and Evangelists are subordinate roles within a local church and under the direction of a senior pastor. Evangelists do outreach preaching in local markets, on buses, and organize evangelistic campaigns or one-on-one evangelism. Prophets give prophetic words to those who come to them and pray for them. Evangelists and prophets who demonstrate fruit in ministry may eventually move into more senior pastor roles in their church. Apostles also often serve under the sponsorship of some senior pastor that sends them out to plant a church elsewhere. That is, the Apostle title usually has the sense of being a missionary church planter, "in the tradition of the Apostle Paul."

Not surprisingly, our survey data shows that Prophets on average are younger $(60 \%$ are less than 35 years old), less likely to be married (51\%), more likely to be female (35.4\%), and with less formal education as compared with the other major categories. Evangelists are closest to Prophets on each of these, with ordained Pastors/Reverends having highest education, being older $(70 \%$ are over 45 years old), less likely to be female $(7 \%)$, and, for non-Catholics, more likely to be married $(93 \%)$. 


\subsection{Profile of Accused Children, According to Pastors}

\subsubsection{Why ask pastors?}

Because we could envision no easy way to systematically survey accused children or their parents and caretakers, we instead surveyed pastors about their experiences with and their knowledge of such children. When people suspect a child of having harmed someone through witchcraft, it is natural that they would share their suspicions with religious professionals whom they trust. To confirm that pastors are approached on these matters, we asked pastors how often they've had others tell them about such suspicions. The following provides the results.

Table 3.2.1a: How many people have told you they suspected a child of having harmed someone through witchcraft?

\begin{tabular}{|c|c|c|}
\hline $\begin{array}{l}\text { Number Reporting Child- } \\
\text { Witch Suspicion to Pastor }\end{array}$ & Frequency & Percent \\
\hline None & 173 & $24.3 \%$ \\
\hline 1 or 2 & 177 & $24.8 \%$ \\
\hline $3-5$ & 126 & $17.7 \%$ \\
\hline $6-10$ & 101 & $14.2 \%$ \\
\hline $1-20$ & 48 & $6.7 \%$ \\
\hline $21+$ & 88 & $12.3 \%$ \\
\hline
\end{tabular}

Over three-quarters of respondents $(76 \%)$ report that one or more people had explicitly shared such a suspicion with them, with $12 \%$ reporting that more than twenty people have shared such suspicions with them. Some pastors clarified afterward that the question was potentially ambiguous since people often indirectly signal their suspicions rather than explicitly state them, as the question implies. ${ }^{37}$

The denominational tradition of pastors affected the frequency with which people shared child-witch suspicions with them, where Catholic, Revival, and Africa Independent respondents report receiving somewhat higher levels of verbalized child-witch suspicions than Protestant respondents. ${ }^{38}$ Differences between Catholic, Revival, and AIC respondents were not statistically significant.

Since there is clearly a difference between receiving a report about a suspected child, and actually having first-hand relationships with suspected children, we also asked, "How many children do you personally know that have been accused of having harmed others through witchcraft?" Again, some pastors later suggested the question was ambiguous. One might have had first-hand contact with accused children, but might nonetheless not report "personally knowing" the alleged witch-child. And indeed, evidence from other question responses, suggests this may have been the case. In any case, the following provides the results.

\begin{tabular}{|c|c|c|}
\hline $\begin{array}{l}\text { Number of Accused Children } \\
\text { You Personally Know }\end{array}$ & Frequency & Percent \\
\hline None & 228 & $32.0 \%$ \\
\hline 1 or 2 & 194 & $27.2 \%$ \\
\hline $3-5$ & 111 & $15.6 \%$ \\
\hline $6-10$ & 66 & $9.3 \%$ \\
\hline $11-20$ & 41 & $5.8 \%$ \\
\hline $21+$ & 73 & $10.2 \%$ \\
\hline
\end{tabular}

Two-thirds of pastors $(68 \%)$ reported a first-hand personal relationship with one or more such children, and with $10 \%$ reporting that they personally know more than 20 such children. ${ }^{39}$ While there was great variability within each denominational tradition, denominational tradition nonetheless had a significant but small effect on knowing accused children. ${ }^{40} \mathrm{With}$ both of the above questions, one finds evidence that most pastors have significant first-hand exposure to the child-witch phenomenon, and thus that surveying

\footnotetext{
${ }^{37}$ In societies around the world, people often signal their initial suspicions in indirect ways. And in a context where Congolese law makes it a crime to accuse a child of witchcraft, the tendency to signify through indirect allusion might be even higher. In short, question wording doubtless could have been better.
}

${ }^{38}$ Analysis of variance (ANOVA) indicates that denominational traditions differed significantly on the extent to which people reported child-witch suspicions to pastors $[\mathrm{F}(3,699)=8.70$, $\mathrm{p}<.001]$. A post hoc Tukey test showed that Protestant respondents differed from Catholic respondents at $\mathrm{p}<.01$, from Revival respondents at $\mathrm{p}<.001$, and from Africa Independent respondents at $\mathrm{p}<.05$. The effect size was small $\left[\eta^{2}=.036\right]$. But even controlling for sex, age, educational level completed, and church size, using the general linear model in SPSS, church tradition still had a significant though small effect on how frequently pastors received allegations of childwitchcraft $\left[\mathrm{F}=7.41, \mathrm{p}<.001, \eta_{\mathrm{p}-.032]}^{2}\right.$

${ }^{39}$ A parallel question about accused adults “personally known” to respondents elicited very similar rates.

${ }^{40}$ Analysis of variance (ANOVA) indicates that denominational traditions differed significantly on the extent to which pastors reported personally knowing accused child-witches $[\mathrm{F}(3,699)=6.65, \mathrm{p}<.001]$. A post hoc Tukey test showed that Protestant respondents differed from Revival respondents at $\mathrm{p}<.01$, and from Africa Independent respondents at $\mathrm{p}<.05$. The effect size was small $\left[\eta^{2}=\right.$ .028]. But even controlling for sex, age, church size, and educational level completed, church tradition still had a significant though small effect on how frequently pastors received allegations of child-witchcraft $\left[\mathrm{F}=5.72, \mathrm{p}<.001, \eta_{\mathrm{p}-.025]}^{2}\right.$ 
pastors about their knowledge of the phenomenon makes good sense.

\subsubsection{The Accused by Sex and Age}

The literature on child-witch accusations sometimes suggests that boys are accused far more often than girls. ${ }^{41}$ But others have questioned this. ${ }^{42}$ Cimpric (2010, 17) reports that "no accurate statistical analysis has been carried out to confirm the [supposed] tendency to accuse boys more than girls."

Since pastors are often on the front line of those asked to address child-witch suspicions, we wanted to know, in the experience of these pastors, whether there was a tendency for either boys or girls to be accused more frequently. The following provides the results.

Table 3.2.2a: Among the boys and girls that you personally know who have been accused of being witches, who have been accused most often?

\begin{tabular}{ccc}
\hline Accused Most Often? & Frequency & Percent \\
\hline The Boys More Often Than the Girls & 208 & $29.2 \%$ \\
Boys and Girls Equally as Often & 327 & $45.9 \%$ \\
The Girls More Often Than the Boys & 178 & $25.0 \%$ \\
\hline
\end{tabular}

Nearly half of respondents reported boys and girls being accused at comparable rates, with the other half split nearly evenly between those who think boys are accused more often and those who think girls are. The frequency of child-witch accusations does not differ significantly by gender. By contrast, a parallel question asking whether adult men or women are accused more often, had twice as many respondents answering "women" (38.6\%) as answered "men" (18.7\%), but with many nonetheless claiming equal frequency for both $(42.7 \%)$.

\section{Girl Accused of Witchcraft}

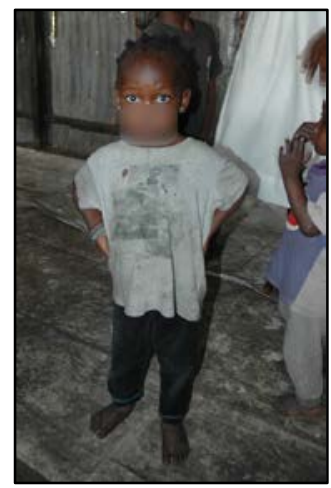

Young girl, said to be a witch, waits her turn for deliverance.

\section{Boy Accused of Witchcraft}

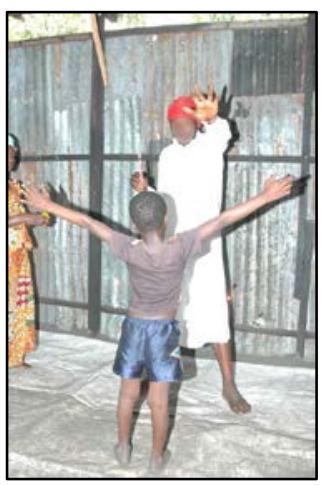

Boy undergoes deliverance by a prophet. May 2017. Photographs by EPED Staff

Prior research suggests that children of all ages get accused, but there is disagreement on which ages are accused most frequently. Yengo (2008) suggests four-toseven-year-olds are accused most frequently, while D'Haeyer (2004), Schnoebelin (2009, 30) and Stobart $(2006,10)$ identify eight-to-fourteen-year-olds as most frequently accused. In our survey, then, we asked pastors to consider child-witch accusations cases they personally know of, and to indicate the age of the youngest accused child, as well as to indicate the average age of the accused.

Table 3.2.2b: In the child-witch accusation cases you know of, when considering the age of those accused, what was ...

\begin{tabular}{ccc}
\hline & Frequency & Percent \\
\hline The Youngest Age Accused? & & \\
$\leq 4$ & 127 & $19.8 \%$ \\
$5-8$ & 202 & $31.6 \%$ \\
$9-12$ & 182 & $28.4 \%$ \\
$13-17$ & 129 & $20.2 \%$ \\
\hline The Average Age Accused? & & \\
Between 1 \& 8 & 257 & $36.0 \%$ \\
Between 9 \& 17 & 456 & $64.0 \%$ \\
\hline
\end{tabular}

One-fifth of respondents reported knowledge of accused children four-years-old or younger. Half reported knowing accused children less than nine. Slightly over a third estimate the average age of the accused as less than nine, while nearly two-thirds place the average above that. Our results are compatible with the peak ages others have identified as 8 to 14 .

\footnotetext{
${ }^{41}$ D'Haeyer 2004; Mayneri 2017; See also The Impact of accusations of Witchcraft against Children in Angola. An Analysis From The Human Rights Perspective. UNICEF, p. 21.
}

${ }^{12}$ De Boeck 2000; Cahn 2005; Schnoebelin 2009, 30; Ballet, Lallau and Dumbi 2019, 8. 


\subsubsection{What the Children Are Accused of When Labeled a Witch}

Witch suspicions emerge against the backdrop of misfortunes. And families in Kinshasa encounter a wide variety of misfortunes. Even those with educational credentials, gifting, and social connections sometimes find themselves with perpetual unemployment. Travel hopes are thwarted. Married couples face unwanted fertility problems. Illnesses hinder employment and require medical expenditures that further drain scarce financial resources. And family members die.

With misfortunes on all sides, people come to feel "blocked" and suspect the secret presence in their family of a malign "witch." And when a child is accused of being this witch, the central charge against them is that they have caused their family's misfortunes through some malignant and mysterious power.

While families often bring their children with their suspicions to Kinshasa pastors, "it is important to note," according to the anthropologist Filip de Boeck (2009, 131), "that church leaders themselves are most often not the source of witchcraft allegations against children, [but] merely confirm (and thereby legitimize) accusations and suspicions which already exist within the child's family environment." ${ }^{\$ 3}$ By turning "already existing allegations into an official diagnosis," according to de Boeck, such pastors are able to then offer an "alternative solution to the problem." The point to bear in mind at this stage of the analysis is that the specific harms which family members attribute to child-witches do not differ appreciably from the misfortunes that pastors also attribute to witches, as evidenced by the writings of Kinshasa pastors on the subject. ${ }^{4}$ For example, the Reverend Apostle Wallo Mutsenga Malachie (pastor of one of Kinshasa's largest megachurches), who reports delivering scores of witchesboth children and adults, wrote a brochure (2013) on witchcraft for use in his church's "School of Deliverance." He writes that witches have great power, as evidenced in their ability to transform themselves into "a mosquito, rat, cockroach, or lion." Their principal goal is to bring misfortune on people, families, relationships, and projects. Witches, he tells his readers, divide families, cause the unemployment of family members, "block" family members from "finding openings that would enable them to flourish," cause family poverty, cause divorces, cause infertility, cause multiple family illnesses contributing to poverty and misery, bring death to family members, and cause family members "to remain single"-unable to find a spouse.

In the following table, respondents report on the frequency with which various sorts of harm are attributed to the children said to be witches.

\begin{tabular}{|c|c|c|}
\hline $\begin{array}{l}\text { Harm Allegedly Caused } \\
\text { Through Witchcraft }\end{array}$ & Frequency & Percent \\
\hline Financial Difficulties & 530 & $74.3 \%$ \\
\hline Sickness & 520 & $72.9 \%$ \\
\hline Death & 517 & $72.5 \%$ \\
\hline Consistent Bad Luck & 478 & $67.0 \%$ \\
\hline Sterility/Infertility & 454 & $63.7 \%$ \\
\hline Impotence & 262 & $36.7 \%$ \\
\hline
\end{tabular}

Nearly three-quarters of respondents report knowing child accusation cases where the child allegedly caused financial difficulties, with a similar number allegedly causing sickness, and a similar number, death. Over two-thirds report knowing cases where the charge was for causing "consistent bad luck," with nearly two-thirds reporting the charge of having caused sterility/infertility, and over a third the charge of having caused impotence.

The above items correlate highly with each other, forming a cluster, such that the presence of any one item is likely to be accompanied by other items in the cluster. In other words, respondents who mentioned one of these items were likely to mention others in this list as well. Statistically, they may be added together as a composite measure, a scale, of "Afflictions Allegedly Caused Through Witchcraft.” ${ }^{45}$

Denominational tradition had a medium impact on reported allegations that children cause these afflictions through witchcraft, with Catholic pastors, Revival pastors, and AIC pastors reporting higher levels of such allegations than Protestant pastors, but with Catholic, Revival, and AIC pastors not differing statistically from each other. ${ }^{46}$

${ }^{43}$ By contrast, Hanson $(2013,8)$ reported that "research carried out in 2010 [in the Niger Deltal shows that in 31 percent of cases the child was accused of witchcraft by a pastor in the first place.” The possible role of pastors in fostering witch accusations, or even initiating them, merits further study.

"Balibuno Zahinda Byamungu 2013; Kalonji Mbuyi 2003, 2007, 2010, 2014; Kigalu Mangala 2008, 2013; Wallo Mutsenga 2013.

${ }^{45}$ As a scale these have a Cronbach's Reliability Alpha of .861.

${ }^{46}$ Analysis of variance (ANOVA) indicates that denominational traditions had a significant effect on the extent to which these misfortunes are attributed to child-witches $[\mathrm{F}(3,699)=13.39, \mathrm{p}<.001]$. A post hoc Tukey test showed that Protestant respondents differed from Revival respondents at $\mathrm{p}<.001$, and from Catholic and Africa Independent respondents at $\mathrm{p}<.05$. The effect size was 


\subsubsection{Factors Understood as Evidence of the Identity of a Child-Witch}

While mysterious misfortunes lead people to infer the presence of a witch at work, the actual identity of the witch is inferred on other grounds. Since witches are thought to operate in a night world, dreams provide one sort of evidence. ${ }^{47}$ If someone dreams that another family member is attacking them, according to Revival church Pastor Jules Kigalu Mangala (2008, 89), this signals that the person dreamed about is a witch. Alternatively, a child's reported dreams can provide evidence that they are a witch. According to pastor Wallo Mutsenga, many witches do not even know they are witches-but their dreams provide evidence they are unconscious witches. Dreams that indicate one is a witch include dreams of flying, of being naked, of doing something wrong, of visiting a wonderful and unknown world, of being older than one truly is, of cultivating fields, of giving birth, of nursing, of bathing and caring for young children, and of eating meat (Wallo Mutsenga 2013). In Dr. Opoku Onyinah's extensive research on witchcraft among Christians in Ghana, he reports that those claiming to be victims of witchcraft frequently appeal to what their own dreams "revealed," and that even those "confessing" to witchcraft, often confess simply based on "the assumption that they probably committed the alleged crime in their dreams" $(2012,53)$.

In Kinshasa, a wide variety of behaviors are thought of as likely indicators of witchcraft. For example, as taught by Revival megachurch pastor Wallo Mutsenga (2013), indicators of witchcraft include weight loss, bedwetting, and "odd hand, eye, mouth, or tongue gestures.” Involvement in the night world of witchcraft is evident in deep unmoving sleep, talking in one's sleep, waking up tired, sore, and lethargic with apathy over the affairs of waking life. Forgetfulness, depression, and bad hygiene provide further evidence of having a primary focus on the night world of witchcraft. As Wallo Mutsenga notes, "witches are often ugly," with "elements that make them disgusting (scabies, slobber, filth.)" Under a logic of exchange, witches are understood to achieve great power in the night world by sacrificing this-worldly health and power. Thus someone with a handicap, a disability, anemia, an illness, or even mental defect may be understood as having actively chosen these outcomes as part of a conditional exchange to acquire great witch power. Witches are often sick with odd and complicated illnesses. As children, they develop slowly. As adults, they age quickly (Mutsenga 2013). Revival Pastor Jean Marie Kalonji Mbuyi (2003, 51ff) identifies similar sorts of evidence for witchcraft and adds that child-witches like dirt and resist baths because of a desire to retain their distinctive smell. He says that if a child (or adult) falls asleep during prayer or sermon, this provides evidence they are a witch. Pastor Jules Kigalu Mangala (2008, 89-93) repeats the same symptoms of unconscious witchcraft that Wallo Mutsenga does, but also provides lengthier discussions of how sexual and procreative disorders can be evidence that an adult is an unconscious witch. ${ }^{48}$

Since family members, such as parents, are normally thought to have the best interests of their children in mind, when a family member nonetheless identifies their child as a witch, this is sometimes felt to carry unusual weight. Traditionally, diviners were felt to have the supernatural power to sense who was a witch. Thus their word was trusted. Today, many Christian pastoral leaders are likewise felt to have supernatural insight on the identity of witches. So when a family member, a diviner, or a pastor, signals that they believe a child is a witch, this itself counts as plausible evidence that they are.

Finally, an actual confession of witchcraft is felt to hold special evidentiary weight. And when a confessing child then identifies someone else as also a witch, this identification likewise holds evidentiary weight. In the following table, respondents report on their own experience of the prevalence of appeals to each sort of evidence.

medium $\left[\eta^{2}=.055\right]$. Even controlling for sex, age, educational level completed, and church size, church tradition still had a significant and moderate effect on how frequently afflictions were attributed to child-witches $\left[\mathrm{F}=11.70, \mathrm{p}<.001, \eta_{\mathrm{p}-.049]}^{2}\right.$.

${ }^{47}$ Pastor Kalonji Mbuyi $(2003,51)$ reports that "the dreams that God gives us about our children sometimes can be a language of revelation" letting us know our child is a witch. A dream of losing a child while on a journey, he says, should be interpreted as signaling that one has lost this child to witchcraft.

${ }^{18}$ He explains that disorders of everyday life are by-products of witch activities in the night world: "A sexual organ that is used in the
world of darkness will lose its vigor, quality, taste, and even depth of action." Sexual impotence, frigidity, sterility, sexual diversion
tendencies (masturbation, homosexuality, pedophilia, incest), disgust of marriage, prolonged singleness, sexual incontinence or lack
of self-control in the sexual domain, gynecological illnesses of all sorts (STDs, resistances, blockage, cysts, fibromyalgia, perturbation
within menstrual cycles, premature stoppage of periods, prostate problems), urinary incontinence, disgust of natural sexual
intercourse, etc. all provide evidence of unconscious witchcraft due to sexual involvements in the night world of witchcraft (121-122). 
Table 3.2.4: In the child accusation cases that you know of, which of the following factors influenced people to conclude that the child was truly a witch?

\begin{tabular}{|c|c|c|}
\hline $\begin{array}{l}\text { Factors Influencing People to } \\
\text { Conclude a Child is a Witch }\end{array}$ & Frequency & Percent \\
\hline $\begin{array}{l}\text { A Child's Physical Defect, } \\
\text { Illness, or Handicap }\end{array}$ & 195 & $27.3 \%$ \\
\hline The Child Wet Its Bed & 252 & $35.3 \%$ \\
\hline $\begin{array}{l}\text { Suspicious Behavior of the } \\
\text { Child }\end{array}$ & 392 & $55.0 \%$ \\
\hline Another Person Who & & \\
\hline $\begin{array}{l}\text { Confessed to Witchcraft } \\
\text { Identified the Child as a } \\
\text { Witch }\end{array}$ & 393 & $55.1 \%$ \\
\hline $\begin{array}{l}\text { A Parent or Family Member } \\
\text { Identified the Child as a } \\
\text { Witch }\end{array}$ & 417 & $58.5 \%$ \\
\hline $\begin{array}{l}\text { Another Child Identified Him } \\
\text { or Her as a Witch }\end{array}$ & 323 & $45.3 \%$ \\
\hline $\begin{array}{l}\text { A Non-Christian Diviner } \\
\text { Identified the Child as a } \\
\text { Witch }\end{array}$ & 375 & $52.6 \%$ \\
\hline $\begin{array}{l}\text { A Pastor, Prophet, or } \\
\text { Intercessor Identified the } \\
\text { Child as a Witch }\end{array}$ & 489 & $68.6 \%$ \\
\hline A Dream & 446 & $62.6 \%$ \\
\hline $\begin{array}{l}\text { The Child Confessed to Being } \\
\text { a Witch }\end{array}$ & 516 & $72.4 \%$ \\
\hline
\end{tabular}

Slightly over a quarter of respondents (27\%) report a child's defect, illness, or handicap as having been appealed to as evidence that they were a witch. More than a third (35\%) report bedwetting used as evidence, with over half (55\%) identifying unspecified "suspicious behavior" as evidence. When a child is accused of witchcraft by a "confessed witch" $(55 \%)$, or by a parent or family member (58\%), or by a non-Christian diviner (53\%), these were considered evidence of guilt in cases observed by over half of respondents. Over two-thirds of respondents $(69 \%)$ reported that the testimony of a pastor, prophet, or intercessor was treated as evidence. Nearly two thirds (63\%) report an evidentiary appeal to dream content. And the most common evidence appealed to, as seen in the $72 \%$ of pastors reporting this, is the confession of children themselves.

The above items correlate highly with each other, forming a cluster, such that the presence of any single item is likely to be accompanied by other items in the cluster. That is, respondents who mentioned any one of these items were very likely to mention others as well. Statistically, they may be added together as a composite measure, an "Evidences a Child is a Witch Scale." There were no significant differences between pastors of different denominational traditions in the extent to which these items were considered evidence that a child is a witch. However, respondents who reported high levels of "Afflictions Allegedly Caused Through ChildWitchcraft," also reported high levels of appeal to "Evidences a Child is a Witch." The correlation between the two is moderately strong. ${ }^{50}$

\subsubsection{Consequences for the Accused Child}

When children are accused of having caused the affliction and death of others, it makes sense that such a charge would have social consequences to the child. Those who've studied the phenomenon note that accused children are feared and avoided, mistreated in their own homes, beaten, driven from their homes, and sometimes killed. ${ }^{51}$ Many are also taken to pastors both to confirm the suspicions and to seek deliverance. The following table shows the frequency with which pastors observed various outcomes for the child.

Table 3.2.5a: In the child-accusation cases that you know of, what were the consequences for the accused child?

\begin{tabular}{lcc}
\hline $\begin{array}{l}\text { Consequences for the Accused } \\
\text { Child [50-54] }\end{array}$ & Frequency & Percent \\
\hline $\begin{array}{l}\text { People Avoided Contact } \\
\text { with the Child }\end{array}$ & 600 & $84.2 \%$ \\
$\begin{array}{l}\text { The Child was Driven } \\
\text { from Home \&/or }\end{array}$ & 414 & $58.1 \%$ \\
$\quad \begin{array}{l}\text { Neighborhood } \\
\text { The Child was Physically }\end{array}$ & 436 & $61.2 \%$ \\
$\quad$ Harmed & & \\
$\quad \begin{array}{l}\text { The Child was Killed } \\
\text { The Child was Brought to } \\
\quad \text { Church for }\end{array}$ & 544 & $76.3 \%$ \\
$\quad$ Deliverance & & \\
\hline
\end{tabular}

Over half (58\%) know of cases where accused children were driven from their home or community, with a slightly higher number (61\%) reporting physical harm being done to them, and $84 \%$ report that people avoided contact with the child. For vulnerable children, such as orphans, social avoidance can be hugely consequential. Thirteen percent of pastors report personally knowing of an accused child being killed. Three-quarters $(76 \%)$ know cases of children being brought to a church for deliverance.

\subsection{Pastoral and Church Responses to Child-Witch Accusations}

In Kinshasa, as we've seen, when families suspect a child of witchcraft, it is often to church leaders that they turn. And church leaders respond in a variety of ways. One possible outcome of a child being brought to a

\footnotetext{
${ }^{19}$ As a scale these have a Cronbach's Reliability Alpha of .791.

${ }^{50} \mathrm{r}=.459, \mathrm{p}<.001$.
}

${ }^{51}$ Bussien et. al. 2011, 9; Cimpric 2010, 40ff: De Boeck, 2009, 131; Molina 2005, pp. $20 \mathrm{ff}$. 
church under suspicion of witchcraft is that church leaders endorse the accusation, and endeavor to resolve the problem through some form of deliverance practice.

The anthropologist Filip De Boeck (2009, 131-132) indicates that often church leaders simultaneously confirm the witch diagnosis and offer a solution to the problem, removing accused children from "the (sometimes extreme) physical and psychological violence they undergo in their own family" to a churchbased "therapeutic 'healing' space." Here children undergo a period of time where they are secluded/ quarantined (often with other accused children), and subjected to purgatives (laxatives and emetics), to fasting, and to regular interrogations encouraging them to confess. "In collaboration with the leaders of the church, the children slowly construct a narrative about how they became witches," eventually leading to a public confession and deliverance, with the "hope of facilitating the reintegration of the cleansed witch-child within its family." De Boeck reports, however, that family members are often unwilling to readmit a child understood to have been a witch back into their family. All too frequently, he contends, such "young children are forced to take to the street in the end."

Based on prior literature, and on advice from EPED staff, we inquired about several church-based childwitch deliverance practices sometimes reported. ${ }^{52} \mathrm{We}$ asked, "In the cases you personally know of where a pastor, prophet, or intercessor was involved in the deliverance of children accused of being witches, which of the following did they do as part of the deliverance?

\section{Table 3.3a Traditional Deliverance Practices}

\begin{tabular}{lcc}
\hline $\begin{array}{l}\text { Done to Child as Part of } \\
\text { Deliverance }\end{array}$ & Frequency & Percent \\
\hline Require the Child to Fast & 327 & $45.9 \%$ \\
Prod the Child to Confess & 240 & $33.7 \%$ \\
Make the Child Drink a & 208 & $29.2 \%$ \\
$\quad$ Special Potion & & \\
Induce the Child to Vomit & 194 & $27.2 \%$ \\
Shave the Child's Head & 197 & $27.6 \%$
\end{tabular}

\begin{tabular}{lcc}
$\begin{array}{l}\text { Pass the Child through } \\
\text { Fire }\end{array}$ & 110 & $15.4 \%$ \\
Cause the Child to Bleed & 77 & $10.8 \%$ \\
\hline
\end{tabular}

A little less than half of the respondents (46\%) report that deliverances of child-witches which they personally know of required the child to fast. A third (34\%) report that the child was prodded to confess. Between a quarter and a third of respondents reported that the child was required to drink a potion (29\%), was induced to vomit (27\%), or had their head shaved (28\%). And lower numbers reported that the child was required to pass through fire (15\%) or was bled (11\%). ${ }^{53}$ Each of the above practices has precursors in traditional Congolese cultures. While some of these have no parallels with anything in Scripture, at least two of these do. But while fasting does occur as a biblical practice, in Scripture fasting seems to be practiced by the person who is praying, not the person who is being prayed over, and certainly does not involve a mandate for coerced fasting of individuals being delivered from witchcraft. Similarly, confession is a common practice both in the Bible and in Congolese cultures, although the effort to elicit a confession from people accused of witchcraft only explicitly occurs in traditional Congolese cultures, not in Scripture. The above practices, then, form a cluster of traditional deliverance practices that co-vary together. In other words, respondents who mentioned any one of these items were very likely to mention others as well. Thus these can be combined as a "Traditional Deliverance Practices Scale." ${ }^{\text {st }}$

Taken as a whole, denominational tradition has a small, but significant association with "Traditional Deliverance Practices," with both Catholic and Revival respondents scoring higher on this scale than Protestants. ${ }^{55}$ While AIC respondents scored as high as Revival respondents on these practices, because of their smaller sample size this difference from Protestant respondents did not register as statistically significant.

It is worth pointing out that while most pastors reported first-hand knowledge of deliverances of

\footnotetext{
${ }^{52}$ Aguilar Molina (2005, 30ff) for example, reports anal flushing, purging through the ingestion of oils and other substances, cuttings with razor blades, the administration of dangerous substances to the eyes, denial of food and water, and genitals being caressed.

${ }^{53}$ We also asked about whether the child was "sexually molested" in deliverance. Forty-three respondents affirmed this being present in cases they personally know of $(6 \%)$. But in retrospect, we realize that this question was poorly worded, framed in terms that might have been denied by those most likely to be involved in any deliverance practices involving sexual contact. And statistically this item did not strengthen the list as a scale. So we did not include it in our scale.

${ }^{51}$ Giving a Cronbach's Alpha of .784.

${ }_{55}^{55}$ Analysis of variance (ANOVA) indicates that denominational traditions had a small but significant effect on the presence of these deliverance practices $[\mathrm{F}(3,699)=6.04, \mathrm{p}<.001]$. A post hoc Tukey test showed that Protestant respondents differed from Revival respondents and from Catholic respondents at $\mathrm{p}<.05$. The effect size was small $\left[\eta^{2}=.025\right]$. Even controlling for sex, age, educational level completed, and church size, church tradition still had a significant but small effect on these deliverance practices $[\mathrm{F}=3.60$, $\mathrm{p}<.05$, $\left.\eta_{\mathrm{p}-0}^{2}-016\right]$
} 
children for witchcraft, not a single one of the practices listed above was identified by more than half of the respondents as present in the cases they were familiar with. A partial explanation, based on De Boeck's description, might be that the above practices generally happen in relatively private settings managed by a small sub-set of church leaders, practices no longer present in what are sometimes concluding public church-wide confession and deliverance events. The final confession and deliverance are likely to be most compelling to an audience when confessions seem voluntary and spontaneous, rather than when confessions are clearly responsive to coercive practices of elicitation. Thus church leaders whose only exposure to deliverance is in a final front-stage performance might be less aware of these back-stage practices than leaders more centrally involved throughout. That is, many such leaders may simply not be aware of the preparatory practices that in fact precede the public confessions they observe. But it is also possible that these practices are not present, or only minimally present, in many deliverances. Aguilar Molina (2005, 30) acknowledged that some pastors report "using only prayer as a means of deliverance," a possibility we failed to explore in our survey. Some Congolese pastors on deliverance explicitly critique traditional deliverance practices such as those above as culturally derived and nonbiblical, and seemingly advocate primarily prayer and "laying on of hands." For example, one of the most influential local authors in Kinshasa on the topic of witchcraft deliverance is the Revival Church pastor, Jean Marie Kalonji Mbuyi, himself a leading advocate of deliverance for witches, but who nonetheless explicitly critiques as illegitimate what he reports are common deliverance practices in Kinshasa.

Prayer for Alleged Witch

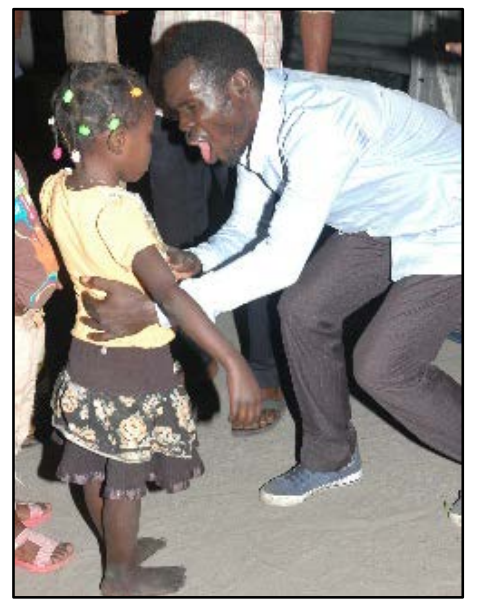

May 2017, EPED Photo
Specifically he repudiates any practice involving purging, burning, cutting of hair, drinking or washing with special water, drinking oil, rubbing with oil, hitting the witch with an iron rod, making the witch stare at the sun from sunrise to sunset, and putting hot pepper in the witches eyes or ears (Kalonji Mbuyi 2003, 101; 2010, 47). Unfortunately, he does not provide descriptive detail on how he himself conducts deliverance sessions. Future research should focus on providing a more careful descriptive analysis of prayer patterns in churches that renounce traditional cultural practices.

In our survey, we asked respondents to characterize the frequency within their own churches with which various patterns related to alleged child witches are present. When we examined the results statistically using factor analysis, we discovered two clusters of attributes for which each item in the respective cluster was closely correlated with each of the other items in that cluster, and which thus can be said to form a scale. The first cluster features items that we label here as involving a "Witch Diagnosis and Deliverance Paradigm.”

Table 3.3b Witch Diagnosis and Deliverance Paradigm

\begin{tabular}{|c|c|c|c|}
\hline In My Church: & & Frequency & Percent \\
\hline \multirow{4}{*}{$\begin{array}{l}\text { Deliverance of Child- } \\
\text { Witches is Practiced }\end{array}$} & Never & 145 & $20.3 \%$ \\
\hline & Sometimes & 299 & $41.9 \%$ \\
\hline & Often & 182 & $25.5 \%$ \\
\hline & Always & 87 & $12.2 \%$ \\
\hline \multirow{4}{*}{$\begin{array}{l}\text { Sermons Teach that } \\
\text { Child-Witches Harm } \\
\text { Others by their } \\
\text { Supernatural Powers. }\end{array}$} & Never & 212 & $29.7 \%$ \\
\hline & Sometimes & 312 & $43.8 \%$ \\
\hline & Often & 134 & $18.8 \%$ \\
\hline & Always & 55 & $7.7 \%$ \\
\hline \multirow{4}{*}{$\begin{array}{l}\text { Certain Church Leaders } \\
\text { are Believed to have the } \\
\text { ability to Identify Who } \\
\text { is or is Not a Witch }\end{array}$} & Never & 164 & $23.0 \%$ \\
\hline & Sometimes & 332 & $46.6 \%$ \\
\hline & Often & 143 & $20.1 \%$ \\
\hline & Always & 74 & $10.4 \%$ \\
\hline \multirow{4}{*}{$\begin{array}{l}\text { Church Members } \\
\text { Confess to Being } \\
\text { Witches }\end{array}$} & Never & 260 & $36.5 \%$ \\
\hline & Sometimes & 366 & $51.3 \%$ \\
\hline & Often & 79 & $11.1 \%$ \\
\hline & Always & 8 & $1.1 \%$ \\
\hline \multirow{4}{*}{$\begin{array}{l}\text { Children Confess to } \\
\text { Being Witches }\end{array}$} & Never & 161 & $22.6 \%$ \\
\hline & Sometimes & 429 & $60.2 \%$ \\
\hline & Often & 108 & $15.1 \%$ \\
\hline & Always & 15 & $2.1 \%$ \\
\hline
\end{tabular}

Eighty percent of respondents report that deliverance of child-witches is practiced in their church, but with varying levels of frequency. Over two-thirds of respondents $(70 \%)$ report that sermons in their church teach that misfortunes are caused by the supernatural power of child-witches, again with varying frequencies. Over three-quarters of respondents $(77 \%)$ report that church leaders in their church are assumed to have the power to know who is or is not a witch, again with variability. Nearly two-thirds $(64 \%)$ report that church members in their church sometimes confess to being witches, with more than three-quarters $(77 \%)$ reporting 
that children in their church confess to being witches, though again with varying levels of frequency. Statistically, the above items form part of a larger package. The "deliverance of child witches" is justified by sermons that explicitly defend the idea that misfortunes are sometimes caused by the evil power of child witches, and underpinned by the belief that some church leaders truly have the ability and authority to identify such child witches. And the normative requirement of confession is frequently part of the ritual process within deliverance ceremonies. Statistically, they form a scale, ${ }^{56}$ for a "Witch Diagnosis and Deliverance Paradigm.”

Denominational tradition had a small but significant impact on the extent to which respondents' churches exemplified the attributes of the Witch Diagnosis and Deliverance Paradigm. Specifically, AIC churches scored higher on this paradigm than any of the other church traditions at a significant level. ${ }^{57}$ But the other three traditions did not differ from each other at a significant level. Whether a church "tended toward Pentecostal doctrine" also had a small but significant positive effect on support for the child deliverance paradigm. $^{58}$

To be clear, as the above table shows, on each item listed, there is great variability among churches. Some churches "never" practice deliverance of child-witches, and others do so frequently. But this variability exists within each denominational tradition far more than between denominational traditions. In each denominational tradition, and on each side of the pentecostal vs. non-pentecostal divide, ${ }^{59}$ there are many churches that "never" practice such deliverance and others that "often" or "always" do so. But if one looks at the average responses of each denominational tradition, and at the average responses for churches inclined towards Pentecostal doctrine vs. those that are not, the averages tend to differ only weakly, or not at all. We will have more to say about this in our concluding remarks.

Pastoral training was also associated with the extent to which a church scored high on the Witch Diagnosis and Deliverance Paradigm. Specifically, churches whose pastors had a formal theological four-year diploma or above were less likely to affirm the child deliverance paradigm than churches where pastors were simply trained informally in congregational settings, or trained in a two or three year Bible institute. $^{60}$

The cluster of practices in the "Witch Diagnosis and Deliverance Paradigm" assumes that the child is truly a powerful witch contaminated by a great moral evil that must be combatted and removed. But there is a second cluster of practices predicated on the contrasting perception that the accused is a weak and vulnerable child in need of protection and assistance. These questions are closely correlated with each other statistically, representing a "Child Protection Paradigm."

${ }^{36}$ The "Witch Diagnosis and Deliverance Paradigm," as measured by these questions, forms a scale with a Cronbach's Reliability Alpha of .718. And when the questions are combined as a scale any given church can be scored from 0 (when "never" is answered for all five questions), to 15 (when "always" is the consistent answer).

${ }^{57}$ Analysis of variance (ANOVA) indicates that denominational tradition had a small but significant effect on the "Witch Diagnosis and Deliverance Paradigm $[\mathrm{F}(3,699)=4.45, \mathrm{p}<.01]$. A post hoc Tukey test showed that AIC respondents differed from Protestant respondents at $\mathrm{p}<.01$, and from Catholic and Revival respondents at $\mathrm{p}<.05$. The effect size was small $\left[\eta^{2}=.019\right]$. After controlling for sex, age, educational level completed, and church size, church tradition still had a significant but small effect on patterns related to the Witch Diagnosis and Deliverance Paradigm $\left[\mathrm{F}=6.13, \mathrm{p}<.001, \eta_{\mathrm{p}-.026]}^{2}\right.$

${ }^{58}$ Analysis of variance (ANOVA) indicates that Pentecostal doctrine had a significant effect on the child deliverance paradigm [F $(1$, $711)=13.47, \mathrm{p}<.001]$. The effect size was small $\left[\eta^{2}=.022\right]$. After controlling for sex, age, denominational tradition, and church size, Pentecostal doctrine was still positively associated with the embrace of the child deliverance paradigm $\left[F=11.67, \mathrm{p}<.001, \eta_{\mathrm{p}-}^{2} .017\right]$.

${ }^{59}$ "Recall that within each tradition, there are pastors that respond affirmatively to the question "Does your church tend towards Pentecostal doctrine?” and others that did not-see 3.1.4).

${ }^{60}$ Analysis of variance (ANOVA) indicates that pastoral education had a significant small effect on churches' embrace of the child deliverance paradigm $[\mathrm{F}(2,710)=7.660, \mathrm{p}<.001]$. A post hoc Tukey test showed that churches whose pastors had a four year theological diploma or above, differed from churches whose pastors were training only in ministry at $\mathrm{p}<.01$ and from pastors with only a 2 or 3 year Bible institute education at $\mathrm{p}<.01$. The effect size was small $\left[\eta^{2}=.021\right]$. After controlling for sex, age, denominational tradition, and church size, using the general linear model in SPSS, pastoral training was still positively associated with the embrace of the child protection paradigm $\left[\mathrm{F}=3.70, \mathrm{p}<.05, \eta_{\mathrm{p}-0}^{2}(11]\right.$. 
Table 3.3c Child Protection Paradigm

\begin{tabular}{|c|c|c|c|}
\hline $\begin{array}{l}\text { In My Church, Accused } \\
\text { Children Are... }\end{array}$ & & Frequency & Percent \\
\hline \multirow{4}{*}{$\begin{array}{l}\text { Defended from Witch } \\
\text { Accusations }\end{array}$} & Never & 200 & $28.1 \%$ \\
\hline & Sometimes & 270 & $37.9 \%$ \\
\hline & Often & 152 & $21.3 \%$ \\
\hline & Always & 91 & $12.8 \%$ \\
\hline \multirow{4}{*}{$\begin{array}{l}\text { Provided with Medical } \\
\text { Assistance }\end{array}$} & Never & 189 & $26.5 \%$ \\
\hline & Sometimes & 392 & $55.0 \%$ \\
\hline & Often & 77 & $10.8 \%$ \\
\hline & Always & 55 & $7.7 \%$ \\
\hline \multirow{4}{*}{$\begin{array}{l}\text { Provided with Educational } \\
\text { Assistance }\end{array}$} & Never & 209 & $29.3 \%$ \\
\hline & Sometimes & 331 & $46.4 \%$ \\
\hline & Often & 102 & $14.3 \%$ \\
\hline & Always & 71 & $10.0 \%$ \\
\hline \multirow{4}{*}{ Provided with Counseling } & Never & 178 & $25.0 \%$ \\
\hline & Sometimes & 353 & $49.5 \%$ \\
\hline & Often & 106 & $14.9 \%$ \\
\hline & Always & 76 & $10.7 \%$ \\
\hline \multirow{4}{*}{$\begin{array}{l}\text { Provided with Personalized } \\
\text { Pastoral Care for the } \\
\text { Wholistic Development } \\
\text { of Children }\end{array}$} & Never & 206 & $28.9 \%$ \\
\hline & Sometimes & 279 & $39.1 \%$ \\
\hline & Often & 131 & $18.4 \%$ \\
\hline & Always & 97 & $13.6 \%$ \\
\hline \multirow{4}{*}{ Placed in Foster Families } & Never & 288 & $40.4 \%$ \\
\hline & Sometimes & 324 & $45.4 \%$ \\
\hline & Often & 57 & $8.0 \%$ \\
\hline & Always & 44 & $6.2 \%$ \\
\hline
\end{tabular}

Seventy-two percent of respondents indicate that children accused of witchcraft in their church are, at least sometimes, defended against the accusation, although at variable rates. For example, only $13 \%$ report that such child-witch accusations are always contested. And 28\% report that child-witch accusations in their church are never contested. Similarly, a high number report, at least sometimes, providing accused children with medical assistance (73\%), educational assistance (71\%), counseling (75\%), "personalized pastoral care for the holistic development of children" (71\%), and placement in foster families (60\%). On each item, there is significant variability in frequency from "never" to "always." But the above items form a cluster statistically correlating with each other to a high degree, and thus forming a scale. ${ }^{61}$ That is, churches that provide one of these forms of assistance is highly likely to provide others of these forms of assistance.

The survey also asked about the extent to which respondents' churches facilitate family reinsertions of accused children, with only $17 \%$ never doing so up to $25 \%$ "always" doing so. Eighty-three percent report that their churches practice family reinsertion at least sometimes. But factor analysis did not identify this question as part of the Child Protection Scale. In all likelihood, this is because, as De Boeck observes, even churches emphasizing the "Witch Diagnosis and Deliverance Paradigm" conceptualize their goal as resulting in family reinsertion. So, in principle, all approaches aspire to family reinsertion. But statistically, the practice of family reinsertion is correlated positively at a moderate level with the Child Protection Paradigm ${ }^{62}$ and is not correlated either positively or negatively with the Witch Diagnosis and Deliverance Paradigm. ${ }^{63}$ That is, churches scoring high on the child protection scale are more likely to practice family reinsertion than churches that score low on this scale. And churches that score high on the Witch Diagnosis and Deliverance Scale do not practice family reinsertion at either a higher or lower level than churches that score low on this scale.

Sixty-four percent of all respondents reported that their church had "a specific program on positive parenting." Those churches scoring high on the Child Protection Paradigm were significantly more likely to report having such a program on positive parenting. ${ }^{64}$ Sixty-eight percent of respondents reported that their church had "a child-protection policy." Again churches scoring high on the child protection paradigm were significantly more likely to have such a formal child protection policy. ${ }^{65}$

Denominational tradition had a medium and significant impact on the extent to which respondents' churches exemplified the attributes of the Child

${ }^{61}$ The "Child Protection Paradigm," as measured by these questions, forms a scale with a Cronbach's Reliability Alpha of .794. When the questions are combined as a scale any given church can be scored from 0 (when "never" is answered for all six questions), to 18 (when "always" is the consistent answer).

${ }^{62} \mathrm{r}=.319, \mathrm{p}<.01$

${ }^{63} \mathrm{r}=-.044, \mathrm{p}=.236$.

${ }^{61}$ Analysis of variance (ANOVA) indicates that the Child Protection Paradigm was associated with having a program in positive parenting $[\mathrm{F}(1,711)=35.54, \mathrm{p}<.001]$. The effect size was medium $\left[\eta^{2}=.048\right]$. After controlling for sex, age, educational level completed, church size, and denominational tradition, the Child Protection Paradigm still had a significant and medium-small effect on having a program in positive parenting $\left[\mathrm{F}=31.01, \mathrm{p}<.001, \eta_{\mathrm{p}-.043]}^{2}\right.$

${ }^{65}$ Analysis of variance (ANOVA) indicates that the Child Protection Paradigm was associated with having a child protection policy $[\mathrm{F}(1,711)=59.58, \mathrm{p}<.001]$. The effect size was medium $\left[\eta^{2}=.077\right]$. After controlling for sex, age, educational level completed, church size, and denominational tradition, the Child Protection Paradigm still had a significant and medium effect on having a child protection policy $\left[\mathrm{F}=41.65, \mathrm{p}<.001, \eta_{\mathrm{p}-0}^{2} .057\right]$ 
Protection Paradigm. Specifically, Catholic churches scored higher on this paradigm than the other three traditions, at a significant level. And Protestant churches also scored higher than Africa Independent churches. ${ }^{66}$ However, Revival Churches did not differ at a significant level from either Protestant or AIC churches ${ }^{67}$ As above, individual churches within each denominational tradition had far greater variability than did denominational traditions as a whole in comparison with each other. Within each denomination, a sizeable number of churches scored high on this scale, and a sizeable number scored low.

The pastoral training of respondents was significantly but weakly associated with the extent to which their church scored high on the Child Protection Paradigm. Specifically, churches whose pastors had a formal theological four-year diploma or above were more likely to affirm the Child Protection Paradigm than pastors simply trained in ministry, or trained in a two or three year Bible Institutes. ${ }^{68}$

Finally, while the above cluster of traits within each scale is tightly correlated with each other, the Witch Diagnosis and Deliverance Paradigm and the Child Protection Paradigm are not empirically correlated, either positively or negatively. That is, how a church scores on one scale is not predictive of how they will score on the other. A church can score high on both scales, low on both scales, or high on one and low on the other. ${ }^{69}$ Apparently, many people are responsive both to the view that some children are vulnerable, weak, and subject to being falsely accused, as well as to the possibility that other children represent dangerous and powerful evil. Or perhaps within some churches one finds a significant group of church members responding one way, and another significant group responding the other.

\subsection{Pastoral Remuneration and Child-Witch Deliverance Ministries}

Researchers on child witchcraft commonly report that pastors ask families either for money or for other material goods (such as for sheets of aluminum roofing for the church), in exchange for child witch deliverance. And our own interviews often confirmed the pattern, as when Pastor Jean above, commented: "Parents were bringing me money because every deliverance requires a special offering. Every work generates abundance. I had a job and it required remuneration. A payment was needed for the work to go forward. This was also getting me into an acceptable social standing, financially speaking." Aguilar Molina (2005, 28ff) reports on his systematic examination of the issue, providing extensive case examples, and argues that deliverance is "a profitmaking frenzy organized in response to parents' concerns." He reports, "We have not come across a single church in which exorcisms and/or healing for witchcraft is free." Thus we inquired whether the families of children suspected of witchcraft are asked to make a donation/payment to the church or pastor for the deliverance. The following table includes only the 568 respondents who report that their own church practices deliverance of child witches.

Table 3.4 Material Contribution

\begin{tabular}{|c|c|c|c|}
\hline \multicolumn{2}{|c|}{$\begin{array}{l}\text { Families of suspected children } \\
\text { are asked to contribute }\end{array}$} & \multirow{2}{*}{$\begin{array}{c}\text { Frequency } \\
244\end{array}$} & \multirow{2}{*}{$\frac{\text { Percent }}{43.0 \%}$} \\
\hline Material & Never & & \\
\hline Goods to the & Sometimes & 218 & $38.4 \%$ \\
\hline Church or & Often & 69 & $12.1 \%$ \\
\hline Pastor & Always & 37 & $6.5 \%$ \\
\hline \multirow{4}{*}{$\begin{array}{l}\text { Money to the } \\
\text { Church or } \\
\text { Pastor }\end{array}$} & Never & 229 & $40.3 \%$ \\
\hline & Sometimes & 201 & $35.4 \%$ \\
\hline & Often & 88 & $15.5 \%$ \\
\hline & Always & 50 & $8.8 \%$ \\
\hline
\end{tabular}

Sixty-five percent of respondents in churches practicing child witch deliverance report that either

\footnotetext{
${ }^{66}$ Analysis of variance (ANOVA) indicates that denominational traditions differed significantly on attributes of the Child Protection Paradigm $[\mathrm{F}(3,699)=16.43, \mathrm{p}<.001]$. A post hoc Tukey test showed that Catholic churches differed from churches in the other three traditions at $\mathrm{p}<.001$, and that Protestant churches differed from AIC ones at $\mathrm{p}<.05$. The effect size was medium $\left[\eta^{2}=.066\right]$. After controlling for sex, age, educational level completed, and church size, church tradition still had a significant and medium effect on patterns related to the Child Protection Paradigm [F $=14.56, \mathrm{p}<.001, \eta_{\mathrm{p}-.060]}^{2}$.

${ }^{67}$ Revival churches fell in between Protestant and AIC churches, but were not sufficiently different statistically from either one for the difference to be statistically significant.

${ }^{68}$ Analysis of variance (ANOVA) indicates that pastoral education had a small but significant effect on child protection paradigm [F(2, $710)=6.266, \mathrm{p}<.01]$. A post hoc Tukey test showed that churches whose pastors had a four year theological diploma or above, differed from churches whose pastors were training only in ministry at $\mathrm{p}<.01$ and from pastors with only a 2 or 3 year Bible institute education at $\mathrm{p}<.05$. The effect size was small $\left[\eta^{2}=.017\right]$. After controlling for sex, age, denominational tradition, and church size, pastoral training was still positively associated with the embrace of the child protection paradigm $\left[\mathrm{F}=5.26, \mathrm{p}<.01, \eta_{\mathrm{p}-.}^{2} .015\right]$
}

${ }^{69}$ The relation between the two scales is $\mathrm{r}=-.025, \mathrm{p}=.511$. 
money or other material goods, or both, are asked of the family at least sometimes in order for the church to carry out a deliverance. Given Molina's assertion that $100 \%$ of the time such payment is expected, the fact that $35 \%$ deny that such contributions are ever requested poses its own issues. Molina reports that sometimes church leaders denied that requests for material support were occurring, but that the children's parents always reported that this had occurred. Perhaps some survey respondents who deny that such payment is requested are simply not as close to deliverance practices and thus are simply unaware that such requests are occurring. Or perhaps some are inclined to deny a potentially discrediting motivation for carrying out such practices. But if we accept the answers given, then perhaps deliverances in a minority of churches occur without any explicit request for material support. More research on this is needed.

The above two questions measure the extent to which material compensation is expected, and statistically, the two questions can be added together to form a single measure, a scale ${ }^{70}$ of "expected material compensation." There were no statistically significant differences between denominational traditions on this variable.

However, the "expected material compensation scale" was rather strongly associated with the "traditional deliverance practices scale." That is, ministries focused on deliverance using fasting, purgatives, shaving, and other traditional practices were apparently also more likely to be demanding compensation.

\subsection{What Respondents and Church Members Believe About Witchcraft}

To what extent do pastors and church members believe that some people truly cause the misfortunes of other people by means of preternatural witchcraft power? This is not an easy question to research. The Pew Charitable Trusts $(2010,178)$ surveyed Christians in 16 African countries and asked, "Do you believe in witchcraft?" Results varied by country, with an average of $42 \%$ of Christians in each country answering "yes," and $63 \%$ of Christians in the Democratic Republic of the Congo answering "yes." But the question is ambiguous. For Christians the biblical phrase "believe in" often has the overtones of "trusting in," rather than the overtones of "affirming a belief that something is true.” And as Adam Ashforth (2005) points out in his own work, many people who have profound anxieties about being the object of a witchcraft attack nonetheless think that if they refuse to "believe in" witchcraft, this refusal itself will ensure their safety. Evidence of weaknesses with the wording of Pew's question can be seen when a different question is asked. Dr. Opoku Onyinah $(2012,174)$, in a survey of 1200 Ghanaian Christians, asked: "Is witchcraft real?" With this as the question, $92 \%$ of respondents said yes-a much higher number than the $51 \%$ of Ghanaian Christians who told Pew that they "believe in witchcraft." But while Onyinah's question wording, in certain respects, is an improvement over Pew's, ambiguities remain. Neither question specifies precisely what is meant by witchcraft. Consider the ambiguities of asking "Is Hinduism real?" Is one asking whether respondents agree with cognitive assumptions associated with Hinduism, such as the supposed reality of reincarnation? Or is one merely asking whether Hinduism has a consequential social and cultural existence? Similarly, "Is witchcraft real?" can be understood either as a question about whether misfortunes may legitimately be attributed to third parties acting through evil occult means, or as a question about whether, in the modern world, there is a continuing pervasive and consequential social and cultural presence of beliefs and practices associated witchcraft.

Our survey asked respondents about their agreement with the assertion: "Certain people are truly capable of killing other people in a supernatural manner through witchcraft." The wording of this question thus intentionally stipulated the specific understanding of witchcraft belief we were asking about. And, rather than frame the matter as a simple yes or no question, as was done in Pew and Onyinah's research, we provided response options allowing for various degrees of confidence or uncertainty.

\section{Table 3.5a Belief in Witches' Power}

\begin{tabular}{lcr}
\hline $\begin{array}{l}\text { Certain people are truly } \\
\text { capable of killing other } \\
\text { people in a supernatural } \\
\text { manner through witchcraft. }\end{array}$ & Frequency & Percent \\
\hline \multicolumn{1}{l}{ Definitely Not } & 28 & \\
Probably Not & 40 & $5.9 \%$ \\
I Do Not Know & 128 & $18.0 \%$ \\
Probably Yes & 263 & $36.9 \%$ \\
Definitely Yes & 254 & $35.6 \%$ \\
\hline
\end{tabular}

Framed in this way, $73 \%$ of respondents express some level of agreement with the assertion, although with only slightly over a third (36\%) expressing complete confidence in the assertion. Nearly $10 \%$ express some level of disagreement, and $18 \%$ claim not

\footnotetext{
${ }^{70}$ With a Cronbach's Reliability Alpha of .850. With "never" counted as “(0," and "always” as "3," the scale measures churches from a minimum of "( $)$ " to a maximum of " 6 ."

${ }^{71} \mathrm{r}=.460, \mathrm{p}<.001$
} 
to know. But even those inclined to doubt the assertion are mostly tentative in their doubts, with less than $4 \%$ expressing confident denial of the witchcraft logic of power and evil.

Denominational tradition had a medium-small but significant effect on the extent to which pastors believed in the harm-causing efficacy of witch power. Specifically, Revival pastors scored higher on this belief than pastors in the other three church traditions. ${ }^{72}$ Catholic, Protestant, and AIC pastors did not differ significantly from each other.

Pastoral training had a small but significant effect on the extent to which pastors affirmed belief in the efficacy of witchcraft. Specifically, respondents whose only pastoral training was received in ministry were more likely to affirm this than those with advanced formal theological education. ${ }^{73}$

A possible behavioral indicator of the belief in witch-causing harm is the presence of people praying that God would protect them from witchcraft. Rather than ask respondents whether they themselves prayed for such protection, ${ }^{74}$ we asked whether members of their church did so.
Table 3.5b Prayer for God's Protection from Witchcraft

\begin{tabular}{|c|c|c|c|}
\hline & & Frequency & Percent \\
\hline People in My Church & Never & 145 & $20.3 \%$ \\
\hline Pray that God will & Sometimes & 299 & $41.9 \%$ \\
\hline Protect them from & Often & 182 & $25.5 \%$ \\
\hline Witchcraft & Always & 87 & $12.2 \%$ \\
\hline
\end{tabular}

Eighty percent of respondents report that such prayers occur in their church, with varying levels of frequency. Denominational tradition had a mediumsmall and significant effect on the extent to which church members pray for God's protection from witchcraft. Specifically, Revival churches scored higher on this than Protestant and Catholic churches. ${ }^{75}$ Revival and AIC churches did not differ significantly. Nor did Catholic and Protestant. On both measures above, Revival churches show elevated levels of belief and concern about the presence and power of witches to cause harm. Churches tending toward Pentecostal doctrine are also slightly but significantly more likely to pray for God's protection from witches. ${ }^{76}$

\subsection{Beliefs About the Guilt of Alleged Child-Witches}

Finally, we wished to know the extent to which pastors are inclined to believe that the children alleged to have harmed others through witchcraft are truly guilty as charged. Thus we asked, "When you think of

\footnotetext{
${ }^{72}$ Analysis of variance (ANOVA) indicates that denominational tradition had a significant effect on belief in witches' power [F(3, 699) $=13.03, \mathrm{p}<.001]$. A post hoc Tukey test showed that Revival pastors differed from Protestant pastors at $\mathrm{p}<.001$, from Catholic pastors at $\mathrm{p}<.01$, and from AIC pastors at $\mathrm{p}<.05$. The effect size was medium $\left[\eta^{2}=.053\right]$. After controlling for sex, age, educational level completed, and church size, church tradition still had a significant effect on patterns related to the pastoral belief in witches' power to harm $\left[\mathrm{F}=11.19\right.$, p<.001, $\left.\eta_{\mathrm{p}-\mathrm{O}}^{2} .047\right]$
}

${ }^{73}$ Analysis of variance (ANOVA) indicates that pastoral training significantly impacted belief in witches' power to harm $[\mathrm{F}(2,710)=$ 12.41, p <.001]. A post hoc Tukey test showed that those whose only training was in the church ministry context were more likely than those with Bible Institute training or with more advanced formal theological education to affirm confidence in such power, each at $\mathrm{p}<.001$. Effect size was small $\left[\eta^{2}=.034\right]$. After controlling for sex, age, denominational tradition, and church size, pastoral education still had a significant effect on pastoral belief in witches' power to harm $\left[\mathrm{F}=4.321, \mathrm{p}<.05, \eta_{\mathrm{p}-.012]}^{2}\right.$.

${ }^{71}$ In retrospect it would have been good to include this question also. To illustrate, on March 7 of 2013, I (Robert Priest) surveyed a small group of 23 African theologians, graduate students of theology, and denominational leaders gathered in Nairobi from across the African continent (and from the USA), and asked "How often do you pray for God to protect you from witches?" Only $13 \%$ percent answered "never," with $26.4 \%$ answering "often." The remainder indicated that they do pray for such protection, but not often.

${ }^{75}$ Analysis of variance (ANOVA) indicates that denominational traditions significantly impacted prayer for protection from witches $[\mathrm{F}(3,699)=9.67, \mathrm{p}<.001]$. A post hoc Tukey test showed that Revival churches differed from Protestant churches at $\mathrm{p}<.001$, and from Catholic churches at $\mathrm{p}<.05$. The effect size was medium-small $\left[\eta^{2}=.040\right]$. After controlling for sex, age, educational level completed, and church size, church tradition still had a significant effect on the amount of prayer for God's protection from witches $\left[\mathrm{F}=9.20, \mathrm{p}<.001, \eta^{2}-.039\right]$

${ }^{76}$ Analysis of variance (ANOVA) indicates that Pentecostal doctrine significantly impacted prayer for protection from witches [F $(1$, $711)=9.67, \mathrm{p}<.001]$. The effect size was small $\left[\eta^{2}=.028\right]$. After controlling for sex, age, educational level completed, and church size, Pentecostal theology still had a significant effect on the amount of prayer for God's protection from witches $\left[F=14.45, p<.001, \eta_{p-}^{2}\right.$ .020] 
children that you personally know who have been accused of harming others through witchcraft, which of the following best represents your point of view?"

\begin{tabular}{|c|c|c|}
\hline & Frequency & Percent \\
\hline $\begin{array}{l}\text { I think none of the accused } \\
\text { children were guilty. }\end{array}$ & 97 & $13.6 \%$ \\
\hline $\begin{array}{l}\text { I think only some of the } \\
\text { accused children were } \\
\text { guilty. }\end{array}$ & 357 & $50.1 \%$ \\
\hline $\begin{array}{l}\text { I think most of the accused } \\
\text { children were guilty. }\end{array}$ & 227 & $31.8 \%$ \\
\hline $\begin{array}{l}\text { I think all of the accused } \\
\text { children were guilty. }\end{array}$ & 32 & $4.5 \%$ \\
\hline
\end{tabular}

More than six out of every seven pastors believe that at least some of the accused children are truly guilty of having harmed others through witchcraft-although there are significant differences in their propensity to treat any given child alleged to be a witch as truly guilty. Only $4.5 \%$ believe all accused children are guilty, but with another $32 \%$ believing most accused children are guilty, and another $50 \%$ that at least some are guilty. By contrast, only $13.6 \%$ believe that all accused children are innocent of the charge that they harmed others through witchcraft.

Theological education had a small but significant effect on pastors' inclination to believe in the guilt of accused children. Specifically, pastors with formal advanced theological education were less likely to endorse accusations than were pastors whose only training was informal in the context of church ministry. ${ }^{77}$
The Constitution of the Democratic Republic of the Congo ${ }^{78}$ prohibits as "punishable by law" any accusation that a child is guilty of witchcraft. And $78.4 \%$ of our respondents indicated that they were aware that DRC law "forbids anyone to accuse children of witchcraft." The dilemma, of course, is that people who truly do believe that children sometimes cause misfortune in the lives of others by means of witchcraft, confront a law that forbids them to assert what they believe to be true.

Denominational tradition had a small but significant effect on whether or not pastors were aware of this law, with AIC respondents less likely to be aware of this law than others, and with Protestant respondents also more likely to be aware of the law than Revival respondents. ${ }^{80}$ Other differences between denominational traditions were not significant.

Awareness of the law had a significant but small negative association with the belief that children are truly guilty. ${ }^{81}$ That is, those who were aware of the law were less inclined to believe (or to report believing) that suspected children were guilty.

Since the Congolese government forbids people from accusing children of witchcraft, we naturally asked if it was forbidden in respondents' churches "to accuse children of witchcraft." Eighteen percent answered that it was always forbidden in their church, $24 \%$ that it was "never" forbidden, and equal numbers (in each case $29 \%$ ) reporting it was "sometimes" or "often" forbidden. Awareness of the above law had a significant and medium association with churches' own likelihood of "forbidding" such child-witch accusations. ${ }^{82}$ The presence and awareness of this law, publicized and

\footnotetext{
"Analysis of variance (ANOVA) indicates that pastoral training had a significant effect on tendency to believe child witch allegations $[\mathrm{F}(2,710)=5.29, \mathrm{p}<.01]$. A post hoc Tukey test showed that those with more advanced formal theological education differed from those whose only training was in congregational ministry settings at $\mathrm{p}<.01$. The effect size was small $\left[\eta^{2}=.015\right]$. Those with 2-3 years of Bible Institute training did not differ statistically from the other two groups. After controlling for sex, age, denominational tradition, and church size, pastoral training still had a significant small effect on belief in the guilt of alleged child witches $\left[\mathrm{F}=4.09\right.$, $\mathrm{p}<.05, \eta_{\mathrm{p}-}^{2}$ .012]
}

${ }^{78}$ See article 41 of the DRC Constitution (2005).

${ }^{79}$ This ranges from $87 \%$ of Protestant pastors, to $81 \%$ of Catholic, $76 \%$ of Revival, and only $58 \%$ of AIC.

${ }^{80}$ Analysis of variance (ANOVA) indicates that denominational tradition had a significant impact on awareness of this law [F(3, 699) $=7.442, \mathrm{p}<.001]$. A post hoc Tukey test showed that AIC respondents differed from Protestant ones at $\mathrm{p}<.001$, and from Revival and Catholic respondents at $\mathrm{p}<.05$. Protestant respondents also differed from Revival respondents at $\mathrm{p}<.05$. The effect size was small $\left[\eta^{2}=.031\right]$. After controlling for sex, age, educational level completed, and church size, church tradition still had a significant effect on awareness of the law $\left[\mathrm{F}=5.99, \mathrm{p}<.001, \eta_{\mathrm{p}-.020]}^{2}\right.$.

${ }^{81}$ Analysis of variance (ANOVA) indicates this $[\mathrm{F}(1,712)=10.19, \mathrm{p}<.01]$. The effect size was small $\left[\eta^{2}=.014\right]$. After controlling for sex, age, educational level completed, and church size, awareness of the law still had a significant association with likelihood of believing accusations $\left[\mathrm{F}=9.28, \mathrm{p}<.01, \eta^{2}-.013\right]$.

${ }^{82}$ Analysis of variance (ANOVA) indicates that knowledge of this law forbidding child-witch accusations had a significant and medium impact on churches' own act of forbidding child-witch accusations $[\mathrm{F}(1,711)=60.99, \mathrm{p}<.001]$. The effect size was medium $\left[\eta^{2}=.079\right]$. After controlling for sex, age, educational level completed, church size, and denominational tradition, knowledge of the law still had a significant and medium effect on church prohibitions of child-witch accusations $\left[\mathrm{F}=57.61, \mathrm{p}<.001, \eta_{\mathrm{p}-077]}^{2}\right.$ 
appealed to by the pastoral educators of EPED, appears to contribute to pastoral willingness to prohibit such accusations in their own churches.

Finally, the confidence with which respondents affirmed or questioned whether some people truly have the power to kill others through witchcraft was positively but weakly correlated with their tendency to suspect accused children of being guilty. ${ }^{83}$ The weakness of the relationship between the two is counterintuitive. In part, this reflects the fact that nearly all respondents are at least somewhat open to the possibility that witch power exists. And yet, pastors vary significantly in their tendencies either to endorse or reject the child-witch accusations they encounter. The weakness of the relationship between the two variables is a puzzle. Pastor's level of confidence or doubt with reference to witch power does not appear to be the principal variable explaining pastors' quite divergent tendencies either to endorse or reject child-witch accusations. We will return to this theme below.

\section{Chapter 4: Discussion and Conclusion}

\subsection{Christian Pastors as Central Actors in the Drama of Child-Witchcraft}

In an earlier era, anthropologists and comparative religionists assumed that belief in witchcraft would decline under the impact of modernity, urbanization, and Christianity. ${ }^{84}$ Influenced perhaps by this assumption, anthropologists largely stopped researching African witchcraft after the 1960s (Cimpric 2010, 9). But more recently, beginning in the 1990s and into the present, both anthropologists ${ }^{85}$ and African theologians ${ }^{86}$ have come to recognize that reformulated beliefs about witchcraft are proliferating and flourishing under the influence of modernity, capitalism, urbanization, and Christianity. The topic is again receiving prioritized scholarly attention. And central to the new and emerging cultural patterns is the identification of children as the locus of witch agency and harm.

Scholars who've studied the phenomenon of childwitch accusations uniformly point to the role of Christian churches in the new patterns. ${ }^{87}$ And while those who write on the topic often identify pastoral leaders of "Pentecostal churches," or "Revival Churches," or "African Independent Churches" as the central actors in the drama of child-witchcraft, our own research results in Kinshasa indicate that the relevant patterns currently exist in each church tradition. Indeed, there are greater differences between pastors and churches within each tradition than there are differences between the averages of each church tradition. On the questions we explore, all of the significant differences that do exist between denominational traditions and between those who do or do not identify as "pentecostal" are small to medium, not large.

But within each denominational tradition, one finds significant variability. In each church tradition, one finds pastors and churches that endorse virtually every child-witch accusation they encounter, and others that refuse to endorse any child-witch accusations. In some churches sermons, prayers, deliverance practices, and confessions pedagogically transmit the view that misfortunes are to be understood as caused by childwitches. In other churches, each of these is absent or at least contested. In some churches, there are ministries that prioritize practical care and protection for the accused, including defense against the very accusation itself, and in others there are ministries that portray the accused child as incredibly powerful and evil, requiring strong and even harsh interventions.

Given these divergences, it would be natural to assume that pastors simply differ in whether or not they believe in the possibility of some people having a preternatural ability to harm other people through witchcraft, and that this is what determines their tendencies either to reject or endorse child-witch accusations. But field experience, as well as the

${ }^{83} \mathrm{r}=.139, \mathrm{p}<.001$.

${ }^{81}$ For example, Geoffrey Parrinder predicted in 1958 (202-203) that "enlightened religion, education, medicine and better social and racial conditions will help to dispel witchcraft beliefs."

${ }^{85}$ See, for example, Comaroff and Comaroff 1993, 1999; Ashforth 2005; De Boeck 2013; De Boeck and Plissart 2004; Geschiere 1997, 2013; Meyer 1992, 1999; La Fontaine 2009.

${ }^{86}$ See, for example, Onyinah 2004, 2012; Asamoah-Gyadu 2015; Kunhiyop 2002; Onongha 2017.

${ }^{87}$ Adinkrah 2011; Ballet, Lallau \& Dumbi 2019; Barker 2016; Bastian 2001; Cahn 2006; Chilimampunga and Thindwa 2012; Cimpric 2010; De Boeck 2004, 2005, 2006, 2009; De Boeck and Honwa 2005; De Boeck and Plissart 2003, 2004; D’Haeyer 2004; Foxcraft 2007; Hanson and Ruggiero 2013; La Fontaine 2009, 2012; Molina 2005; Nwadinobi 2008; Onuzulike 2013; Pereira 2011; Phiri 2009; Pirot 2004; Pull 2009; Riedel 2012; Snow 2017; Stobart 2006; Tabu 2008; Tate and Stauss 2006; Tonda 2008; Van der Meer 2013; Yengo 2008. 
quantitative survey data already mentioned above, suggest this is incorrect. Consider the following two episodes.

At a 2015 workshop hosted by EPED, a Congolese theologian for three days told story after story deconstructing child-witch accusations to the great entertainment and appreciation of all. But finally, he was asked to confirm that he did recognize that witchcraft is real and that some people really are witches who harm others through their powers. He responded that while humans can use natural powers to harm others, he did not believe any human being had the supernatural ability to harm another through witchcraft. The outcry was immediate, with one pastor publicly saying, "I am so sorry you said this. We have been loving everything you have taught us for three days. It has been so helpful. But now we have to question everything you have told us." ${ }^{\text {" }}$ Privately that evening, in my (Robert Priest) presence, another church leader advised this theologian that in future he should recognize that he will lose credibility if he publicly affirms such a view.

Again in May of 2017, I (Robert Priest) spent a month with EPED pastors, listening to story after story of pastors recounting how they had defended children against witch accusations. But when some EPED leaders perceived that I thought this meant that they completely disbelieved in the reality and power of actual witches to cause harm through their supernatural powers, they treated me to a late-night banquet where they recounted personal experiences intended to convince me of the reality of witchcraft, including stories of Americans who learned to their detriment that witchcraft was real. Notably, these stories featured only adults as witches.

As our survey confirms, very few Kinshasa pastors are inclined to categorically deny the very possibility of witch causality. To do so before a Congolese audience would be to lose credibility. It would signal unbelief in the supernatural realities widely understood to be taught in Scripture. It would imply capitulation to white secularist unbelief.

Although we have no comparative data allowing us to statistically compare witch beliefs of Kinshasa residents in general with those of pastors examined in this report, it seems likely that there is marked convergence in belief. That is, it is likely that pastors are affirming, as De Boeck argued, ideas about witches that are widely shared by parents and others. But unlike the average Kinshasa resident, pastors are thought of as cognitive authorities on the realm of the supernatural. And those pastors who do claim such authority in a religious market have a competitive advantage in certain respects over those who ignore or deny what is commonly believed. In such an open religious market, churches and pastors of all traditions entrepreneurially adapt ideas and practices from those in other traditions who seem most successful in appealing to a broad audience and to its taken-for-granted assumptions. Thus the patterns examined in this paper have a strong, though not uniform, presence in each church tradition.

\subsection{Grassroots Strategies of Transformative Engagement}

How then do pastors, most of whom do believe in the possibility that some humans truly are witches causing great harm to others, nonetheless mobilize a movement to protect children from child-witch accusations and their consequences? While this research failed to focus data collection on this question to the extent it should have, a number of patterns were observed that are suggestive.

First, EPED staff reframe each claim that a child is a witch, as an allegation to be questioned, not a pronouncement to be endorsed. While others routinely refer to accused children as "witches," in the EPED workshop Robert Priest and Timothy Stabell attended leaders consistently referred rather to "children that are said to be witches." This seemingly minor linguistic shift from "child-witches" to "children that are said to be witches," laid a critical foundation for considering the many possible reasons why such claims might justifiably be questioned. When Pastor Kokasi, who attended several EPED workshops, was asked how the training changed his approach, he explained that today when parents bring their children to him and "confirm that their child is truly a witch," I no longer immediately "agree with their accusations," or "jump to a conclusion" that the child really is a witch.

Second, EPED staff encourage pastors to focus on family dynamics, especially in relation to whoever is most centrally behind the accusations. Pastors learn that a high proportion of accused children are accused by someone other than a biological parent and that when step-parents or more distant relatives are the prime accusers, there are often good reasons to distrust the accusers. EPED pastors tell story after story of the rather straightforward human dynamics discovered to lie behind allegations. Pastor Kokasi, for example, tells about a child whose mother accused him of witchcraft. Because of his EPED training, Pastor Kokasi probed further into the family dynamics and discovered that the accuser was a step-mother wishing to get rid of a child not her own. He concluded that her motives raised questions about the credibility of her accusation.

${ }^{88}$ This is an approximation of what was said, based on memory, and is not verbatim. 
The following provides a summary of case notes on a case being followed up by EPED staff during my (Robert Priest's) Kinshasa visit in May of 2017. It illustrates this strategy of engagement and also hints at others.

\section{Berthe's Story}

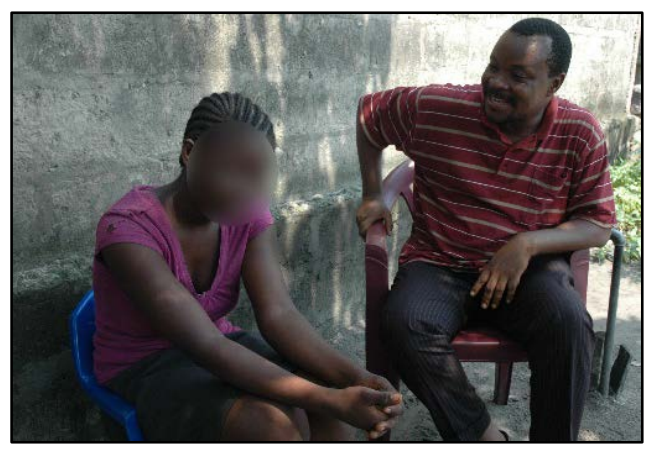

Pastor Faustin Tshiebue, of EPED, pays 17-year-old Berthe ${ }^{89}$ a visit (May 2017).

Berthe was born to an unwed mother who subsequently married. Facing financial troubles, they moved in with her maternal aunt. Her aunt saw that Berthe wet her bed, would talk in her sleep, and had poor health, and suspected Berthe was a witch that had caused her parents' financial difficulties. She took Berthe first to a prophetess, and later to an intercessor from her church, who each endorsed the charge of witchcraft. Berthe denied the allegation but was subjected to insults, threats, torture, and food deprivation (forced fasting as part of deliverance). Her aunt, not satisfied with the results, kicked Berthe out of her home. A pastor's wife learned of her situation and arranged for an EPED pastor to begin a discussion with Berthe and her mother, and with her accusers-that is, her uncle and aunt. The pastor was able to uncover and communicate the information that Berthe's stepfather had lost his job, not due to witchcraft, but because of "his poor attitude in service and his disobedience to his supervisor's instructions." The pastor stressed the value and importance of this child in the eyes of God. He explained the "law concerning child protection" and warned of possible consequences over the eviction of a child. As a result of the pastor's persuasion "there was reconciliation and a good atmosphere regained surrounding the child and all members of the family." Berthe's mother received limited financial support from EPED enabling her to start a microbusiness to provide for her daughter.
Berthe is back in school, her health restored. EPED continues to follow up with periodic visits, offering mentoring sessions with the word of God. "To this day a positive atmosphere continues to prosper within the family, and the child is doing great."

A third emphasis, as seen in the above account, is that EPED pastors continually name the harms that result from identifying children as witches, the "insults, threats, torture, food deprivation" and eviction to the streets. They work to transform the narrative of evil from a narrative that attributes great evil to accused children and point instead to the great evil perpetrated against children by their accusers. In that context, they actively appeal to (and even threaten with) the Congolese law on child protection, a law that names child-witch accusations a prosecutable crime.

A fourth aspect of EPED workshops and mentoring is the effort to critique and neutralize the logic of suspicion that deliverance ministries propagate and build their ministries on. That is, as was seen above, deliverance pastors list and identify all sorts of seemingly puzzling phenomena that are in fact common in every human community (talking in one's sleep, dreaming of flying), or phenomena that are common among those who have suffered traumas (nightmares, depression), and they coach people to believe that each of these is a symptom indicating that someone is a witch. Speakers at EPED workshops, by contrast, tell story after story pointing to alternative understandings of the very phenomena supposedly indicating a witch identity. Two of the most common dreams all over the world are dreams of flying or of being naked. But in most cultures, no one draws the conclusion that the dreamer must be a witch. Speakers remind listeners of the traumas children have experienced (such as the death of parents). They explain and elucidate the symptoms of PTSD. The very symptoms deliverance ministers list as evidence the child is the cause of great evil, they redefine as evidence the child has suffered great evil. And the stories EPED spokespersons repeatedly tell feature positive outcomes when children are embraced, cared for, fed, medically treated, counseled, educated, mentored. This is illustrated in the conclusion of EPED's report on Berthe: "To this day a positive atmosphere continues to prosper within the family, and the child is doing great!"

A fifth dimension of EPED interventions is the recognition that accusations often emerge from homes suffering economic hardship. Thus, they emphasize the importance of a holistic engagement with all dimensions of individual and family well-being, ranging from educational to medical to dietary. This is

${ }^{89}$ This name is a pseudonym. 
illustrated in the above case where EPED arranged finances to help Berthe's mother begin a small microenterprise.

Stressing the identity of the accused as children is also central to EPED's strategic response. Children are, of course, not the only ones accused of witchcraft. ${ }^{90}$ But the negative social consequences to children of such accusations are obvious, and it is doubtless easier to make a plausible and compelling appeal to the innocence and victimhood of children, than to the elderly. As alluded to in the above case notes, EPED pastors often exposit the many biblical passages showing God's love for orphans and other children, and the biblical commands for us to love and protect such children. Workshops focus on what it means practically to love children, to listen to them, to talk to them, to treat them with gentle and firm care. This focus on children represents a strategic emphasis, which potentially could be leveraged into a wider concern for other accused vulnerable parties. ${ }^{91}$

\section{Child Reintegrated into her Family}

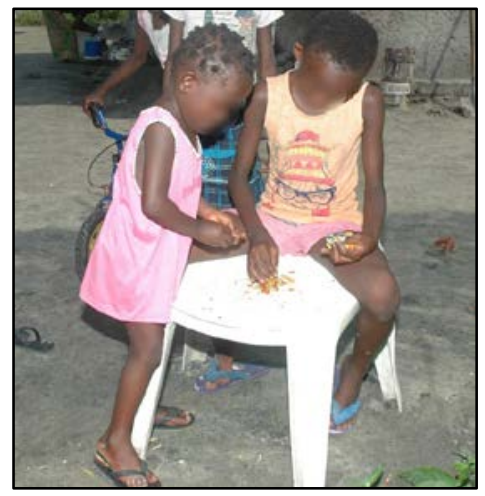

$\mathrm{Naomi}^{92}$, reintegrated into her family, plays with her little sister at EPED staff visit.

EPED leaders recount stories of how pastors or parents went through a paradigm shift, a repentance even for the way they have treated children. Parents whose kids are already on the street are encouraged to repent and go find their children, bring them home, be reconciled to them, and develop healthy ways of relating to them as children.

EPED leaders coach pastors to avoid any actions that could be interpreted as endorsing the witch accusation. One pastor reported that someone brought him a child and asked him to pray for the child. Although he had no particular reason to believe the child was a witch, he laid hands on the child and prayed. Later he was surprised to learn the relatives were telling others he had agreed the child was a witch, citing his authority on behalf of their accusations. Pastors, EPED leaders warn, must take care not to be co-opted. One EPED leader illustrated his own response to a request for prayer. A woman brought him her stepson, asking for prayer. Noticing the child's obvious health problems, and perceiving her unspoken assumption that the child was a witch, the pastor told her, before I pray I want you to take the child to a nearby clinic for medical diagnosis. He gave her money and asked that she bring him the receipt and medical report. When she returned with prescriptions, he again sent her with money to fill the prescriptions and to return with receipts. Again, he deferred prayer, telling her to go home and care for her son following the medical prescriptions. She was to return in two weeks to begin counseling and prayer. After two weeks, she returned with her son's condition greatly improved, open for him to interview them each separately, to give advice on practical family matters, and to pray in a context where it was clear the prayer was not endorsing witch suspicions. Some pastors quite decisively confront anyone seen as propagating witch suspicions. The pastor in the above case also reported on an incident when a distant aunt visited his home, with his family of many children. She began to make indirect allusions to sensing the presence of a child witch. He immediately proceeded forcefully to shout at her, "Out, out, out of my home. No one who spreads such suspicions is welcome here!"

Finally, EPED workshops are led by pastors, and sometimes by theologians-who draw from the perceived authority of Scripture and theology-to engage the issues. In the workshop we attended, Dr. Opoku Onyinah, a prominent Pentecostal theologian

\footnotetext{
${ }^{90}$ While our survey focused primarily on child-witch allegations, we did ask pastors how frequently they had received allegations that an adult was a witch, as well as how frequently they had received allegations that a child was a witch. The numbers were quite similar, but with slightly more adults accused than children. Unfortunately, we do not have data on the consequences to Kinshasa adults of such accusations, to match our extensive data on child-witch accusations.

${ }^{91}$ According to Levack (2006a, 154) "child witches figured prominently in the last great witch hunts in Sweden, Augsburg and Austria." Levack (154-155) believes the increased prosecution of children contributed to "a general doubt that those accused were guilty" and thus "played a significant role in the decline and end of witchcraft" in Europe. In short, by focusing on child-witch accusations, EPED may be contributing to a strategic step in moving church and society away from witch accusations altogether.
}

${ }^{92}$ This name is a pseudonym. 
and church leader, provided biblical and theological expositions critiquing all sorts of popular practices related to child-witch accusations, and drew from his extensive formal research and pastoral experience in relation to child witchcraft. He successfully talked through anthropological realities, psychological dynamics, and biblical teaching all in the context of recounting his many experiences with handling cases of children-each of whom he told us had been wrongly accused of witchcraft. He successfully critiqued the problems with popular child-deliverance ministries, defended the sorts of approach advocated by EPED, and appealed to his own spiritual authority as the leader of the largest Pentecostal church fellowship in Ghana in pronouncing such children innocent.

Most pastors influenced by EPED and by this approach to resisting child-witch accusations did not change fundamentally in whether or not they thought witches with harm-inducing witch powers might conceivably exist. ${ }^{93}$ Rather they changed in their predilections as to whether actual specific witch allegations should be trusted. The shift is illustrated by the words of one African seminarian ${ }^{94}$ who said, 'When I first heard my professor question whether those accused of witchcraft were truly guilty, I thought, "If 100 people are accused, maybe one of them is innocent!" But after attending pastoral workshops on the topic, and doing my own research where I met and worked closely with many individuals who've been accused, and hearing their stories, I now think, "If 100 people are accused, maybe one of them is guilty!" I suggest that this exemplifies the shift for many Kinshasa pastors, a shift with real consequences for how any actual allegation of witchcraft is engaged. Instead of a presumption of guilt, many such pastors presume the accusation is likely false. Instead of imagining evil as most likely residing centrally in the accused child, they now imagine evil as frequently residing in the false and motivated accusations of accusers, and in their actions harming the child. Pastors are opened to the idea that Satan does his work through false accusations, which is why Scripture names him the great accuser. ${ }^{95}$ When we accept false child-witch accusations against orphans, we are inclined to treat orphans as dangerous and evil. Thus we are motivated to do the work Satan desires, rather than what God calls us to, to love and protect orphans. ${ }^{96}$

In America's own most famous witch hunt at Salem, people began with an inclination to endorse every accusation. And so eighteen alleged witches were publicly hung, one was pressed to death, and hundreds more were jailed (the youngest jailed alleged witch was four years old). Witch accusations spiraled out of control. Motivations of accusers increasingly seemed suspect. The supposed evidences of guilt (e.g. "spectral evidence”) increasingly seemed problematic. Even confessions seemed less than trustworthy. At Salem, the accused who refused to confess were killed. Those who confessed escaped the death penalty. This is not a process likely to produce highly credible confessions. The result of all this was that New England went through a rapid and profound change in its perception of witch accusations. The shift was not that people become naturalists or atheists. ${ }^{97}$ Most citizens probably would not have denied the very possibility of witch powers. But, like the pastor above, who began by presuming the validity of virtually all witch-allegations, and who ended up doubting virtually all witchaccusations, this shift resulted in deep resistance ever again to wrongly contribute to the harm caused by endorsing false witch-accusations. And, in New England, the witch hunts ended. I suggest that a small, but increasing, number of Kinshasa pastors are making a similar and consequential shift. Similar networks of pastors in other cities of the DRC and in other countries are going through similar shifts.

\subsection{Christianity and Its Relationship to Witch Accusations}

While it is likely that Kinshasa pastors share many of the same ideas about witches as others in their community, they nonetheless serve as influential authorities and thought leaders who affirm, reformulate, and propagate the mix of ideas about witchcraft that is present in Kinshasa. While in the past, diviners, shamans, and traditional healers were the

\footnotetext{
${ }^{93}$ As noted above, a very small number of pastors took this position.

${ }^{91}$ This young man was a Sukuma from Tanzania, where he primarily had in mind old women as accused witches in his comments to me (Robert Priest). But I suggest this illustrates the shift many pastors have gone through in Kinshasa also.

${ }^{95}$ For a biblical and theological treatment of this theme by a theologian, see Girard (2001).

${ }^{96}$ See, for example, Psalm 82:3, James 1:27.

${ }^{97}$ Doubtless, for some, it did have this effect. In the long run, especially given the centrality of the Christian church (and of theologians such as Cotton Mather) to this Salem episode, this event doubtless had a profound negative impact on the credibility of Christianity for many, influencing a rejection of Christian faith.
} 
religious professionals that people trusted to understand, explain, and address witchcraft realities, today in Kinshasa Christian pastors are the authorities people frequently rely on for help. And while earlier mission churches seldom addressed the topic of witchcraft, a majority of today's churches-through public prayers and songs, through rituals of confession and deliverance, through pastoral sermons, and through the circulation of pamphlets and books written by pastors-actively propagate and instruct in a whole set of complex ideas related to witchcraft. Through such church pedagogy, people are taught that the various misfortunes they encounter in life are likely due to the witch agency of children and others. People learn that witches might not even know they are witches, but that the content of their dreams (dreams of flying, of being naked, of bathing children, of eating meat) demonstrates their identity as witches. They learn complex and multifarious ideas about how to recognize that someone is truly the witch who has caused the misfortune and tragedy that they experience. They learn that some Christian leaders truly understand such realities, and should be trusted to guide a process of child-witch deliverance.

In short, while most pastors' understandings of witchcraft in all likelihood do not differ fundamentally from the understandings of Kinshasa's population as a whole, pastors nonetheless play central authority roles in justifying, reformulating, and socially transmitting the complex of ideas related to child witchcraft. Today, when Kinshasa residents learn the ideas about witchcraft which they come to affirm and take for granted, it is often in church that they do so, in the very liturgy of the church, by the very authority of pastoral spokespersons. Such ideas come to seem, for many, a part of Christian orthodoxy. And, when scholars who've researched child witchcraft emphasize the role of churches and church networks (along with the influence of Nigerian, Ghanaian, and Congolese Christian movies and TV shows ${ }^{98}$ ) in spreading the new ideologies and ritual practices related to child-witch accusations, they are probably correct. That is, church networks appear to be central to the spread of child-witch ideologies and deliverance practices.

Indeed, if we rely on the extensive scholarly literature on child-witch accusations to infer its contours, this phenomenon is apparently not present in African Muslim communities in any way comparable to its presence in African Christian communities. To state this bluntly: It is in Christian churches, not Muslim mosques, where allegations of child-witchcraft proliferate and flourish. The anthropologist Aleksandra Cimpric $(2010,15)$ puzzles over this apparent fact. She mentions the possible relevance of doctrinal differences and argues that Islam and Christianity provided differing levels of opportunity and support for the improvisational translation and communication of their religious message, which she suggests may partially explain differences of outcome. While the untranslated Koran remained only in Arabic, Christians translated the Bible into each language and encouraged its meaning to be improvisationally exposited using indigenous languages and concepts. This created more scope for new hybridities, a topic to which we return below.

In any case, as our research confirms, African churches have been central both in propagating childwitch ideologies, and in working to resist child-witch ideologies, accusations, and deliverance practices. And, African church leaders and theologians, like the Boston ministers in America's own most famous witch hunt (in Salem), ${ }^{99}$ might well be the only actors in many African communities with sufficient cognitive authority to make a decisive difference. This report is written with such influential church leaders and theologians in view.

Indeed this Kinshasa research was inspired, conceived, and planned in the context of a larger scholarly conversation by an international community of church leaders and theological educators. In March of 2013, and again in March of 2016, theologians, church historians, missiologists, and church leaders gathered in Nairobi from across Africa and the wider world, to engage a pastoral and theological conversation about witch accusations and the church. ${ }^{100}$ Between the

\footnotetext{
${ }^{98}$ For Nollywood films on child-witches see Onuzulike 2014; Ugochukwu 2017; for Ghanaian films Meyer 2015; and for Kinshasa films Pype 2012. A grassroots illustration of the possible influence of these movies was reported to Robert Priest by Rev. Dr. Steve Rasmussen, a Pentecostal missionary among the Sukuma of Tanzania, where elderly widows were frequently identified as witches and sometimes killed. Steve told a Sukuma Pentecostal pastor that in Kinshasa people often accused children of being witches. The pastor declared, "That is terrible! Children can't be witches!" Ten years later, that very pastor mentioned an 8-year-old neighbor child and told Steve Rasmussen, "That child killed his mother." "But you told me children could not be witches," Steve objected. "Yes, but he confessed," was the reply. Rasmussen pinpointed the local influence of Nollywood movies and TV shows with their depictions of child witches, deliverance rituals, and confessions as likely influences on the emerging trend.
}

${ }^{99}$ If, for example, Increase Mather and other Boston ministers had responded decisively at a much earlier stage with their later theologically informed critique of spectral evidence, they could have stopped the atrocities instantly. They were arguably the only social actors in that setting with sufficient cognitive authority to have decisively made such a difference.

${ }^{100}$ With funding secured by Robert Priest and Dr. Tite Tienou from the Carl F. H. Henry Center for Theological Understandings of Trinity Evangelical Divinity School.

Priest, Ngolo, and Stabell, Christian Pastors and Alleged Child Witches 
consultations, a number of the key participants (Dr. Andy Anguandia-Alo, Dr. Kwabena Asamoah-Gyadu, Dr. Samuel Waje Kunhiyop, Dr. Opoku Onyinah, Dr. Robert Priest, Dr. Steve Rasmussen, Dr. Timothy Stabell) regularly contributed blog postings on this topic at the Carl F. H. Henry Center for Theological Understanding-with less frequent postings by others. ${ }^{101}$ And at each colloquium, among the speakers and workshop leaders, were denominational leaders of churches representing a combined sixteen million members spread across several African countries.

\section{Church Leaders from across Africa Gathered to Discuss Witch Accusations and the Church}

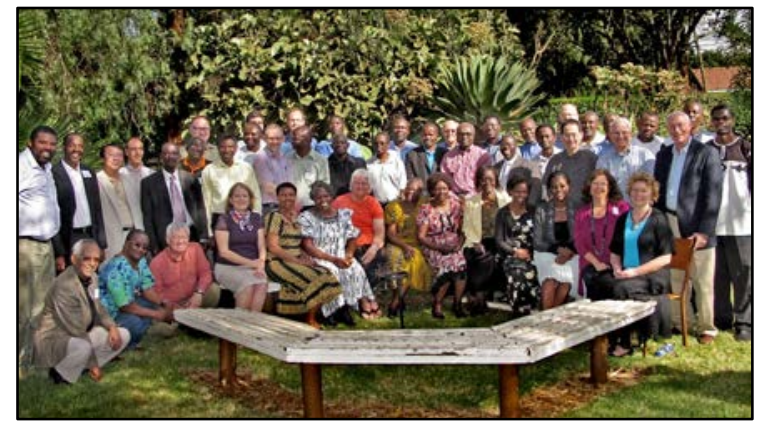

Participants at the March 6-9, 2013

Nairobi Colloquium on "Witchcraft Accusations and the Church"

From the first conference, it was clear that there was great interest in the topic. It also increasingly became clear that the conversation needed to focus, in part, on the vulnerable populations most targeted in witch accusations and violence (elderly widows, orphans, etc.), and that the role of churches in this whole phenomenon needed to be substantively considered. And while most conference participants had extensive personal experience with our topic, it became increasingly clear that high-quality research on the varying ways in which churches were understanding and engaging the issues, and with what varying outcomes, was needed as a basis for our shared conversation to move forward. Some of the most interesting conversations at the second conference focused on grass-roots initiatives with local pastors, such as when Dr. Steve Rasmussen's and several Tanzanian Pentecostal Bishops and professors described how their pastoral network went through a paradigm shift in how to engage allegations that old women were killing people through witchcraft. ${ }^{102}$ This larger conversation provided a backdrop for the desire to prioritize this Kinshasa research, research focused on a context where churches were variably engaged, and where it was possible to retain a central focus on a specific vulnerable population increasingly being targeted in witch accusations-children.

In September of 2017, several of the key participants in the above conferences (Steve Rasmussen, Abel Ngolo, Samuel Kunhiyop, Robert Priest, and Caroline Gent of The Bethany Children's Trust) were invited to speak at a workshop sponsored by the Office of the United Nations High Commissioner for Human Rights on "Witchcraft and Human Rights" that was held in Geneva. Roughly ninety scholars, activists, and human rights leaders were present. We heard stories of women burned alive as witches in New Guinea and North India, of orphan children abandoned to the streets of Kinshasa, of elderly men murdered as witches in Malindi (on the coast of Kenya), of elderly widows lynched with machetes in Tanzania, and of thousands of vulnerable women who have sought refuge from lynching in the witch camps of Northern Ghana.

\section{Speakers at Workshop Sponsored by the United Nations High Commissioner for Human Rights}

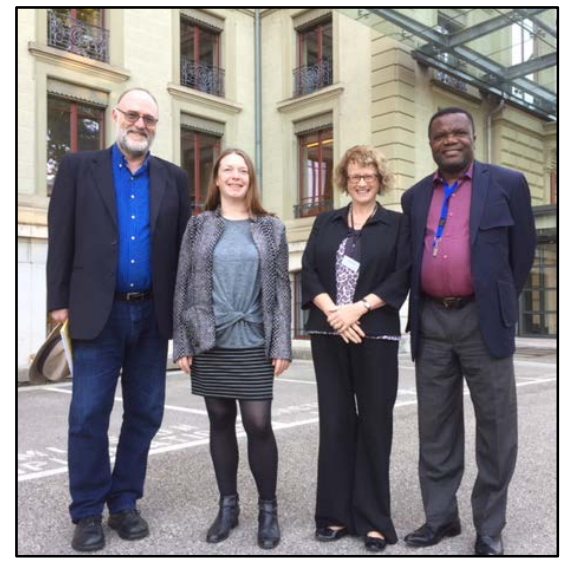

In Geneva outside the UN Palais Wilson: Robert Priest (far left), Abel Ngolo (far right), and Caroline Gent (center right).

Many of the speakers expressed a concern that witch ideologies, beliefs, and accusatory practices were all too

\footnotetext{
${ }^{101}$ https://henrycenter.tiu.edu/section/witch-accusations/. To view or download all postings in a single document, see https://www.academia.edu/40619650/Blog_Conversation_About_Witchcraft_Accusations_and_the_Church.

${ }^{102}$ Including Raphael Okeyo, Benester Misana, and Nestory Lunyilija.
} 
often propagated through Christian religious institutions and networks. That is, speakers not only reminded us that Christianity had played a historical role in helping legitimate the ideas that led to the European witch hunts, but argued that Christian communities today sometimes continue to accredit ideas that contribute to the sometimes aggressive actions directed at those alleged to be witches. However, a number of human rights activists also expressed a recognition that their own secular humanism significantly hindered them from having a credible voice with many local communities. And indeed, there was a recognition that a number of Christian faith-based initiatives, led by confessing Christians, were having a significant positive impact for good. Thus, a distinctive feature of this UN conference was the invited presence of church leaders, theologians, missionaries, and missiologists as full conversation partners-including several from our own working group.

\subsection{Where do we go from here?}

Contestable ideologies about witchcraft have permeated the discourses, liturgy, and practices of many churches with profound consequences for human lives. And when grassroots networks of pastors strive to wisely engage the issues, we should applaud. But the seriousness of the issues, and the difficulties they pose for Christians, and the implications of our engagements for the credibility and witness of Christian churches across time and space, would suggest the importance of an Africa-wide and even global Christian conversation among church historians, biblical scholars, theologians, missiologists, and anthropologists over the issues and their implications. The very topic of witchcraft naturally lends itself to such an interdisciplinary dialogue. This in-depth research on childwitchcraft in Kinshasa provides a significant starting point for further discussion and engagement of the issues. And since the on-line journal "On Knowing Humanity" exists to foster integrative dialogue between theology and anthropology, and has agreed to publish this report, as well as to publish a variety of responses by knowledgeable Christian scholars from diverse disciplines and regions of the world, this is a potentially ground-breaking publication event where a variety of contributors are invited to help us all gain clarity on the issues involved.

The following are a few selective observations for contributors to consider as we brainstorm how to move the conversation forward in a constructive way.

New Hybridities. First, we should acknowledge that Christian discourses and practices inevitably involve admixtures or hybridities of meanings, categories, assumptions, actions, and intentions indebted to some combination of Scripture and culture. This happens in every cultural setting in relation to all sorts of difficult matters ranging from sexual ethics to witchcraft. Within the rubric of orthodox Christian faith, hybrid formulations can involve either a healthy and proper contextualization of the Christian faith or alternatively a flawed and harmful syncretism. Exploring and assessing this requires 1) careful attention to the actual discourses and practices of a given Christian community and of its spokespersons, 2) careful attention to traditional discourses and practices of the prior or wider culture, 3) careful attention to what Scripture itself does or does not support, and 4) a careful effort to assess contemporary teachings and practices in the light of the first three. Considering all of this requires understandings of anthropology, of culture, of the history of the gospel/culture encounter, of the contemporary cultures of specific Christian communities, and of Scripture. The following is intended to illustrate first, what is meant by a hybrid concept, and second to point to broader themes and processes to be grappled with.

The Mystical Seed of Witchcraft. According to leading deliverance ministers in Kinshasa, a witch is a person contaminated with a "mystical witchcraft seed" that empowers them towards harm, evil, and destruction. This witchcraft seed can be transmitted into someone by means of contact with a gift of food, drinks, clothes, or toys. Alternatively it may be transmitted in a dream, through sex, or acquired from one's mother while still in the womb. The presence of this seed gives Satan total authority and control. This seed is not itself a spirit, but allows Satan to influence the witch's behavior (manifesting itself in hatred, arrogance, "exaggerated nudity," or "lack of self-control shown by untamed words, open brutality, epidermic reactions"). Through this seed Satan is also able to influence the witch's dreams, which then feature "life in places lived long ago," "abominations and aberrations," and "troubled, tormented, disruptive" dreams." Such persons become "fundamentally bad." "Like a bomb," those with the witchcraft seed are a source of "massive destruction." Witchcraft is the means by which Satan accomplishes his goal as articulated in John 10:10_"to steal, to kill, and to destroy." Witches serve their master, Satan. When the seed is fully activated, a witch moves from unconscious sorcery to conscious sorcery. The first transmission of this evil seed unleashing "all the power of destruction of the tripartite human being, i.e. body, soul and spirit" occurred in the Garden of Eden, with the eating of the forbidden fruit. Examples in Scripture of those with this mystical seed include Nabal (I Samuel 25) and Judas. Deliverance must be 
oriented towards the removal of this seed. ${ }^{103}$

There are some clear parallels here to pre-Christian ideas of a witchcraft "substance" that a diviner would sometimes remove from an alleged witch. Through the recurrent biblical metaphor of "seed" that is linked to evil, to sin, and to Satan (as in the Genesis 3:15 reference to the "seed" of the Serpent), the "substance" idea is transformed into a "seed" that remains impersonal, but is now Satanically empowered.

The Meaning of Suffering. In every society, people have struggled to make sense of misfortunes and suffering which they experience. But how they explain such afflictions varies from one culture to another. In some cultures, people explain suffering by recourse to what anthropologist Richard Shweder (2003) calls moral causal ontologies. In such cultures, when a man has painful and mysterious physical afflictions, the repeated death of children, the loss of wealth and fortune, as with Job in the Bible, cultural counselors will interpret the afflictions as a sort of karma for the sufferer's own sin. Everyone gets what they deserve, perhaps because of sins in a prior life. But in other cultures people never explain misfortune in this way. In some cultures people explain misfortune by reference to auspicious vs. inauspicious times and seasons, what Shweder calls an astrophysical causal ontology. But Shweder points out that the most common causal ontology, although not present in every society, is an interpersonal causal ontology which attributes suffering and misfortune to other human beings thought to have caused harm through evil occult power. The precise cultural theory for how the power operates varies from one culture to another. But what such cultures share is the explanation that another malevolent human being is to blame. In such cultures, every misfortune and death triggers a quest to identify some third human party to hold responsible. The "why" question is transformed into a "who" question, as in Sylvain Mbaki's family quest for "who" killed his deceased sister. And as we saw earlier, many Kinshasa pastors teach people to attribute the misfortunes in their lives to witches, including child-witches. According to Shweder, such an interpersonal causal ontology is extremely wide-spread. The Bible, of course, is also filled with narratives of suffering, infertility, and death-and addresses the meaning of suffering and affliction in a variety of ways. A more careful comparison of the most widespread ideas in Kinshasa for how to make sense of misfortune with the full spectrum of biblical teaching on the subject, is needed. Sometimes Scripture does attribute afflictions to demonic or Satanic agency, which introduces our next theme.

Satan, Demons, and Witches: Consider the matter of how to understand the Christian Satan in relationship to the witch idea. While the concept of a high God was common in many African societies prior to the presence of Christianity, the concept of a Satan figure, of a powerful and evil supernatural being as the discursive focus of evil, as the opponent of God and the good, the leader of a host of demonic beings similarly inclined, was absent. Ancestral spirits and nature spirits were often understood to exist, but were not understood as ultimate opponents of God or the good. In African traditional moral discourses, the discursive focus of evil was centered rather on the image of the human witch-the incarnation of anti-social impulseswho was thought to be envious, malicious, resentful, cannibalistic, harmful and hateful, without normal moral scruples. The witch's power was understood as personal and psychic or magical, but was not normally thought of as power derived from sentient nonhuman spirits. That is, witch power was power that belonging to the person of the witch, not to a spirit. But, as argued by Onyinah $(2004,2012)$, the advent of Christianity fostered new hybrid formulations. Since both Satan and the traditional image of the witch were central images of evil, the similarities naturally resulted in conflations of the two. Since indigenous languages lacked words that closely fit the idea of Satan, it was often words associated with witches that were used for Satan. For example, while the Adioukrou of Côte d'Ivoire traditionally had no concept of a supernatural Satan, or even of evil supernatural beings implacably opposed to God and the good, they did have a concept of a witch $(a g n u)$, whose witchcraft power (agn) was directed in anti-social and harmful attacks on others. In traditional understandings, this agn was a psychic power that belonged to the agnu (the witch) and had nothing to do with sentient non-human spirits. But under the influence of Christianity, the psychic meaning of the traditional word for witchcraft, agn, was transformed into the notion of a sentient, evil non-human being, and became the very word Christians and others used to refer to "the devil" (Hill 2007). This did not mean that the Adioukrou abandoned the idea of human witches, only that they transformed the logic for how the human witch $(a g n u)$ acquired and utilized power. People still accused other people of being agnu (a witch), of having caused their misfortunes, but now the harm was understood simultaneously as a harm produced by a person and by a sentient supernatural devil. When the Bible was later translated into Adioukrou, agn became the word used for "the devil" (Hill 2007). Similarly, the anthropologist Birgit Meyer, in her book Translating the Devil (1999a), documents how early missionaries to the Ewe of Ghana translated Satan as Abonsam, an

${ }^{103}$ Wallo Mutsenga 2013; Kigalu Mangala 2008, 87, 123, 205, 77, 84-85, 145; Kalonji 2003, 26-27. 
Akan term which she says was originally understood by the Ewe as a synonym for "witch." Every Ewe and Adioukrou Christian reference to Satan, and indeed every biblical reference to Satan in their translated Bibles, thus becomes simultaneously a reference to, and ratification of, the witch idea. But whether or not words meaning "witch" were used to translate the idea of Satan, ${ }^{104}$ the associations between the two were easily and frequently made. The very description of Satan as one who came to "steal, kill, and destroy" named Satan as doing precisely what witches were traditionally understood to do. Associating the two was quite natural. And increasingly older ideas of witches that operated with their own psychic power transitioned to newer ideas linking them to demonic power-a power to be combatted by deliverance. Onyinah $(2004,2012,2001)$ argues that these new hybrid understandings emerged among Ghanaian Christians partly indebted to ancient African understandings, partly indebted to the Scriptures as translated and communicated by missionaries, and partly inspired by the "spiritual warfare" writings of westerners (he mentions Derek Prince, Charles Kraft and Peter Wagner). This new "witch-demonology" cited passages in the gospels where Jesus cast demons out of people that were afflicted, as justification for utilizing deliverance methods on people understood to be witches. That is, they applied deliverance to people understood as the cause of other people's afflictions. This, despite the fact that none of the Gospel accounts even hints at the idea that those being delivered were suspected of having harmed others through witchcraft. Rather the Gospels associate demonized ("demon-possessed") people with those whom Jesus healed of various diseases, and thus identifies them as fellow sufferers rather than as somehow responsible for the suffering of others. Onyinah provides an excellent initial discussion of such dynamics and processes, illustrating the sorts of analysis and assessments that are needed.

Is the witch idea universal? Anthropologists report that people in a high proportion of traditional societies did explain misfortune by reference to the notion that certain antisocial persons harmed others through some form of evil occult power. The precise logic of how the power was explained was culturally variable (psychic, magical), and indeed was frequently modified under the influence of Christianity towards a more demon-based logic of power. In any case, the interpersonal causal ontology logic was quite widespread. But it was not universal. ${ }^{105}$ Robert Priest, the child of missionaries to the Bolivian Siriono, agrees with earlier anthropologists that while the Siriono believed in spirit realities (and told stories of fearsome encounters with nature spirits), they never attributed their own misfortunes to the mystical evil powers of another person. There were no witches even in the imagination of this society. This historical absence of the witch idea was not unusual for hunter-gatherer societies, or for some East Asian societies.

How exactly were the cultures different between those with the witch idea, and those without it? First, cultures with the witch idea exemplified an interpersonal causal ontology. People regularly explained infertility, sickness, poverty, and the death of loved ones by pointing to other human beings as to blame. Second, their languages had lexically specified terms for evil persons with occult powers thought to cause the misfortunes of others, words like ndoki, mchawi, mulozi, doka, maye, oleu, akut, muoi, omorogi, murogi, mthakathi, boloki, fwiti, mfiti, and suba. Third, in such cultures each misfortune or sequence of misfortunes triggered efforts to identify the supposed witch-often with a highly elaborated set of ideas about the signs that indicate one is a witch-such as red eyes, whiskers on an old woman, white hair on an old man, etc. Magico-religious professionals (shamans, diviners, prophets, pastors) publicly offered consultative services to identify and deal with the person thought to have caused the problem. In situations with high levels of misfortune, witch hunts may be conducted to ferret out witches. Fourth, it is frequently the case in such cultures that witch accusations are directed at powerless, vulnerable people-at widows, the poor, the disabled, the elderly, orphan children, and strangers. A byproduct of this is that discourses about these categories of people in these cultures will often feature negative stereotypes and will encourage antipathy and fear of those who objectively are weak and vulnerable, rather than encouraging empathetic love and concern for them. Fifth, since cultures the world over believe serial murderers should be punished, when deaths are attributed to murders through witchcraft, there is typically a strong culturally shared impulse to get rid of the accused person either by violent eviction or lynching. When witch panics and witch hunts begin, this can sometimes result in the lynching of large numbers, as apparently occurred in June and July of 2001 around the Lugbara community of Aru (in the DRC), where several hundred people were reportedly killed

\footnotetext{
${ }^{104}$ A more common Bible translation strategy was simply to use a transliteration of the name "Satan," rather than trying to find an equivalent term in the local language.

${ }^{105}$ George Peter Murdock (1980, 22-26) lists a number of traditional societies where anthropologists report that the witch/sorcerer explanation of illness was historically absent: Atayal, Aweikoma, Bororo, Bushmen, Japanese, Manchu, Samoyed, and Siriono.
} 
(unpublished research by Dr. Andy Anguandia-Alo). ${ }^{106}$ Sixth, there is strong evidence in such societies that people not only feel deep insecurity, but that they respond to this insecurity by methods thought to protect from the witch attacks of neighbors, relatives, or colleagues. Such methods may include use of protective charms and amulets, or of prayers to God for protection. All six of these patterns characterize a high proportion of traditional societies around the world, including Europe between 1450 and 1750 when fortyfive thousand Europeans were executed as witches (Levack 2006, 1-29).

But in other societies, such as with the Siriono or Koreans, all six traits are missing. How has Christian contextualization worked in such societies? To what extent does one find in these societies discourses and practices similar to those in Kinshasa churches? Such societies, especially where Christianity has become strong make interesting test cases to consider in terms of the idea of the witch. After all, doesn't the Bible itself teach the idea of the witch-the idea that some people, through evil occult power, are secretly the cause of other people's misfortunes?

This is a larger topic than can be fully addressed here. But we wish to illustrate the possibility that Christians have fundamentally misread their Bibles, and thus that a larger conversation is needed that involves the biblical text, later translations, anthropological categories, and theological reflections.

Consider then, what is perhaps the central biblical text, one that most Kinshasa pastors can quote, translated into most Congolese languages ${ }^{107}$ roughly as, "you shall not allow a witch that is a woman ${ }^{108}$ to live (Exodus 22:18).” When many African Christians read their Bibles, whether in local languages or in English or French, it will appear that the Bible itself straightforwardly affirms the common cultural belief that the real reason for people's misfortune is neighbors, relatives, or colleagues who are secret witches inflicting harm on others through evil occult power, and that the prescribed solution in Exodus, when faced with misfortune, was to seek to identify the individuals who are secretly causing misfortune to others and remove them. In cultures that already have witch ontologies, this translation will be seen as a Christian endorsement of prior cultural assumptions and dispositions. And since the powers of witches operate invisibly, then there is a need for special routes to knowledge, if one is to identify such witches. To be clear, few contemporary pastors are utilizing this passage to call for the death of supposed witches. But many Christians do understand it as providing the underlying logic of why such people are evil (they cause harm and death), and the underlying logic for why they must be identified and dealt with.

It is interesting to consider the Bible which Korean Christians read, one in which Exodus 22:18 translates the Hebrew kashaph as moodang, a female shaman. The Korean Bible, identifies this person, not as witch, but as having an identity similar to that of African diviners and traditional healers. That is, a moodang has a public identity, and seeks clients whom they can provide services to. Koreans do not attribute misfortunes to the moodang. When Koreans read their Bibles, they will understand this passage as similar to many other Old Testament passages (Lev 19:31; 20:6; Deut 18:10-12; Isa 8:19-20; Jer 27:9) that condemn a wide variety of magico-religious professionals, ranging from diviners to mediums. And since these sorts of magico-religious professionals recruit clients during life crises and interpret the ultimate meaning of their life situation, what their future holds, while also prescribing magico-religious solutions to their problems, such public professionals are religiously competitive with the meanings, spokespersons, solutions, and allegiances or relationships that God was said to approve. Thus, the people of God should not become the trusting clients of magico-religious practitioners not endorsed by God, fostering ideologies and solutions not endorsed by God, and the nation of Israel should not permit such persons to advertise, recruit, and carry out their meaningpropagating activities within its borders.

Korean Christians read a fundamentally different Bible, in this respect, than do Congolese Christians. There are no witches in the Korean Bible. And the witch idea is not salient to how mainstream Korean

\footnotetext{
${ }^{106}$ See also: Adrian Bloomfield. 2001. "Massacre in the Jungle by Witch-Hunters," News.telegraph, http://www.telegraph.co.uk/news/worldnews/africaandindianocean/democraticrepublicofcongo/1335661/Massacre-by-the-junglewitchhunters.html. [Viewed October 30, 2019]
}

\footnotetext{
${ }^{107}$ This includes, for example, Bibles in Kanioka, Kikongo, Kisonge, Kituba, Lingala, Lomongo, Ngbaka, Swahili, Tetela. For Congolese Bibles consulted, only the Tshiluba Bible avoided the Tshiluba term for witch (muloji), and used a title for an identity (muena majimbu) that is publicly claimed and performed before others, that offers to help clients counteract witchcraft.

${ }^{108}$ While this is not our focus here, it is worth pointing out the odd (and problematic) message conveyed when African witch categories (such as mchawi, muchawi, ndoki, mfiti, omorogi, murogi, muoi, fwiti) are understood locally to be either male or female-with male and female secret killers equally bad-and yet where the translated biblical texts, in an effort to be faithful to the original Hebrew grammar, implies that God only wishes the female versions of secret killers to be punished.
} 
Christians understand the supernatural world.

For Christians who accept the authority of Scripture, the question remains, what exactly is the correct interpretation of this passage? How should this passage be translated? Into what local linguistic categories? Should local terms for evil secret killers be used? Or should translators use local terms for magico-religious professionals offering their services to contact the dead, forecast people's futures, provide healing through special supernatural powers, etc.? The answer to this question is not easy. The critical Hebrew word kashaph appears only a few times in the Old Testament, usually without enough context to guess its meaning. But a number of converging lines of evidence are suggestive. Etymologically it may have come from a word meaning "to mutter" (Bretherton 2005, 147). One clue to the Hebrew meaning of kashaph is present is the way the third-century BC Septuagint translated it into Greek using the term pharmakous, a word from which we get our term "pharmaceutical" and which appears to have been associated with incantations, herbs, potions, and medicines (ibid). In short, the pharmakous translation likely implied some sort of magico-religious practitioner offering their services for pay, and actively recruiting others to become clients, rather than the ascribed category of "secret killer." Of course when the later Latin Vulgate translated Exodus 22:18 as maleficos, implying malicious harm, this more closely approximated meanings parallel to many Congolese translations, but not to the Korean one.

A second line of evidence relates to the idea that when a list of categories are presented together as a cluster, they are often of a similar sort. Thus when one notices that the Hebrew word kashaph appears in lists (such as Exodus 7:11, Deut 18:10, Daniel 2:2) with other identities that are better understood, and where all the other identities relate to publicly claimed categories of people offering their services to clients, it makes sense that kashaph would be a similar sort of category. And indeed there are only two Old Testament passages where kashaph is used with enough context to infer its meaning, a meaning similar to African categories for people who offer their services to clients (nganga, nganga-kisi, mfumu, shalubuku) rather than to the ascribed category of witch (ndoki, mchawi, muloji, mfiti, mthakathi). In Exodus 7:11, after Moses performs wonders, Pharoah calls for his guild of kashaph, to see if they can perform similar wonders. And in Daniel 2:2 King Nebachadnezzar calls for his guild of kashaph to interpret a dream. In short, in the only two instances in Scripture where we actually see the word used descriptively of an ethnographic event, kashaph is applied to magico-religious professionals employed by a king to do precisely the sorts of things that diviners, shamans, and wonder workers do for clients. These are not framed as secretly evil destroyers of human lives and human flourishing.

In a 2002 interview, Eugene Nida, the "world's most influential Bible Translator," complained in a Christianity Todayinterview that many Bible translators fixate on, and worship, words, but fail to understand that "words only have meanings in terms of the culture of which they are a part" (Nida and Neff 2002, 46). This suggests a final line of evidence involving the larger culture of which kashaph is a part. As suggested earlier, anthropology demon-strates that six cultural attributes cluster together with the cultural construct of the witch. One of those has to do with the presence of a linguistic category for witch. But since it is unclear whether or not kashaph fits the witch category, it makes sense to look at the other five aspects that normally accompany the lexical presence of a witch concept, to see whether it fits.

First, such a concept will derive its cultural meaning from a broader underlying causal ontology that is interpersonal. In short, cultural discourses about infertility, poverty, suffering, sickness, and death will continually attribute misfortunes to the occult evil agency of malevolent neighbors, relatives, or colleagues. But while such attributions are pervasive in cultures with witch constructs, and while the Bible itself is filled with narratives about infertility, poverty, suffering, sickness, and death, there is not one single example anywhere in Scripture where anybody's misfortune is ever attributed to the evil occult agency of another human person. The book of Job, for example, is one long narrative about precisely the misfortunes that in other cultures would be explainable only in terms of evil third-party witches. But the counselors of Job's culture explained misfortunes by appealing to a radically different causal ontology-a moral causal ontology. Never once do they even hint at the idea that some neighbor, relative, or colleague of Job might be causing his misfortune through witchcraft.

Second, in such cultures whenever misfortune strikes, major efforts are exerted to identify the evil witch causing the problem, with special techniques and powers and with magico-religious professionals deployed to hunt and identify those thought to have caused the misfortune of others. Again there is no evidence for any of this from Hebrew narrative.

Third, such cultures often attribute negative characteristics to orphans, widows, the poor, disabled, elderly, and strangers-who are frequently accused of being witches-and encourage a lack of empathy for them. But these are precisely the categories that the Old Testament Jews were called to love and care for, not to fear. Indeed, the Exodus 22:18 passage is immediately followed by instructions to protect and care for strangers, widows, and orphans.

Fourth, such cultures will sometimes experience witchcraft panics and witch hunts designed to ferret out 
and kill the many people presumably to blame for causing the misfortune and death of others through their anti-social hostile occult aggressions. Again, such a pattern is lacking for OT Jewish culture.

Fifth, in such cultures people seek for safety from witches through magical or religious means. But while many Christians in cultures with witchcraft ontologies regularly pray for God to protect them from witches, and while the Bible is filled with prayers, one cannot find a single instance in the Bible of a prayer for protection from witches.

In sum, in the absence of the larger cultural patterns associated with, and essential to, witch meanings, the Hebrew word kashaph is unlikely to have been understood by Jews as having similar meanings to mthakathi for the Zulu, muoi for the Kamba, ndoki for the Lingala, or mchawi for the Swahili.

In much of the world today, church leaders teach their followers to attribute their misfortunes to neighbors, relatives or colleagues understood as hostile and powerful witches. One reason they do this is because they have read their Bibles. Of course, how their Bibles were translated, and with what cultural, theological and pastoral implications, is a matter of deep import. If the above summary is correct, then the issues playing out in Kinshasa churches have contributing translational roots that go back all the way to the Latin Vulgate translation-a translation that influenced the whole history of Western Christendom. The fact that witch hunts thrived under Latin influenced Christian territories and not under Greek influenced Christian territories, raises interesting questions on the extent to which differing Bible translations affected this-with Western Europe influenced by the maleficos translation. ${ }^{109}$

As Christians, many of us will find these issues deeply painful. But we must have the courage to ask difficult questions, the energy to engage these issues through the hard work of reading, of research, of the give and take of substantive debate, and of the grace to interact with other Christians in other disciplines and from other countries, constructively and substantively. May God give us wisdom.

We close with a reminder. It is helpful for all interlocutors to keep one aspect of the experience and approach of EPED pastors in view. Some theologians and anthropologists theorize about these matters with minimal attention to the fact that alleged witches are actual people who suffer actual consequences of being named a witch-the locus and cause of affliction for others. Some anthropologists perceive witch discourses purely as symbolic, metaphoric social commentary. Some theologians perceive the issues of witchcraft purely in terms of whether or not one recognizes supernatural realities. But EPED pastors begin with the presence of a suffering child on the street, a suffering child who is there because someone accused him of having caused, for example, the death of his mother, through witchcraft. They confront the fact that an alleged witch is an actual person, and that when this person is a child, such an accusation raises profound moral, ethical, and practical questions of engagement. Furthermore, EPED pastors are also aware that the ministries of Christian pastors sometimes helped put that child on the street. And they recognize that flawed biblical and theological understandings sometimes contribute to the problem.

Our research showed that theological education made a positive difference for pastors. But perhaps not as much as it should have. Our hope is that this research report will inspire many others to generate a helpful body of writings reflecting diverse disciplines and ministry contexts that can be incorporated into the curriculum of theological schools in cultural regions where these issues are at stake.

\section{Reference List on Witchcraft}

Adinkrah, Mensah. 2011. Child witch hunts in contemporary Ghana. Child Abuse \& Neglect 35(9): 741-752.

Adu-Gyamfi, Yaw. 2016. Thou shalt not suffer a witch to live (Exod 22 18) and contemporary Akan Christian belief and practice A translational and hermeneutical problem. Old Testament Essays 29(1): 11-32.

Asamoah-Gyadu, J. K. 2015. Witchcraft accusations and Christianity in Africa. International Bulletin of Missionary Research 39 (1): 23-27.

Ashforth, Adam. 2005. Witchcraft, violence, and democracy in South Africa. University of Chicago Press.

Balibuno Zahinda Byamungu, Justin. 2013. La Guérison des maladies d'origine démoniaque. Kinshasa: Réconciliation.

Ballet, Jérôme, Benoit Lallau and Claudine Dumbi. 2019. The exploitation of Sorcerer Children in Kinshasa (RDC). In Child exploitation in the Global South, 125-140. Palgrave Macmillan, Cham.

Bar, Shaul. 2011. Saul and the Witch of En-Dor.Jewish Bible Quarterly 39(2): 99.

Barker, Eileen. 2016. An introduction to The Devil's Children. The Devil's Children: From Spirit Possession to Witchcraft: New Allegations that Affect Children. Jean La Fontaine, ed. Pp. 1-12. Ashgate Publishing Ltd.

\footnotetext{
${ }^{109}$ Steve Rasmussen first suggested I check this dynamic out, given my argument about the importance of translation history.
} 
Barry, Aboubacar. 1998. Marginalité et errance juveniles en milieu urbain. La place de l'aide psychologique dans les dispositifs de prise en charge des enfants de la rue. Psychopathologie Africaine 24 (2): 139-190.

Bartholomew, Leethen. 2015. Child abuse linked to beliefs in witchcraft. Transnational Social Review 5(2): 193-198.

Bastian, Misty L. 2001. Vulture men, campus cultist, and teenaged witches: Modern magics in Nigerian popular media, In Magical interpretations, material realities: Modernity, witchcraft and occult in postcolonial Africa. Henrietta L. Moore and Todd Sanders, eds. Pp. 71-96. New York, NY. Routledge.

Biehl, João 2013. Vita: Life in a zone of social abandonment. Berkeley: University of California Press.

Blanes, Ruy. 2017. The Ndoki Index: Sorcery, Economy, and Invisible Operations in the Angolan Urban Sphere. In Pentecostalism and Witchcraft. Knut Rio, Michelle MacCarthy and Ruy Blanes, eds. Pp. 93-114. Palgrave Macmillan, Cham.

Bohannan, Laura. 1966. Shakespeare in the bush. Natural History (August/September), 28-33.

Bosch, David. 1987. The problem of evil in Africa: a survey of African views of witchcraft and of the response of the Christian church. In Like a roaring lion: Essays on the Bible, the Church, and demonic powers. Pieter G.R. de Villiers, ed. Pp. 38-62. Pretoria: University of South Africa Publishers.

Brain, James L. 1982. Witchcraft and development. African Affairs 81 (324): 371-384.

- 1997 . An anthropological perspective on the witchcraze. In Magic witchcraft, and religion: An anthropological study of the supernatural. Arthur C. Lehmann and James E. Myers, eds. Pp. 192-198. Mountain View, CA: Mayfield Publishing Company.

Brain, Robert. 1970. Child-witches. In Witchcraft confessions and accusations. Mary Douglas, ed. Pp. 161-179. London: Tavistock Publications. [Bangwa, Cameroon.]

Bretherton, Donald J. 2005. An invitation to murder? A reinterpretation of Exodus 22:18 'You shall not suffer a witch to live.' The Expository Times 116: 145-152.

Brown, Michael. 1989. Dark side of the shaman. Natural History (November): 8-11.

Burden, Jasper J. 1973. Magic and divination in the Old Testament and their relevance for the Church in Africa. Missionalia: Southern African Journal of Mission Studies 1(3): 103-112.

Cahn, Naomi R. 2006. Poor children: Child witches and child soldiers in sub-Saharan Africa. Ohio State Journal of Criminal Law 3: 413-456.

Chilimampunga, Charles and George Thindwa. 2012. The extent and nature of witchcraft-based violence against children, women and the elderly in Malawi. Research Study Final Report, Submitted to The Royal Norwegian Embassy.

Cimpric, Aleksandra. 2010. Children accused of witchcraft: An anthropological study of contemporary practice in Africa. Dakar: UNICEF WCARO.

Cohan, John Alan. 2011. The problem of witchcraft violence in Africa. Suffolk University Law Review 44(4): 803-872.

Comaroff, Jean and John Comarroff. (eds) 1993. Modernity and its Malcontents: Ritual and power in postcolonial Africa. Chicago: University of Chicago Press.

- 1999. Occult economies and the violence of abstraction: Notes from the South African postcolony. American Ethnologist 26 (2): 279-303.

Daneel, Marthinus L. 1990. Exorcism as a means of combating wizardry: Liberation or enslavement? Missionalia 18(1): 220-247.

Danfulani, Umar Habila Dadem. 2007. Anger as a metaphor of witchcraft: The relation between magic, witchcraft, and divination among the Mupun of Nigeria. In Imagining evil: Witchcraft beliefs and accusations in contemporary Africa. Gerrie ter Haar, ed. Pp. 141-184.

De Boeck, Filip. 2004. On being Shege in Kinshasa: Children, the occult, and the street. In Reinventing order in the Congo. How people respond to state failure in Kinshasa. T. Trefon, ed. Pp. 495-505. London: Zed Books.

- 2005. The apocalyptic interlude: Revealing death in Kinshasa. African Studies Review 48(2): 11-32.

- 2005. The divine seed: Children, gift, and witchcraft in the Democratic Republic of the Congo. In Makers and breakers: Children and youth in post-colonial Africa. Filip De Boeck and Alcinda Honwana, eds. Pp. 188-204. Oxford: James Currey.

- 2006. Youth, death and the urban imagination: A case from Kinshasa. Bulletin des Séances 52 (2): 113-125.

—. 2008. 'Dead society' in a 'cemetery city': The transformation of burial rites in Kinshasa. In Heterotopia and the city: Public space in a post-civil society. Michiel Dehaene and Lieven De Cauter, eds. Pp. 297-308. New York: Routledge.

- 2009. At risk, as risk: Abandonment and care in a world of spiritual insecurity. In The Devil's children: From spirit possession to witchcraft-New allegations that affect children. Jean La Fontaine, ed. Pp. 129-150. Surrey, England: Ashgate Publishing Limited.

- 2012. Kinshasa and its (un)certainties: The polis and the sacred. In The sacred in the city. Liliana Gómez and Walter Van Herck, eds. Pp. 191-207. London: Bloomsbury.

- 2013. The sacred and the city: Modernity, religion, and the urban form in Central Africa. A Companion to the Anthropology of Religion. Pp. 528-548.

- 2015. "Poverty" and the politics of syncopation: Urban examples from Kinshasa (DR Congo). Current Anthropology 56 (S11): S146-S158. 
De Boeck, Filip and Honwana, A. 2005. Introduction: Children and youth in Africa-Agency, identity and place. In Makers and breakers: Children and youth in postcolonial Africa. A. Honwana and F. De Boeck, eds. Pp 1-18. Oxford: James Currey.

De Boeck, Filip and Plissart, M-F. 2003. Geographies of exclusion: Churches and child witches in Kinshasa. In People: A Magazine about a Certain Belgium 6, Pp. 46-58.

- 2004. Kinshasa: Tales of the invisible city. Royal Museum for Central Africa: Tervuren Ludion.

D’Haeyer, Aurore. 2004. Enfants sorciers, entre magie et misère. Bruxelles: Editions Labor.

Douglas, Mary. 1970. Introduction: Thirty years after Witchcraft, Oracles, and Magic. In Witchcraft confessions and accusations. Mary Douglas, ed. Pp. xiii-xxxviii. London: Tavistock Publications.

—. 1999. Sorcery accusation unleashed: The Lele revisited, 1987. Africa 69 (2): 177-193.

Evans, John F. 2014. Death-dealing witchcraft in the Bible? Notes on the condemnation of the "daughters' in Ezekiel 13: 17-23. Tyndale Bulletin 65 (1): 57-84.

Evans-Pritchard, Edward E. 1976. Witchcraft oracles and magic among the Azande. Oxford: Oxford University Press.

Foxcroft, Gary. 2007. Supporting victims of witchcraft abuse and street children in Nigeria. Paper to AFRUCA [Africans United Against Child Abuse].

- 2009. Witchcraft accusations: A protection concern for UNHCR and the wider humanitarian community? Stepping Stones Nigeria.

- 2014. Hunting witches. World Policy Journal 31(1): 9098.

Geschiere, Peter. 1980. Child witches against the authority of their elders. The Hague: Martinus Nijhoff.

- 1997. The modernity of witchcraft: Politics and the occult in postcolonial Africa. Charlottesville, VA: University of Virginia Press.

- 2013. Witchcraft, intimacy, and trust: Africa in Comparison. Chicago: The University of Chicago.

Girard, René. 2001. I see Satan fall like lightning. Maryknoll, NY: Orbis Books.

Hanson, Karl and Robert Ruggiero. 2013. Child witchcraft allegations and human rights. Brussels: European Parliament.

Harvey, Graham. 1995. The suffering of witches and children: Uses of witchcraft passages in the Bible. In Words Remembered, Texts Renewed: Essays in Honour of John F. A. Sawyer. Jon Davies, Wilfred G. E. Watson, and Graham Harvey, eds. Pp. 154-170. Library of Hebrew Bible/Old Testament Studies (195). Sheffield: Sheffield Academic Press.
Hayes, Stephen. 1995. Christian responses to witches and sorcery. Missionalia: The Journal of the Southern African Missiological Society 23 (3): 339-354.

Henningsen, Gustav. 1996. The child witch syndrome: Satanic child abuse of today and child witch trials of yesterday. Journal of Forensic Psychiatry and Psychology 7 (3): 581-593.

Hill, Frances. 1995. A delusion of Satan: The full story of the Salem witch trials. New York: De Capo Press.

Hill, Harriet. 2007. The effects of using local and non-local terms in mother-tongue Scripture. Missiology: An International Review 35 (4): 383-395.

- - 2003. Communicating context in Bible Translation among the Adioukrou of Côte d'Ivoire, Ph.D. dissertation, Fuller Seminary, Pasadena, CA.

Honigmann, John J. 1989. Subarctic: Kaska. In Witchcraft and sorcery of the American Native Peoples, Deward E. Walker, ed. Pp. 23-38. Moscow, ID: University of Idaho Press.

Human Rights Watch, 2006. What future? Street children in the Democratic Republic of Congo.

Kalonji Mbuyi, Jean Marie. 2003. La Sorcellerie Africaine, stratégie de délivrance. Kinshasa: Evangile de la Victoire.

- _ 2007. La racine du succès dans la délivrance de la sorcellerie. Kinshasa: Editions Evangile de la Victoire.

—_. 2010. Dieu et parents dans la lutte contre la sorcellerie en famille. Kinshasa: Editions Evangile de la Victoire.

—_. 2014. Enfants de la rue, causes profondes, Remèdes. Kinshasa: Evangile de la Victoire.

Kigalu Mangala, Jules. 2008. La Sorcellerie inconsciente éventrée. Kinshasa: Ecole de Délivrance. Volume I.

— - 2013. La Sorcellerie inconsciente éventrée. Kinshasa: Ecole de Délivrance. Volume II.

Kinyamba, S. Shemba, F. Muloka Nsenda, T. M. Kaminar, and W. Mbalanda. 2015. Monographie de la Ville de Kinshasa. Kinshasa, DRC: INCREDES.

Kitoko Bisimwa, Daisy. 2014. Le erreurs et les mystères dans le service de la délivrance. Kinshasa: Editions DKB Ministries.

Kunhiyop, Samuel W. 2002. Witchcraft: A philosophical and theological analysis. Africa Journal of Evangelical Theology 21(2): 127-145.

La Fontaine, Jean S. 2009. Child witches in London: Tradition and change in religious practice and belief. In The devil's children: From spirit possession to witchcraftNew allegations that affect children. Jean La Fontaine, ed. Pp. 117-128. Surrey, England: Ashgate Publishing Limited.

- 2016. Witches and demons: A comparative perspective on witchcraft and Satanism. The Pomegranate 18 (2): 245247.

- 2012. Problems of doing research at home. Research 
on child witches in London. Anthropology Today 28 (5):19-21.

Levack, Brian P. 2006a. ( $3^{\text {rd }}$ ed) The witch-hunt in early modern Europe. Harlow, UK: Pearson Education Limited.

. 2006b. Themes of recent witchcraft research. Arv: Nordic Yearbook of Folklore 62: 7-31.

Levi Strauss, Claude. 1963. The sorcerer and his magic. In Structural anthropology. Pp. 167-185. New York: Basic Books.

MacFarlane, Alan. 1970. Witchcraft in Tudor and Stuart England: A regional and comparative study. London: Routledge.

Madungu Tumwaka, P. (2002). La violence faite à l'enfant dit sorcier à Kinshasa. 11th Conference of AIDELF (Enfants d'aujourd'hui: Diversité des contextes, pluralité des parcours), Dakar, 10-13 December.

Marshall-Fratani, Ruth. 1998. Mediating the global and the local in Nigerian Pentecostalism. Journal of Religion in Africa 27 (3): 278-316.

Matangila, Alexis. 2006. Pour une analyse du discours des Eglises de réveil à Kinshasa. Méthode et contexte. Civilisations-Revue Internationale d'Anthropologie et de Sciences Humaines 54: 77-84.

Mayneri, Andrea Ceriana. 2017. "I went out into the street . . . and now I am fighting for my life": Street children, witchcraft accusations, and the collapse of the household in Bangui (Central African Republic). In Perspectives on African witchcraft. Mariano Pavanello, ed. Pp. 185-199. New York: Routledge.

Merz, Johannes. 2004. From relativism to imagination: Towards a reconstructive approach to the study of African witchcraft. Anthropos 99 (2): 572-580.

— 2008. "I am a witch in the Holy Spirit": Rupture and continuity of witchcraft beliefs in African Christianity. Missiology 36 (2): 201-218.

Meyer, Birgit. 1992. "If you are a devil, you are a witch and, if you are a witch, you are a devil": The integration of "pagan" ideas in the conceptual universe of the Ewe Christian in Southeastern Ghana. Journal of Religion in Africa 22 (2): 98-132.

—. 1995. "Delivered from the power of darkness": Confession of Satanic riches in Christian Ghana, Africa 65 (2): 236-255.

—. 1998a. Commodities and the power of prayers: Pentecostal attitudes towards consumption in contemporary Ghana. Development and Change 29 (4): 751-776.

- 1998b. The power of money: Politics, occult forces, and Pentecostalism in Ghana. Africa Studies Review 41 (3): 1537.

—. 1998c. "Make a complete break with the past": Time and modernity in Ghanaian Pentecostal discourse.' In Memory and the Postcolony. R.P. Werbner, ed. London
Zed Books.

1999a. Translating the Devil: Religion and modernity among the Ewe in Ghana. African World Press.

- 1999b. Commodities and the power of prayer: Pentecostalist attitudes towards consumption in contemporary Ghana. In Globalization and identity: Dialects of flow and closure. B. Meyer and P. Geschiere, eds. Oxford: Blackwell.

— . 2001. "You Devil, go away from me!" Pentecostal African Christianity and the power of good and evil. In Powers of good and evil: Transformation and popular belief. Paul Clough and Jon P. Mitchell, eds. Pp. 104-134. New York and Oxford: Berghahn Books.

Middleton, John. 1963. Witcheraft and sorcery in Lugbara. In Witchcraft and sorcery in East Africa. J. Middleton and E. H. Winter, eds. Pp 257-275. London: Routledge and Kegan Paul.

Molina, Javier Aguilar. 2005. The invention of child witches in the Democratic Republic of Congo: Social cleansing, religious commerce and the difficulties of being a parent in an urban culture. Summary of the research and experiences of Save the Children's 2003-2005 program funded by USAID.

Moscicke, Hans. 2017. Reconciling the supernatural worldviews of the Bible, African traditional religion, and African Christianity. Missionalia: Southern AfricanJournal of Mission Studies 45(2): 127-143.

Nida, Eugene A. (Interviewee) and David Neff (Interviewer). 2002. Meaning-full Translations. Christianity Today 46 (11): 46-49, October 7 .

Nwadinobi, Eleonor. 2008. The causes and prevalence of accusation of witchcraft among children in Akwa Ibom state. UNICEF, unpublished research paper.

Nyamnjoh, Francis B. Delusions of development and the enrichment of witchcraft discourses in Cameroon. In Magical Interpretations, material realities: Modernity, witchcraft and occult in postcolonial Africa. Henrietta L. Moore and Todd Sanders, eds. Pp. 28-49. New York, NY. Routledge.

Nzuzi Bibaki, P. 1997. Approches africaines de la Sorcellerie. Kinshasa: Editions Loyola.

Oien, Cecilie. 2006. Transnational networks of care: Angolan children in fosterage in Portugal. Ethnic and Racial Studies 29 (6): 1104-1117.

Onuzulike, Uchenna. 2013. Children accused of practicing witchcraft in Akwa Ibom, Nigeria: A qualitative analysis of online news media. International Journal of Child, Youth \& Family Studies 4(4): 447.

- 2014. Nollywood video film's impact on Nigerian and other African environments and cultures. Explorations in Media Ecology 13(3-4): 285-298.

. 2017. Review of witchcraft, witches and violence in Ghana by Mensah Adinkrah. African Studies Quarterly 17 (1): $107-108$. 
Onyinah, Opoku. 2001. Deliverance as a way of confronting witchcraft in modern Africa: Ghana as a case history. Cyberjournal for Pentecostal-Charismatic Research 10 (July).

—. 2004. Contemporary 'witch-demonology' in Africa. International Review of Mission 93 (3): 330-345.

—. 2012. Pentecostal exorcism: Witchcraft and demonology in Ghana. Dorset, UK: Deo Publishing.

Parrinder, Geoffrey. 1958. Witchcraft: A critical study of the belief in witchcraft from the records of witch hunting in Europe yesterday and Africa today. Penguin Books.

Pearson, David. 2009. The Christian church and child protection: An overview. In The Devil's children: From spirit possession to witchcraft-New allegations that affect children. Jean La Fontaine, ed. Pp. 189-195. Surrey, England: Ashgate Publishing Limited.

Pereira, Luena Nunes. 2011. Families, churches, the state and the child-witch in Angola. In Sorcery in the Black Atlantic. Louis Pares and Roger Sansi, eds. Pp. 187-208. Chicago: University of Chicago Press.

Pew Charitable Trusts. 2010. Tolerance and Tension: Islam and Christianity in Sub-Saharan Africa.

https://www.pewresearch.org/wpcontent/uploads/sites/7/2010/04/sub-saharan-africa-fullreport.pdf, Viewed Sept 30, 2019.

Phiri, Isaac. 2009. Saving witches in Kowezi: Accused of witchcraft by parents and churches, children in the Democratic Republic of Congo are being rescued by Christian activists. Christianity Today 53 (9): 62-65.

Pirot, B. 2004. Enfants des rues d'Afrique centrale: Douala et Kinshasa: De l'analyse à l'action. Paris: Karthala Editions.

Priest, Robert J. 2009. Witches and the problem of evil. Books and Culture: A Christian Review 15(6): 30-32.

—_. 2015a. Putting witch accusations on the missiological agenda: A case from Northern Peru. International Bulletin of Missionary Research 39: 3-6.

— $2015 \mathrm{~b}$. The value of anthropology for missiological engagements with context: The case of witch accusations. Missiology 43: 27-42.

Pull, Robert. 2009. Project Violet: Addressing the practice of faith and or belief based ritualistic related abuse of children. In The devil's children: From spirit possession to witchcraft: New allegations that affect children. Jean La Fontaine, ed. Pp. 179-188. Surrey, England: Ashgate Publishing Limited.

Pype, Katrien. 2012. The making of the Pentecostal melodrama: Religion, media, and gender in Kinshasa. New York: Berghahn.

Ranger, Terance. 2007. Scotland Yard in the bush: Medicine murders, child witches and the construction of the occulta literature review. Africa 77: 272-283.
Riedel, Felix. 2012. Children in African witch-hunts: An introduction for scientists and social workers. Witchcraft and Human Rights Information Network.

Rio, Knut. 2010. Handling sorcery in a state of law: magic, violence, and kastom in Vanuata. Oceania 80 (2): 182-197.

- 2014. A shared intentional space of witch-hunt and sacrifice. Ethnos 79(3): 320-341.

Rio, Knut, Michelle MacCarthy, and Ruy Blanes. 2017. Pentecostalism and witchcraft: Spiritual warfare in Africa and Melanesia. Springer 1-211.

Roper, Lyndal. 2000. Evil imaginings and fantasies: Childwitches and the end of the witch craze. Past and Present 167: 107-139.

Sansi, Roger. 2011. Sorcery and fetishism in the modern Atlantic. In Sorcery in the Black Atlantic. Louis Pares and Roger Sansi, eds. Pp. 19-39. Chicago: University of Chicago Press.

Santos-Granero, Fernando. 2002. Saint Christopher in the Amazon: Child sorcery, colonialism, and violence among the Southern Arawak. Ethnohistory 49 (3): 507-543.

- - 2004. The enemy within: Child sorcery, revolution, and the evils of modernization in eastern Peru. In In darkness and secrecy: The anthropology of assault sorcery and witchcraft in Amazonia. Neil L. Whitehead and Robin Wright, eds. Pp. 272-305. Durham, NC: Duke University Press.

Schmitt, Rudiger. 2012. Theories regarding witchcraft accusations and the Hebrew Bible. In Social theory and the study of Israelite religion: Essays in retrospect and prospect. Saul M. Olyan, ed. Pp. 181-194. Atlanta: Society of Biblical Literature.

Schnoebelen, Jill. 2009. Witchcraft allegations, refugee protection and human rights: A review of the evidence. UNHCR-The UN Refugee Agency.

Shweder, Richard. 2003. Why do men barbecue? Recipes for cultural psychology. Harvard University Press.

Snow, Steve. 2017. Explaining Abuse of "Child Witches" in Africa: Powerful Witchbusters in Weak States. Journal of Religion and Society 19:1-21.

Stabell, Timothy D. 2012. "The modernity of witchcraft" and the gospel in Africa. Missiology: An International Review 38(4): 460-474

Stobart, Eleanor. 2006. Child abuse linked to accusations of possession and witchcraft. Department for Education and Skills research report RR 750.

Tate, Tony and Karen Stauss. 2006. What future? Street children in the Democratic Republic of Congo. (Vol 18, No. 2). Human Rights Watch.

Tollens, Eic. 2003. Sécurité alimentaire à Kinshasa: Un face à face quotidien avec l'adversité. Kotholieke Universiteit 
Leuven, faculté des Sciences Agronomiques et de la Biologie Appliquée (Working Paper No. 77).

Tonda, Joseph. 2008. The violence of the imagination of children sorcerers. Cahiers d' Etudes Africaines 189-190: 325-343.

Turner, Victor. 1964. Witchcraft and sorcery: Taxonomy versus dynamics. Journal of the International African Institute 34 (4): 314-325.

Ugochukwu, Françoise. 2017. Changing Nigerian cultures: Two films against witchcraft and an impossible dialogue. Nigerian Film Culture and the Idea of the Nation: Nollywood and National Narration, James Tar Tsaaior \& Francoise Ugochukwu, eds. Pp. 73-92. London: Adonis and Abbey Publishers Ltd.

Van der Meer, Erwin. 2013. Child witch accusations in Southern Malawi. Australasian Review of African Studies 34(1): 129-144.

Wallo Mutsenga, Malochie. 2013. La Délivrance de la sorcellerie et ses envoûtements. Self-Published.

Wendland, Ernest R. 1992. Lexicography of the occult: Some problems of equivalence for Old Testament translators in Central Africa. Hupomenema (festschrift for J. P. Louw). Pp. 351-369. South Africa: University of Pretoria.

Whitehead, Neil L. and Robin Wright. eds., 2004. In darkness and secrecy: The anthropology of assault sorcery and witchcraft in Amazonia. Durham, NC: Duke University Press.

Wright, Robin. 2015. Assault Sorcery. Oxford Handbooks Online. Retrieved 12 June 2019, from

https://www.oxfordhandbooks.com/abstract/10.1093/oxfo rdhb/9780199935420.001.0001/oxfordhb9780199935420-e-28.

Yengo, Patrice. 2008. Le monde à l'envers. Enfance et kindoki ou les ruses de la raison sorcière dans le basin du Congo. Cahiers d'Études Africaines 48 (12), 189-190: 297-323.

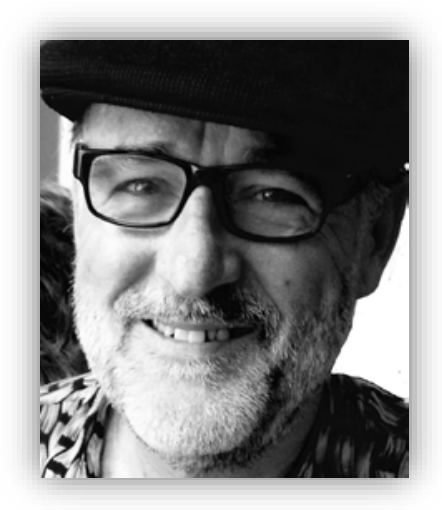

Robert J. Priest is Professor of Anthropology at Taylor University. He has served as president of both the American Society of Missiology (2013-14) and the Evangelical Missiological Society (2015-17). For a decade he directed the Ph.D. Program in Intercultural Studies at Trinity Evangelical Divinity School. While at Trinity, he served as the primary dissertation supervisor for 36 Ph.D. students. His research and writing have included a focus on the anthropology of religion, race and ethnicity, sexuality and marriage, short-term missions, religious conversion, contextualization, missiology as a field, and witcheraft accusations. On occasion, he has coordinated teams of senior scholars working together on specific research and writing projects, such as in the Africa Leadership Study (2008-2018), where results were published in a 2019 book co-edited by Robert Priest and Kirimi Barine: African Christian Leadership: Realities, Opportunities, and Impact (Orbis/Langham).

Author email: robert_priest@taylor.edu

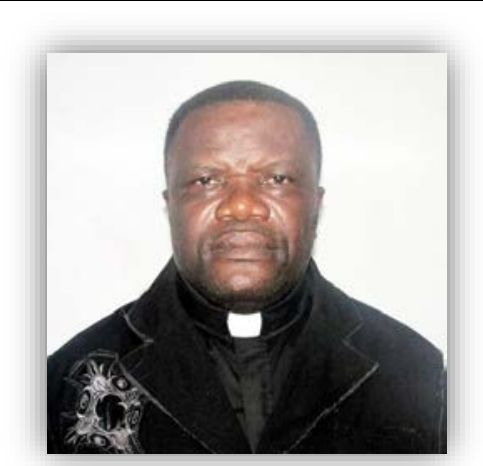

Abel Ngolo was born on May 25, 1961 in Bandundu in the Democratic Republic of Congo, Abel Ngolo is a theologian, statistician-economist. Married and father of eight children, he is a consecrated pastor of the church within the Baptist Community of the Congo River (CBFC) in Kinshasa. In 1999, he 
founded the association "Pastoral team for children in distress," with the acronym EPED, whose mission is the protection and security of children of which he is currently Chairman of the Board of Directors.

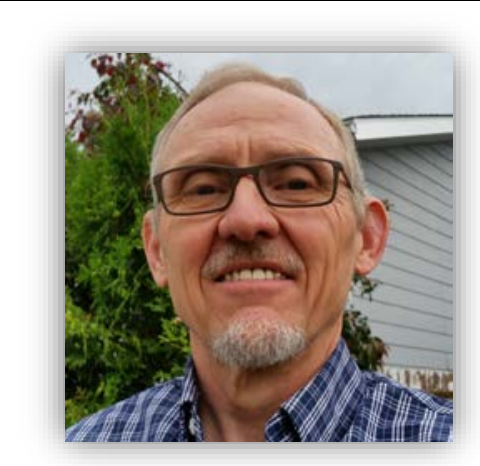

Timothy Stabell grew up in the Democratic Republic of Congo (DRC-former Zaire) as the son of American Baptist missionaries. He has a BA in sociology from Eastern College (now Eastern University), an MA in sociology from the New School for Social Research, and an MAR in theology from Westminster Seminary. He and his wife Susan served in the DRC with Africa Inland Mission from 1981 to 1996. After those years, Tim did his Ph.D. in Intercultural Studies at Trinity Evangelical Divinity School, writing his dissertation on "'The Modernity of Witchcraft' and Theological Contextualization in Contemporary Africa." From 2005 to 2015 he taught at Briercrest College and Seminary, where he was coordinator of the Intercultural Studies program. Since then he has served as pastor of the Prairie Winds Church, a Mennonite Brethren congregation located in Moose Jaw, Saskatchewan. Ever since 2003, Tim has returned to northeastern Congo for a month or two most years to teach at Shalom University of Bunia. Tim and Susan have four married children and seven grandchildren.

Author email: tsstabell@aimint.org 